\title{
Engineering of staphylococcal surfaces for biotechnological applications
}

Henrik Wernérus

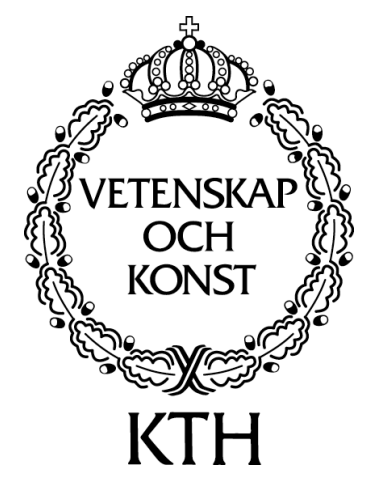

Royal Institute of Technology

Department of Biotechnology

Stockholm 2002 


\section{(C) Henrik Wernérus}

Department of Biotechnology

Royal Institute of Technology

AlbaNova University Center

SE-106 91 Stockholm

Sweden

Printed at Universitetsservice US AB

Box 70014

10044 Stockholm

Sweden

ISBN 91-7283-386-6 
Henrik Wernérus (2002): Engineering of staphylococcal surfaces for biotechnological applications. Department of Biotechnology, Royal Institute of Technology, Stockholm, Sweden.

ISBN 91-7283-386-6

\begin{abstract}
The engineering of bacterial surfaces has in recent years attracted a lot of attention with applications in many different areas of bioscience. Here we describe the use of two different surface display systems for the gram-positive bacteria Staphylococcus carnosus and Staphylococcus xylosus in various biotechnological applications.
\end{abstract}

Environmental microbiology currently attracts a lot of attention since genetically engineered plants and bacteria might be used as bioadsorbents for sequestration of toxic metals. Bacterial surface display of metal-binding peptides might enable recycling of the biomass by desorption of accumulated heavymetals. In an attempt to recruit staphylococcal display systems for bioremediation purposes, polyhistidyl peptides were successfullly displayed on the surface of recombinant $S$. carnosus and $S$. xylosus cells. Whole-cell $\mathrm{Ni}^{2+}$-binding assays demonstrated that the recombinant cells had gained metal-binding capacity compared to wild-type cells.

Tailor-made, metal-binding staphylococci was created using a previously constructed phage-display combinatorial protein library based on a fungal cellulose-binding domain (CBD) derived from the cellobiohydrolase Cel7A of Trichoderma reseii. Novel metal-binding CBDs were generated through a phage mediated selection procedure. Selected CBD variants, now devoid of cellulose binding, were randomly selected and sequence analysis of selected variants revealed a marked preference for histidine residues at the randomized positions. Surface display of these novel CBD variants resulted in recombinant staphylococci with increased metal-binding capacity compared to control strains, indicating that this could become a general strategy to engineer bacteria for improved binding to specific metal ions.

Directed immobilization of cells with surface displayed heterologous proteins have widespread use in modern biotechnology. Among other things they could provide a convenient way of generating biofilters, biocatalysts or whole-cell diagnostic devices. It was therefore investigated whether directed immobilization of recombinant staphylococci on cotton fibers could be achieved by functional display of a fungal cellulose-binding domain (CBD). Recombinant $S$. carnosus cells with surface anchored CBDs from Trichoderma reseii Cel6A were found to efficiently bind to cotton fibers creating almost a monolayer on the fibrous support. The co-expression of this CBD together with previously described metal-binding proteins on the surface of our staphylococci would create means for developing effective bioadsorbents for remediation purposes.

The original plasmid vector, designed for heterologous surface display on recombinant S. carnosus cells has exhibited problems related to structural instability, possibly due to the presence of a phage f1 origin of replication in the vector sequence. This would be a problem if using the vector system for library display applications. Therefore, novel surface display vectors, lacking the phage ori were constructed and evaluated by enzymatic and flow cytometric whole-cell assays. One such novel vector, pSCX $m$, exhibited dramatically increased plasmid stability with the retained high surface density of expressed heterologous proteins characteristic for the original S. carnosus display vector, thus making it potentially more suitable for library display applications.

The successful engineering of our staphylococcal display system encouraged us to further evaluate the potential to use the staphylococcal system for display of combinatorial protein libraries and subsequent affinity based selections using flow cytometric cell sorting. A model system of recombinant $S$. carnosus cells with surface displayed engineered protein A domains was constructed. It was demonstrated that target cells could be sorted essentially quantitatively from a moderate excess of background cells in a single sorting-step. Furthermore, the possibility of using staphylococcal surface display and flow cytometric cell sorting also for specific enrichment of very rare target cells by multiple rounds of cell-sorting and in between amplification was demonstrated.

Key words: affibody, albumin binding protein, bacterial surface display, cell immobilization, bioremediation, combinatorial protein engineering, flow cytometry, Gram-positive, metal binding, staphylococcal protein A, Staphylococcus carnosus, Staphylococcus xylosus, whole-cell devices

(C) Henrik Wernérus, 2002 

"Tag vara på ditt liv! Akta det väl! Slarva inte bort det! För nu är det din stund på jorden!"

Vilhelm Moberg 



\section{LIST OF PUBLICATIONS}

This thesis is based on the following papers, which in the text will be referred to by their Roman numerals:

I. Samuelson, P., Wernérus, H., Svedberg, M. and Ståhl, S. Staphylococcal surface display of metal-binding polyhistidyl peptides. Appl.Environ. Microbiol. (2000) 66:1243-1248.

II. Lehtiö, J., Wernérus, H., Samuelson, P., Teeri, T. and Ståhl, S. Directed immobilization of recombinant staphylococci on cotton fibers by functional display of a fungal cellulose-binding domain. FEMS Microbiol. Lett. (2001) 195:197-204.

III. Wernérus, H., Lehtiö, J., Teeri, T., Nygren, P-Å. and Ståhl, S. Generation of metal-binding staphylococci through surface display of engineered cellulose-binding domains. Appl. Environ. Microbiol. (2001) 67: 4678-4684.

IV. Wernérus, H. and Ståhl, S. Vector engineering to improve a staphylococcal surface display system. FEMS Microbiol. Lett. (2002) 212: $47-54$.

V. Wernérus, H., Samuelson, P. and Ståhl, S. Fluorescence activated cell sorting of specific affibody-displaying staphylococci. Manuscript. (2002). 



\section{Table of contents}

\section{Introduction}

1. Surface display systems for bacteria ........................................................1

1.1 Surface display systems for Gram-negative bacteria........................................................... 1

1.2 Surface display systems for Gram-positive bacteria................................................................ 6

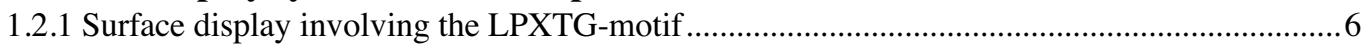

1.2.2 Other display systems for Gram-positive bacteria..............................................................

2. Applications for bacterial surface display .......................................................9

2.1 Vaccine delivery vehicles ...................................................................................................................... 9

2.2 Display of antibody fragments and other binding proteins .......................................... 13

2.3 Surface display for whole cell biocatalysis ................................................................................ 14

2.4 Combinatorial protein engineering ....................................................................................... 16

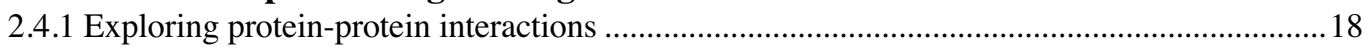

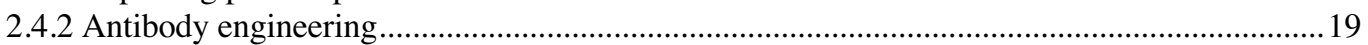

2.4.3 Engineering of enzyme activity and specificity …………............................................... 19

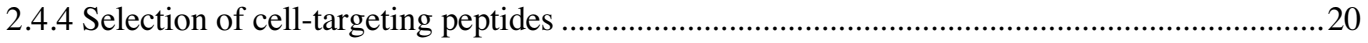

2.4.5 Selection of novel metal-binding peptides .........................................................................2

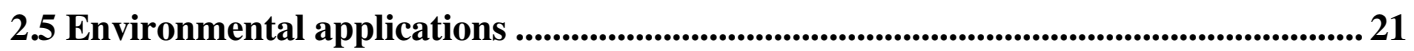

2.5.1 Surface display of metallothioneins and phytochelatins on bacteria .....................................22

2.5.2 Surface display of short metal-binding histidine rich peptides ..........................................23

2.5.3 Surface display of tailor-made metal-binding proteins .....................................................24

3. Staphylococcal surface display and its applications ....................................25

3.1 Staphylococcal surface display vectors ...................................................................................... 27

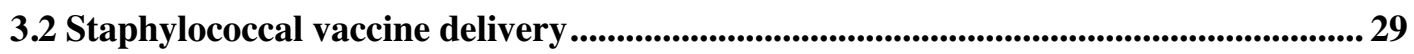

3.3 Microbial biocatalysis through enzyme display ....................................................... 31

3.4 Binding proteins for diagnostic applications ......................................................................... 31

Present Investigation

4. Generation of metal-binding staphylococci (I, III) ...........................................33

4.1 Surface display of polyhistidyl peptides (I) ………….............................................................. 33

4.2 Tailor-made metal-binding staphylococci (III) ................................................................... 37

5. Directed immobilization of recombinant staphylococci (II) ............................39

6. Second generation display vectors for $S$. carnosus (IV) ..................................... 42

7. Staphylococcal surface display for selection purposes (V) ................................45

8. Future perspectives and concluding remarks ....................................................49

9. Abbreviations .....................................................................................51

10. Acknowledgements .................................................................................52

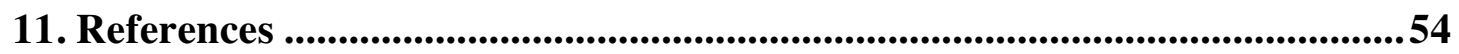





\section{Introduction}

Proteins are naturally displayed on bacterial surfaces in order to interact with substances located in the surrounding environment. These proteins have a wide range of functions important for binding to host tissues or to specific immune system components, the uptake of nutrients, protein processing or the interbacterial aggregation for the conjugal transfer of DNA. The concept to use naturally occuring surface protein as a mechanism for targeting foreign molecules to bacterial surfaces has resulted in a broad range of interesting applications in many different areas of bioscience.

This thesis will focus mainly on various biotechnological applications of cell surface display, rather than being an indepth analysis of different molecular mechanisms used for targeting heterologous proteins to the bacterial cell surface. For a more comprehensive summary of different systems used for expression of chimeric proteins on bacterial surfaces the interested reader are encouraged to read the article by Samuelson and co-workers (Samuelson et al., 2002).

\section{Surface display systems for bacteria}

The display of heterologous proteins on bacterial surfaces has been an area of intense research since the first reports of this novel technology were published in 1986 by Freudl and co-workers and Charbit and co-workers, respectively (Charbit et al., 1986; Freudl et al., 1986). A wide range of different methods for targeting heterologous proteins to the cell surface exist, and this section will give an introduction to some of the more important systems. Although not included here, it should be mentioned that also yeast (Wittrup, 2001), mammalian (Whitehorn et al., 1995), and insect cells (Ernst et al., 1998) have been used with great success for cell surface display applications. These systems are particularly well suited for expression of eukaryotic proteins in need of extensive post translational modifications that cannot be performed in prokaryotes.

\subsection{Surface display systems for Gram-negative bacteria}

Surface display of heterologous proteins is usually achieved through a translational fusion of your target protein to one of the naturally occuring surface proteins of the host cell. The cell surface of Gram-negative bacteria is host to a multitude of 
functionally and structurally diverse proteins involved in for example, cell motility, adhesion and chemotaxis. Many of these naturally occuring surface proteins have been extensively investigated for surface display applications and described in more detail elsewhere (Georgiou et al., 1997; Benhar, 2001; Samuelson et al., 2002). This section will give a brief introduction to some of the more frequently used systems for targeting heterologous proteins to the surface of Gram-negative bacteria. For a summary see Table 1 .

(i) Outer membrane proteins

So far, the most frequently used systems for expression of heterologous proteins on the surface of Gram-negative bacteria are based on outer membrane proteins (OMPs) (Koebnik et al., 2000; Lång, 2000). The OMPs form a distinct group of integral membrane proteins with the common structural motif of a $\beta$-barrel that is composed of a variable number of transmembrane $\beta$-strands connected on the periplasmic side with short turns and on the outside with long surface accessible loops (Stathopoulos, 1999). Outer membrane proteins generally occur as monomers, like OmpA, or assembled into trimers like the porin family, including for example $\mathrm{OmpC}$, $\mathrm{PhoE}$ and LamB. The rapid development within the field of bacterial surface display was spurred by the first successful report of the genetic insertion of a gene fragment encoding 15 amino acids, into the fourth outer loop of the Escherichia coli ompA gene (Freudl et al., 1986). This clearly demonstrated that foreign peptides could be inserted into the loops of outer membrane proteins in a functional and surface accessible form. Also other OMPs were probed for the potential use as surface display vehicles. Surface exposed loops of the maltoporin LamB were used as the insertion point of an 11 amino acid epitope from the VP1 coat protein of type 1 poliovirus (Charbit et al., 1986). The fusion protein was correctly targeted and expressed at the cell surface and shown to recognize epitope specific antibodies in both immunofluorescence and immunogold microscopic analysis. Since then, many different OMPs have been used for the display of peptides on bacterial surfaces, including OprF (Wong et al., 1995), PhoE (Agterberg et al., 1990), OmpS (Lång and Korhonen, 1997), OmpC (Xu and Lee, 1999). 
Table 1: Selected examples where Gram-negative bacteria have been used for surface display applications.

\begin{tabular}{|c|c|c|}
\hline Display system & Displayed protein & References \\
\hline \multicolumn{3}{|c|}{ Outer membrane proteins } \\
\hline OmpA & $\begin{array}{l}\text { Peptides } \\
\text { Malarial antigens } \\
\text { Peptides }\end{array}$ & $\begin{array}{l}\text { Freudl et al., } 1986 \\
\text { Haddad et al., } 1995 \\
\text { Mejáre et al., } 1998\end{array}$ \\
\hline LamB & $\begin{array}{l}\text { C3 epitope of poliovirus } \\
\text { Peptide library } \\
\text { Peptides }\end{array}$ & $\begin{array}{l}\text { Charbit et al., } 1986 \\
\text { Brown, } 1997 \\
\text { Kotrba et al., 1999a }\end{array}$ \\
\hline OprF & Malaria epitope & Wong et al., 1995 \\
\hline PhoE & Part of FMDV & Agterberg et al., 1987 \\
\hline OmpS & Epitopes & Lång et al., 1997 \\
\hline OmpC & $(\mathrm{His})_{162}$ & Xu et al., 1999 \\
\hline FhuA & T7-tag, myc-epitope & Etz et al., 2001 \\
\hline BtuB & T7-tag, myc epitope & Etz et al., 2001 \\
\hline Lpp'OmpA & $\begin{array}{l}\text { GFP } \\
\text { Phytochelatins } \\
\beta \text {-lactamase } \\
\text { PhoA }\end{array}$ & $\begin{array}{l}\text { Shi et al., } 2001 \\
\text { Bae et al., } 2000 \\
\text { Francisco et al., } 1992 \\
\text { Stathopoulos et al., } 1996\end{array}$ \\
\hline Invasin & Peptide libraries & Nakajima et al., 2000 \\
\hline EaeA Intimin & Epitope mapping & Christmann et al., 2001 \\
\hline Inp & $\begin{array}{l}\text { CMCase } \\
\text { Salmobin } \\
\text { OPH } \\
\text { CMCase } \\
\text { OPH (library) }\end{array}$ & $\begin{array}{l}\text { Jung et al., } 1998 \\
\text { Jeong et al., } 2001 \\
\text { Shimazu et al., } 2001 \\
\text { Kim et al., } 2000 \\
\text { Cho et al., } 2002\end{array}$ \\
\hline \multicolumn{3}{|c|}{ Autotransporters } \\
\hline $\operatorname{Ig} \mathrm{A}_{\beta}$ & $\begin{array}{l}\text { CTB } \\
\mathrm{MT}\end{array}$ & $\begin{array}{l}\text { Klauser et al., } 1990 ; 1992 \\
\text { Valls et al., } 2000\end{array}$ \\
\hline AIDA-I & $\begin{array}{l}\text { CTB \& peptide antigen } \\
\beta \text {-lactamase }\end{array}$ & $\begin{array}{l}\text { Maurer et al., } 1997 \\
\text { Lattemann et al., } 2000\end{array}$ \\
\hline $\operatorname{Ag} 43$ & FimH lectin domain & Kjaergaard et al., 2001 \\
\hline MisL & Malaria epitope & Ruiz-Perez et al., 2002 \\
\hline \multicolumn{3}{|c|}{ Extracellular appendages } \\
\hline Fimbriae & $\begin{array}{l}\text { Peptide libraries } \\
\text { Peptide libraries }\end{array}$ & $\begin{array}{l}\text { Schembri et al., } 1999 \\
\text { Kjaergaard et al., } 2001\end{array}$ \\
\hline Flagella & $\begin{array}{l}\text { Peptide libraries } \\
\text { Peptide libraries }\end{array}$ & $\begin{array}{l}\text { Lu et al., } 1995 \\
\text { Brown et al., } 2000\end{array}$ \\
\hline \multicolumn{3}{|l|}{ Other systems } \\
\hline PAL & Antibody fragments & Fuchs et al., 1991 \\
\hline TraT & Poliovirus epitope & Harrison et al., 1990 \\
\hline Pullulanse & $\beta$-lactamase & Kornacker et al., 1990 \\
\hline
\end{tabular}


However, the concept of introducing foreign peptides into extracellular loops often impose severe size constraints on the displayed moieties (Charbit et al., 1988). One of the more size permissable systems developed for Gram-negative bacteria is the Lpp'OmpA hybrid system (Francisco et al., 1992). It consists of the leader peptide and the first nine amino acids of the major E. coli lipoprotein (Lpp) fused to five of the seven membrane spanning regions of OmpA. This system has been extensively used for the display of enzymes, $\mathrm{scFv}$ antibody fragments and other binding domains on E. coli (Georgiou et al., 1997). However, a disadvantage of the system is its sensitivity to extensive secondary and tertiary structures of the passenger (Stathopoulos et al., 1996).

The ice-nucleation protein (Inp) (Wobler, 1993), an outer membrane protein from Pseudomonas syringae capable of inducing ice-crystal formation in supercooled water, has recently attracted a lot of attention as a potent surface display anchoring motif (Jung et al., 1998; Bassi et al., 2000; Kim et al., 2000; Shimazu et al., 2001; Wang et al., 2002). It consists of an N-terminal region interacting with the phospholipid moiety of the outer membrane, a central repeat region involved in icenucleation and a C-terminal highly hydrophilic region exposed to the cell surface. Foreign proteins expressed as a fusion to the C-terminus will be efficiently displayed on the cell surface with retained ice-nucleation activity.

\section{(ii) Autotransporters}

Members of the immunoglobulin A1 protease-like autotransporter family is an alternative route for the efficient secretion and surface display of heterologous proteins in Gram-negative bacteria (Klauser et al., 1993; Henderson et al., 1998; Henderson et al., 2000). The autotransporter proteins are generally characterized by the feature that all information required for transport to the outer membrane and secretion through the cell envelope is contained within the protein itself, without the need for accessory proteins. Although the quite diverse activities of autotransporters they exhibit a general structure consisting of an $\mathrm{N}$-terminal leader sequence, a passenger domain encompassing the protein to be secreted and finally a C-terminal autotransporter domain that mediates the transport of the passenger domain through the outer membrane (Henderson et al., 1998). A number of different autotransporters have been investigated for the display of heterologous proteins on bacteria including 
the $\beta$-domain of the $\operatorname{IgA}_{1}$ protease of Neisseria gonorrhoeae (Klauser et al., 1990; Klauser et al., 1992; Valls et al., 2000b), the E. coli adhesin involved in diffuse adherence (AIDA-I) (Maurer et al., 1997; Konieczny et al., 2000; Lattemann et al., 2000), Ag43 (Kjaergaard et al., 2002), and a protein of membrane insertion and secretion (MisL), from Salmonella enterica (Ruiz-Perez et al., 2002). These systems seem to be well suited for translocation of large passenger proteins, due to the Cterminal fusion strategy, however, the apparent incompatibility for translocation of passenger domains containing extensive tertiary structure such as disulfide bonds (Klauser et al., 1990) might be a limiting factor.

(iii) Fimbriae/Flagella

The third method of choice for heterologous display on Gram-negative bacteria is the use of highly polymeric surface organelles like fimbriae, or flagella as scaffolds for surface presentation (Klemm and Schembri, 2000b). Fimbriae are adhesive surface organelles which enable bacteria to target and colonize specific host tissues. A large variety of fimbrial proteins have been used for surface display including the FimA and FimH proteins of type 1 fimbriae (Hedegaard and Klemm, 1989; Kjaergaard et al., 2001), the FelA subunit of type P fimbriae (van Die et al., 1990), and the major structural subunit of type 4 fimbriae to name a few (Jennings et al., 1989). Fimbriae proteins are present at extremely high numbers on the cell surface which make them attractive for display purposes, however the major structural proteins of various fimbriae can only accommodate relatively small inserts (10-30 aa) without disturbing the organelle structure and surface display efficiency (Klemm and Schembri, 2000a). Flagella are extracellular filamentous structures involved in cell motility (WesterlundWikström, 2000). Flagella display is based on the genetic fusion of foreign peptides into the surface exposed nonessential central region of flagellin, the flagellar major subunit present in thousands of copies per filament. This approach has been successfully used for expression of foreign peptides/proteins to be displayed on flagella (Kuwajima, 1988). A versatile variant of flagellar display is the hybrid display system created by the insertion of the entire gene encoding E. coli thioredoxin into the central region of flagellin. Peptide libraries has been genetically introduced into a disulfide loop of thioredoxin creating a conformationally constrained library readily accessible on the flagellar surface. This so called FLITRX-system has been 
used with great success for epitope mapping purposes (Lu et al., 1995; Tripp et al., 2001).

\subsection{Surface display systems for Gram-positive bacteria}

Gram-positive bacteria are morphologically simple cells consisting of three distinct cellular compartments: the cytosol, a single cytoplasmic membrane, and a thick peptidoglycan cell-wall. In addition, some sporulating species, such as Bacillus subtilis, synthesize a large polysaccharide capsule surrounding the cell. Due to the thick cell-wall, surface proteins of Gram-positive bacteria are not membrane spanning but covalently linked to the peptidoglycan cell wall (Navarre and Schneewind, 1999). Gram-positive bacteria are attractive for surface display applications due to their robust nature and $\mathrm{C}$-terminal anchoring of surface proteins, making the functional display of also large proteins possible (Kelemen and Sharpe, 1979). Extensive structural studies of surface proteins in different species have revealed a common cell-wall anchoring motif among a large group of Gram-positive bacteria. The Cterminal anchoring tail consists of approximately 35 amino acids, including a conserved LPXTG-motif followed by a stretch of hydrophobic amino acids and a short charged tail at the extreme C-terminus (Fischetti et al., 1990; Schneewind et al., 1995). The mechanism for cell-wall sorting and anchoring have been elucidated and is known to involve a proteolytic cleavage between the threonine and glycine residues followed by covalent linkage of the C-terminus to a free amino group of the peptide cross-bridge in the peptidoglycan (Navarre and Schneewind, 1994; Ton-That et al., 2000). The enzyme responsible for this process in Staphylococcus aureus has been identified and named sortase (Mazmanian et al., 1999). This principle for surface anchoring has allowed surface exposure of large polypeptides on Gram-positive bacteria by fusion of the target gene between the N-terminal secretion signal and the C-terminal anchoring sequence of naturally occuring surface proteins (Table 2.).

\subsubsection{Surface display involving the LPXTG-motif}

The cell-wall anchoring region from staphylococcal protein A (SpA) has been successfully used to create plasmid shuttle vectors for surface display of heterologous proteins on recombinant Staphylococcus xylosus (Hansson et al., 1992), Staphylococcus carnosus (Samuelson et al., 1995) and Lactococcus lactis (Steidler et al., 1998). This strategy has been used for the display of target proteins of various 
lengths, ranging from 15 to 397 amino acids. The display of heterologous proteins on food-grade recombinant staphylococci will be thoroughly covered in section 3 .

The $\mathrm{M}$ proteins are dimeric $\alpha$-helical fibrillar proteins found on the surface of groupA streptococci. They are generally considered to have anti-phagocytic properties and all members of the M-family possess the characteristic $\mathrm{N}$-terminal leader sequence and a typical C-terminal sorting signal (Navarre and Schneewind, 1999). The M6protein of Streptococcus pyogenes has been functionally expressed on the surface of Streptococcus gordonii using a chromosomal integration strategy instead of the commonly employed plasmid vector approach (Pozzi et al., 1992). Subsequently, this concept have been successfully used for surface presentation of a wide range of different immunogens on recombinant $S$. gordonii (Oggioni et al., 1999). In related studies, it was shown that the M6 protein of S. pyogenes is indeed expressed and cell wall anchored also in various lactic acid bacteria (Piard et al., 1997). These findings lead to the construction of an efficient cell-wall targeting system for Lactococccus lactis using the M6 anchoring motif (Dieye et al., 2001). This system have been used for the development of a food-grade, live vaccine delivery system for heterologous antigens (Ribeiro et al., 2002).

Strauss and Götz utilized the C-terminal anchoring region of S. aureus fibronectin binding protein $\mathrm{B}$ (FnBPB) to achieve proper cell wall anchoring of recombinant proteins in S. carnosus (Strauss and Götz, 1996).

Recently, Lee and co-workers demonstrated the possibility of using the major surface protein antigen P1 (SpaP1) originating from Streptococcus mutans to achieve surface localization of heterologous proteins (Lee et al., 1999). Foreign epitopes have been introduced into the middle part of SpaP1 generating vectors suitable for oral vaccine delivery (Lee et al., 2002).

\subsubsection{Other display systems for Gram-positive bacteria}

No surface proteins containing cell-wall sorting signals have been isolated among the sporulating genera of Bacillus. Still, the vegetative form of B. subtilis has been used to target foreign antigens to the bacterial surface as fusions to the B. subtilis cell-wall autolysin modifier protein CwbA (Acheson et al., 1997). In a later study, a display system based on Bacillus spores was developed (Isticato et al., 2001). A protein of the 
B. subtilis spore coat, CotB (Donovan et al., 1987), was found to be located on the spore surface and used as a fusion partner to express heterologous antigens in a functional and surface accessible form (Isticato et al., 2001). The high stability, combined with cost efficient large scale production, makes bacterial spores an attractive alternative for heterologous surface expression. Furthermore, the CotB system has been used to display heterologous proteins up to $52 \mathrm{kDa}$, suggesting that it may exhibit less size restrictions than other cell-based systems (Isticato et al., 2001). Also Bacillus anthracis, the causal agent of anthrax, have been used for surface display applications by chromosomal integration of a translational fusion between the surface layer protein EA1 and heterologous antigens (Mesnage et al., 1999). Finally, using a membrane associated lipoprotein from Mycobacterium tuberculosis, an outer surface protein A (OspA) antigen from Borrelia burgdorferi could be displayed on the surface of recombinant Mycobacterium bovis (Stover et al., 1993).

Table 2: Selected examples where Gram-positive bacteria have been used for surface display applications.

\begin{tabular}{lll}
\hline Display system & Displayed protein & References \\
\hline Protein A & scFv fragment & Gunneriusson et al., 1996 \\
& RSV G protein & Cano et al., 2000 \\
& IgA and IgE specific affibodies & Gunneriusson et al.,1999 \\
& Polyhistidyl peptides & I \\
& Streptavidin & Steidler et al., 1998 \\
FnBPB & Staphyloccocus hyicus lipase, $\beta$-lactamase & Strauss and Götz, 1986 \\
M6 & E7 protein of human papillomavirus & Pozzi et al., 1992 \\
& White-faced hornet antigen & Medaglini et al., 1995 \\
& Tetanus toxin fragment C (ToxC) & Medaglini et al., 2001 \\
SpaP1 & Staphylococcal nuclease & Dieye et al., 2001 \\
& Bordella pertussis S1 subunit & Lee et al., 1999 \\
CwbA & Lee et al., 2002 \\
CotB & Yersinia pseudotuberculosis invasin & Acheson et al., 1997 \\
Mtb19 & Tetanus toxin & Isticato et al., 2001 \\
SLH & OspA lipoprotein from B. burgdorferi & Stover et al., 1993 \\
\hline
\end{tabular}




\section{Applications for bacterial surface display}

Initial research within the field of bacterial surface display was focused mainly on the development of vaccine delivery vehicles but during the last decade the field has gained a lot of interest as this type of research holds great promise for a wide range of applications in both immunology, applied microbiology and biotechnology. This section will give an introduction to some of the different areas in which surface display of heterologous proteins have been investigated for biotech applications (Figure 1).

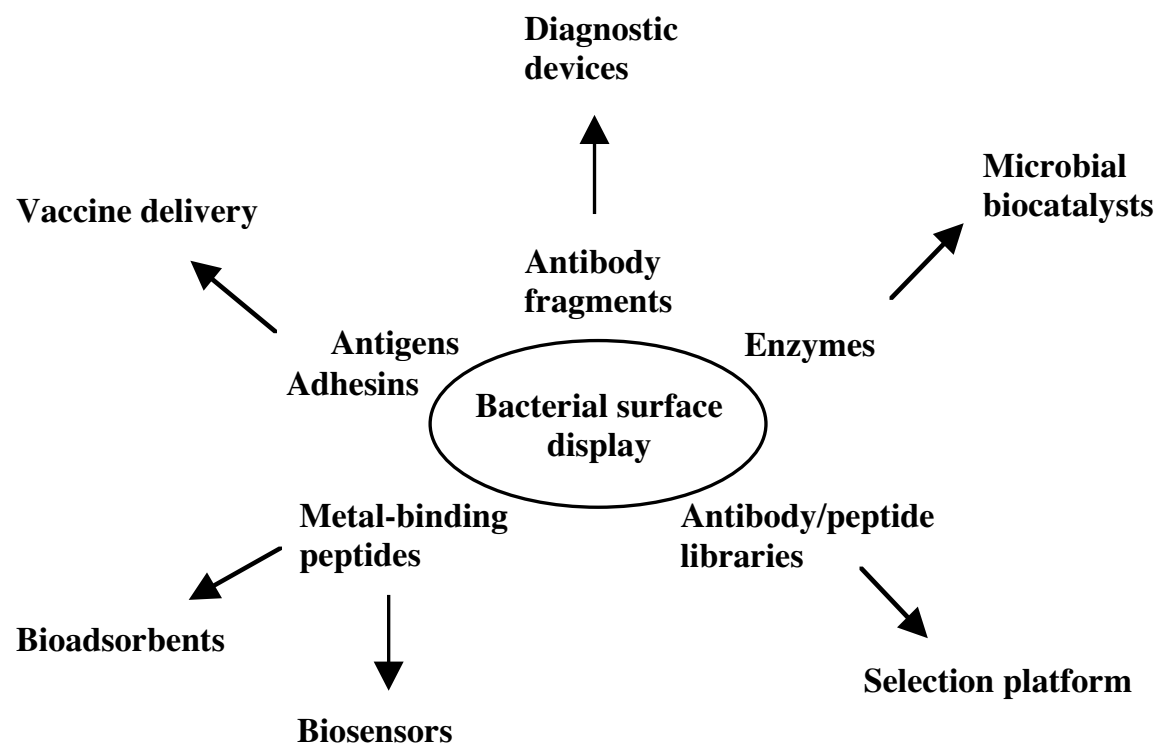

Figure 1. Some examples of surface displayed proteins and possible application areas for such recombinant bacteria.

\subsection{Vaccine delivery vehicles}

Traditionally, the most common application area for bacterial surface display has been in the development of live vaccine-delivery systems for mucosal immunizations. Perhaps the most important advantage of using mucosal strategies for immunizations, compared to traditional parenteral administration is the capacity to induce a local immune response leading to production of antigen specific secretory IgA. This is important since many bacterial and viral infections are aquired through mucosal membranes of the respiratory and intestinal tract, and also since the induction of a local secretory $\operatorname{IgA}$ response is a main mediator of local protection. Two different strategies have been used to generate live bacterial vaccines. Either attenuated 
variants of normally pathogenic bacteria such as Gram-negative Salmonella spp (Dertzbaugh, 1998) and the Gram-positive M. bovis strain BCG (Stover et al., 1993), or alternatively non-pathogenic commensal or food-grade bacteria, such as $S$. gordonii and different staphylococcal and lactic acid bacteria have been used. (Fischetti et al., 1996; Ståhl et al., 1997). In recent years, the concern over safety aspects when using live attenuated pathogens in children, the elderly and individuals with partially impaired immune function has lead to an increasing interest in the use of non-pathogenic commensal and food-grade bacteria as vaccine delivery vehicles (Mekalanos, 1994). In this context, it has generally been considered advantageous with cell surface display of the heterologous antigen to elicit an antigen specific immune response (Haddad et al., 1995; Nguyen et al., 1995; Ståhl et al., 1997). Also, the co-expression of either surface exposed adhesins that will assist in targeting the antigen to the mucosal epithelium, or immunomodulating molecules, has greatly improved the immune response evoked by such recombinant bacteria (Cano et al., 2000; Maggi et al., 2002).

The use of Gram-positive commensal or food-grade bacteria as vaccine delivery vehicles for oral or intranasal administration is attractive for several reasons. They are generally regarded as safe for human use, inexpensive, easy to administer and capable of inducing both a local secretory IgA response at the site of pathogen entry and a systemic immune response (Wells and Pozzi, 1997). Below, a few selected examples are described where engineered bacteria with surface exposed heterologous antigens have been used for subunit vaccine delivery. A more extensive overview can be found in Table 3.

Initial attempts to use commensal or food-grade bacteria as vaccine delivery vehicles for mucosal immunizations generally resulted in rather low and highly variable antibody responses (Ståhl et al., 1997; Liljeqvist and Ståhl, 1999). Strategies to improve the immune response evoked by such vaccines have recently been described, and involves the co-display of either immunomodulating molecules or adhesins that will assist in targeting the antigen to the mucosa (Cano et al., 2000; Maggi et al., 2002). The Gram-positive bacterium $S$. gordonii was recently used for simultaneous expression of the immunomodulating B monomer of E. coli heat-labile toxin (LTB) and the V3 domain of HIV-1 gp120, at the bacterial surface. The resulting V3-specific 
IgG response was four-fold higher in mice immunized with this strain than for control animals inoculated with $S$. gordonii expressing the V3 domain alone (Maggi et al., 2002). Similar results have been achieved also for staphylococcal vaccine vectors. By co-expression of a colera toxine B (CTB) epitope together with peptides derived from the G glycoprotein of human respiratory cyncytial virus (RSV), protective immunity to RSV challenge in mice was reported (Cano et al., 2000).

A candidate Lyme disease vaccine, was developed by expressing the B. burgdorferi outer surface protein A (OspA) lipoprotein on the recombinant bacille CalmetteGuérin (BCG) (Stover et al., 1993; Langermann et al., 1994). The recombinant BCG OspA vaccine was shown to be safe and immunogenic in several animal models, and protective in a mouse model of Lyme borreliosis (Langermann et al., 1994). However, in recent phase I clinical trials designed to determine the feasibility of using recombinant $\mathrm{BCG}$ as a live bacterial vaccine vector also in humans, no primary immune response was detected against the model antigen (Edelman et al., 1999).

One important aspect when constructing bacterial based vaccine delivery vehicles is their capacity to withstand the harsh conditions that can be expected during vaccine storage and transportation. In this context, spore based vaccines that are resistant to heat and cold, might be an attractive alternative. In a pioneering study (Acheson et al., 1997), highly immunogenic domains of the Yersinia pseudotuberculosis invasin protein (Inv) (Leong et al., 1990) was expressed as a fusion to the cell-wall bound autolysin modifier protein $\mathrm{CwbA}$ in the vegetative form of the spore-forming organism B. subtilis. Upon oral immunization of mice with spores encoding this fusion protein, a systemic immune response was elicited, indicating that the administered spores must have germinated in the mouse gastrointestinal tract in order to present the engineered protein to the immune system (Acheson et al., 1997). Attempts have also been made to express the $\mathrm{C}$-terminal fragment of the tetanus toxin (TTFC) directly on the spore surface by fusion to CotB, a protein of the B. subtilis spore coat (Isticato et al., 2001). The immunogenicity of the recombinant spores in mice suggested that TTFC was expressed in a biologically active form on the spore surface. 
Table 3: Selected examples where live bacteria with surface displayed antigens have been used as vaccine delivery vehicles.

\begin{tabular}{|c|c|c|c|c|c|}
\hline $\begin{array}{l}\text { Display } \\
\text { system }\end{array}$ & Organism & $\begin{array}{l}\text { Displayed } \\
\text { antigen }\end{array}$ & $\begin{array}{l}\text { Animal } \\
\text { model }\end{array}$ & Results & Reference \\
\hline \multicolumn{6}{|l|}{ Gram-negative } \\
\hline MisL & S.typhimurium & Malarial (NANP) & Mice & Ag. specific IgG & $\begin{array}{l}\text { Ruiz-Perez et } \\
\text { al., } 2002\end{array}$ \\
\hline Inp & S. typhi Тy21a & $\mathrm{HCV}, \mathrm{HbsAg}$ & $\begin{array}{l}\text { Mice (i.n. } \\
\text { and i.p.) }\end{array}$ & $\begin{array}{l}\text { Ag. specific IgG } \\
+ \text { partial protection }\end{array}$ & $\begin{array}{l}\text { Lee et al., } \\
2000\end{array}$ \\
\hline \multirow[t]{2}{*}{ LamB } & E. coli & HbsAg (preS2) & $\begin{array}{l}\text { Mice and rabbits } \\
\text { (i.v.) }\end{array}$ & Ag. specific IgG & $\begin{array}{l}\text { Charbit et al., } \\
1987\end{array}$ \\
\hline & E. coli & Polio epitope (C3) & Mice (i.p.) & $\begin{array}{l}\text { Ag. specific IgG } \\
\& \text { IgM }\end{array}$ & $\begin{array}{l}\text { Leclerc et al., } \\
1991\end{array}$ \\
\hline OmpA & S.typhimurium & $\begin{array}{l}\text { Malarial epitopes } \\
\text { (SERP, HRPII) }\end{array}$ & Mice (orally) & $\begin{array}{l}\text { Ag. specific IgG } \\
\text { and IgM }\end{array}$ & $\begin{array}{l}\text { Schorr et al., } \\
1991\end{array}$ \\
\hline Chimeric OmpA & S.typhimurium & $\begin{array}{l}\text { Malarial epitope } \\
\text { (M3) }\end{array}$ & Mice (i.p) & Ag. specific IgG & $\begin{array}{l}\text { Haddad et al., } \\
1995\end{array}$ \\
\hline \multicolumn{6}{|l|}{ Gram-positive } \\
\hline \multirow[t]{3}{*}{$\mathrm{SpA}$} & S.xylosus & RSV antigen & Mice (orally) & Ag. specific IgG & $\begin{array}{l}\text { Nguyen et al., } \\
1993\end{array}$ \\
\hline & S. carnosus & $\mathrm{SpG} / \mathrm{CTB}$ & Mice (i.n.) & $\begin{array}{l}\text { Ag. specific IgG } \\
\text { and IgA }\end{array}$ & $\begin{array}{l}\text { Cano et al., } \\
1999\end{array}$ \\
\hline & S. carnosus & CTB/RSV & Mice (i.n.) & Protection & $\begin{array}{l}\text { Cano et al., } \\
2000\end{array}$ \\
\hline \multirow[t]{3}{*}{ M6 } & S. gordonii & $\begin{array}{l}\text { Ag5.2 (allergen } \\
\text { from white face } \\
\text { hornet venom) }\end{array}$ & $\begin{array}{l}\text { Mice (orally } \\
\text { and i.n.) }\end{array}$ & $\begin{array}{l}\text { Ag. specific IgG } \\
\text { and } \operatorname{sg} A\end{array}$ & $\begin{array}{l}\text { Medaglini et } \\
\text { al., } 1995\end{array}$ \\
\hline & & TTFC & $\begin{array}{l}\text { Mice (i.n. } \\
\text { and subcut.) }\end{array}$ & Protection & $\begin{array}{l}\text { Medaglini et } \\
\text { al., } 2001\end{array}$ \\
\hline & & $\begin{array}{l}\text { LTB and HIV1 } \\
\text { epitope V3 }\end{array}$ & Mice (subcut.) & Ag. specific IgG & $\begin{array}{l}\text { Maggi et al., } \\
2002\end{array}$ \\
\hline \multirow[t]{2}{*}{ SpaP1 } & S. gordonii & $\begin{array}{l}\text { Pertussis toxin } \\
\text { subunit S1 }\end{array}$ & Mice (i.p.) & Protection & $\begin{array}{l}\text { Lee et al., } \\
1999\end{array}$ \\
\hline & & $\begin{array}{l}\text { Pertussis toxin } \\
\text { subunit } \mathrm{S} 1\end{array}$ & Mice (orally) & Ag. specific sIgA & $\begin{array}{l}\text { Lee et al., } \\
2002\end{array}$ \\
\hline SLH & B. anthracis & TTFC & Mice (subcut.) & Protection & $\begin{array}{l}\text { Mesnage et } \\
\text { al., } 1999\end{array}$ \\
\hline $\operatorname{Cot} B$ & B. subtilis & TTFC & Mice (subcut.) & Ag specific IgG & $\begin{array}{l}\text { Isticato et al., } \\
2001\end{array}$ \\
\hline \multirow[t]{2}{*}{$\begin{array}{l}\text { Lipoprotein } \\
\text { Mtb19 }\end{array}$} & M. bovis-BCG & $\begin{array}{l}\text { OspA from } \\
\text { B. burgdorferi }\end{array}$ & Mice (i.n.) & $\begin{array}{l}\text { Ag specific IgG } \\
\text { and } \operatorname{sIg} A\end{array}$ & $\begin{array}{l}\text { Langermann et } \\
\text { al., } 1994\end{array}$ \\
\hline & & $\begin{array}{l}\text { OspA from } \\
\text { B. burgdorferi }\end{array}$ & Human (i.d.) & $\begin{array}{l}\text { No detectable Ag. } \\
\text { specific IgG }\end{array}$ & $\begin{array}{l}\text { Edelman et al., } \\
1999\end{array}$ \\
\hline
\end{tabular}




\subsection{Display of antibody fragments and other binding proteins}

Recombinant bacteria expressing single chain ( $\mathrm{scFv}$ ) antibody fragments linked to the outer cell membrane could potentially be used in bacterial based solid-phase immunoassays. This would be an easy and cost efficient alternative to the present use of hybridoma cell lines for production of monoclonal antibodies. This idea was pioneered by Fuchs and co-workers who used an N-terminal fusion to the E. coli peptidoglycan associated lipoprotein PAL for successful surface display of functional scFv molecules (Fuchs et al., 1991). Since then, several other reports have been made on the generation of such whole-cell monoclonals expressing recombinant antibodies at the cell surface (Francisco et al., 1993a; Gunneriusson et al., 1996; Bassi et al., 2000). The practical implications of this technology was demonstrated by the development of a quantitative whole-cell immunoassay utilizing E. coli cells with surface expressed scFv fragments (Chen et al., 1996). The assay was reported to be quick and accurate down to the nanomolar level. This type of bacteria expressing recombinant antibodies or other tailor-made binding molecules could also be used in immunoprecipitation experiments or as whole cell bioadsorbents for purification of immunologically important proteins. Alternatively, surface expression of specific binding proteins might improve vaccine delivery vectors by targeting them to specific immunoreactive sites (Maggi et al., 2002; Liljeqvist et al., 1999).

Furthermore, in a different approach the possibility of using recombinant bacteria with surface displayed peptide epitopes as whole-cell bioadsorbents for affinity purification of monospecific antibodies was recently demonstrated by Christmann and co-workers (Christmann et al., 2001). A linear peptide epitope from the classical swine fever virus (CSFV) was displayed on $E$. coli cells as a fusion to a carboxyterminally truncated intimin, an adhesin from enteropathogenic E. coli. These epitope-presenting cells were used as whole cell adsorbents for isolating monospecific antibodies from a polyclonal serum, claiming that a $100 \mathrm{ml}$ liquid culture should be sufficient for immobilization of at least $1 \mathrm{mg}$ of antibodies (Christmann et al., 2001; Wentzel et al., 2001). This type of affinity isolated monospecific antibodies could become useful as immunochemicals for various applications, like immunoblotting, immunocytochemistry and flow cytometric analysis as well as providing an attractive alternative to the rather costly and time consuming generation of monoclonal antibodies. 


\subsection{Surface display for whole cell biocatalysis}

The targeting of biologically active proteins to bacterial surfaces create potential applications for biomedical and biotechnological use. The traditional way of performing an enzymatic reaction involves the use of purified, free or immobilized enzyme. One concern is the cost for enzyme production and purification. Immobilization is a strategy for more efficient use of the enzyme. However, the immobilization step might lead to changes in enzyme activity and stability (Scouten, 1995). A more cost-efficient alternative would be to use whole cells expressing the enzyme of interest as a cell bioreactor. However, this approach suffers from mass transport limitations since the outer cell membrane act as a permeability barrier preventing substrates from interacting with the enzymes within the cell. An elegant solution to this problem would be to express the active enzyme on the bacterial surface, thus creating a cost efficient system without the need for enzyme purification and eliminating the mass transport problems associated with intracellular expression.

In two pioneering studies, E. coli $\beta$-lactamase normally located in the periplasmic space, was expressed with retained enzymatic activity on the surface of E. coli using the pullulanase system (Kornacker and Pugsley, 1990) and the Lpp'OmpA-system, respectively (Francisco et al., 1992). Since then, several other enzymes have been sucessfully displayed on bacteria using a wide range of different expression systems (Table 4). However, not all enzymes can be exposed on the cell surface of Gramnegative bacteria, exemplified by alkaline phosphatase for which inefficient exposure was reported when using the Lpp'OmpA system (Stathopoulos et al., 1996).

A recent example of the practical importance of this type of whole-cell biocatalysts is the genetically engineered $E$. coli strain co-displaying a cellulose-binding domain and organophosphorous hydrolase exhibiting both specific adhesion to cellulose as well as hydrolysis of organophosphorous nerve agents (Wang et al., 2002). Bacterial cells immobilized on a cellulose matrix efficiently degraded organophosphorous nerve agents and retained almost $100 \%$ efficiency over a period of 45 days. This type of system could become an attractive alternative for large-scale detoxification of organophosphorous nerve agents. In a similar study, recombinant staphylococci with surface displayed fungal cellulose binding domains have been created and shown to efficiently adhere to cotton fibers (II). The co-expression of biologically active 
substances as a fusion to this CBD might become useful for biocatalytic applications and a more detailed description will follow in the present investigation section 5 .

Active enzymes have also been expressed on the surface of Gram-positive bacteria (Strauss and Götz, 1996). Due to their robust nature, Gram-positive bacteria might be an attractive alternative to Gram-negative bacteria as whole-cell biocatalysts (Strauss and Götz, 1996). Another potential advantage is that there is only need for translocation through one membrane to achieve secretion and surface exposure, in contrast to the two membranes present in Gram-negative bacteria.

Furthermore, cell surface display of enzyme libraries for selective screening of novel variants with improved kinetics (Kim et al., 2000) or altered substrate specificity has recently been demonstrated (Olsen et al., 2000b). Also, by sequential cycles of DNA shuffling and screening of the surface displayed organophosphorous hydrolase (OPH) library, novel variants exhibiting improved hydrolysis of organophosphate nerve agents were isolated and characterised in a solid-phase format (Cho et al., 2002). For more information related to this type of applications, see section 2.4.3.

Table 4: Selected examples of functionally active enzymes displayed on bacteria

\begin{tabular}{lll}
\hline Display system & Displayed protein & References \\
\hline Gram-negative & & \\
Pullulanase & $\beta$-lactamase & Kornacker et al., 1990 \\
Lpp'OmpA & $\beta$-lactamase & Francisco et al., 1992 \\
Lpp'OmpA & Cellulomonas fimi exoglucanase (Cex) & Francisco et al., 1993b \\
Inp & Zymomonas mobilis levansucrase (LevU) & Jung et al., 1998 \\
Inp & B. subtilis CMCase & Jung et al., 1998 \\
AIDA-I & $\beta$-lactamase & Lattemann et al., 2000 \\
Inp & Organophosphorous hydrolase (OPH) & Shimazu et al., 2001 \\
Inp & Salmobin & Jeong et al., 2001 \\
Inp \& Lpp'OmpA & OPH \& CBD & Wang et al., 2002 \\
Gram-positive & & \\
FnBPB & S. hyicus lipase \& $\beta$-lactamase & Strauss and Götz, 1996 \\
\hline
\end{tabular}




\subsection{Combinatorial protein engineering}

The emergence of phage display technology and the rapid development of novel methods for creating genetic diversity have lead to recent advances within the field of combinatorial protein engineering. Today there exists a broad range of different technology platforms generating the necessary genotype-phenotype linkage for combinatorial library applications. Since its invention almost two decades ago phage display has become the most common method for display of combinatorial libraries for selection purposes (Smith, 1985), but more recently also other methods based on bacterial surface display (Daugherty et al., 1999), yeast display (Wittrup, 2001), and ribosomal display (Hanes and Pluckthun, 1997) have emerged as attractive alternatives to the established phage display methodology (Smith and Petrenko, 1997). This section will focus on advances in bacterial display of combinatorial libraries for selection purposes. The question of how to choose a suitable platform for library display is ultimately decided by the needs of the protein to be displayed. For expression of eukaryotic proteins in need of extensive postranslational modifications, yeast might be preferred over bacteria (Wittrup, 2001). The combination of flow cytometry (Figure A) and cell display provides a powerful method for rapid and efficient screening of combinatorial libraries for selection of novel variants with improved affinity, stability, enzymatic activity or altered substrate specificity (Georgiou, 2001). The bacterial cell provides a tight genotype-phenotype linkage while the flow cytometer enables quantitative analysis of ligand binding and surface expression over several orders of magnitude. Current state of the art cell sorters can accurately analyse 50000 cells per second enabling a rapid and extensive screen of typical sized combinatorial libraries (Wittrup, 2001). This gives bacterial display a competitive advantage over the traditional phage display technology since phages are too small to be sorted on a flow cytometer (Georgiou, 2001). Bacterial display of combinatorial libraries has an advantage for affinity selections since they by design are free of avidity effects resulting in false positives in the selection procedure. This can be attributed to the fact that analyzis of roughly 10000-100000 proteins molecules per cell eliminates the stochastic uncertainties inherent in scaffolds displaying only a few protein molecules, exemplified by the common fusions to phage protein III (Lowman et al., 1991). Also, cell display combined with flow cytometry offers the possibility of quantitative determination of binding kinetics in situ 


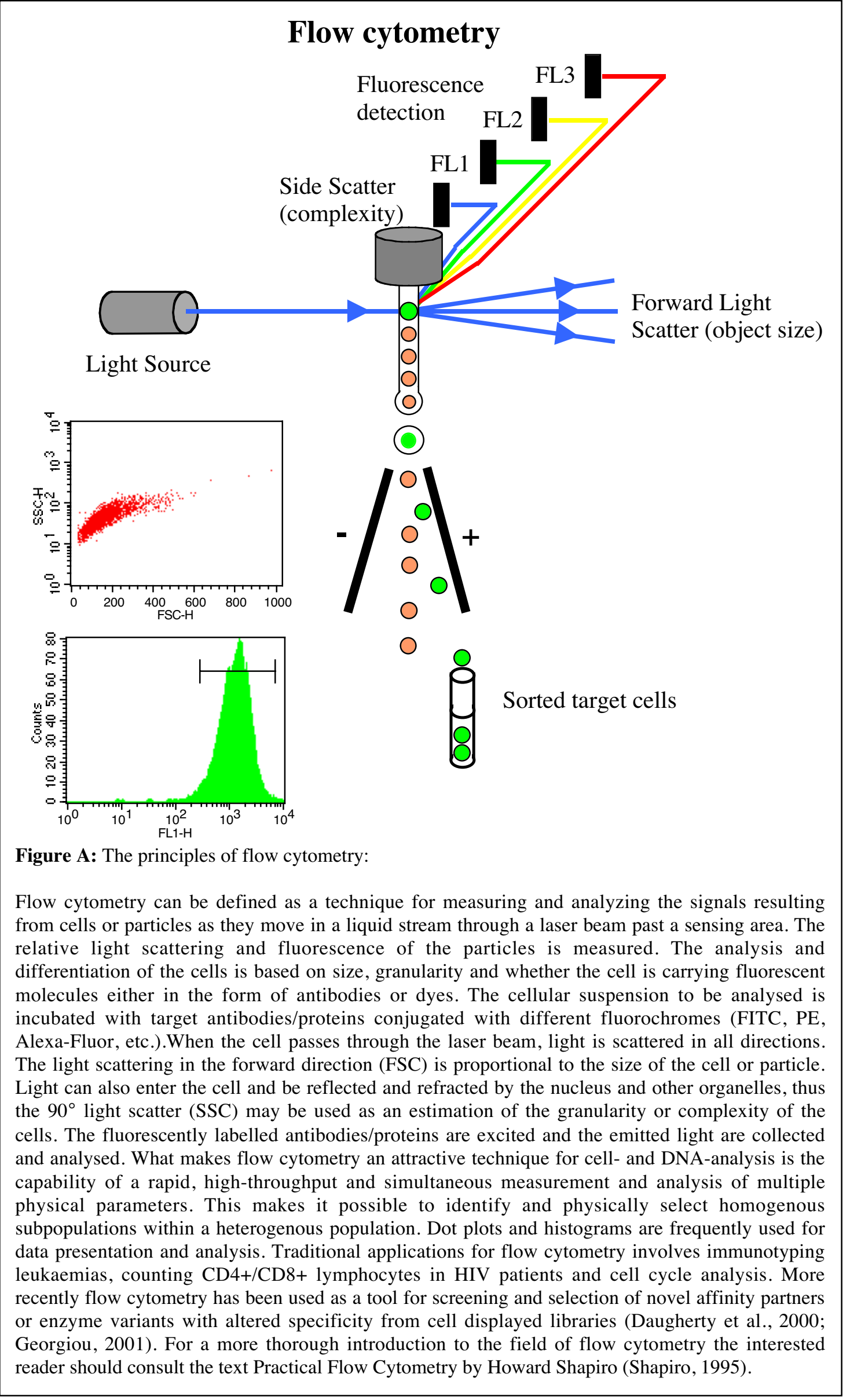


(Boder and Wittrup, 2000). The obvious bottle neck when using cell display methods for library selections is the limited transformation frequencies that can be obtained compared to cell-free in vitro techniques like ribosomal display or covalent display methods (Dower and Mattheakis, 2002). So far, bacterial surface display of combinatorial libraries have been used for, among other things; epitope mapping, antibody affinity maturation, enzyme engineering, selection of peptides conferring entry into mammalian cells, and the generation of bacteria with increased affinity towards metals for use as bioadsorbents. The following sections will present selected examples of this technology, for more extensive coverage the reader are advised to read the comprehensive reviews by (Boder and Wittrup, 2000; Georgiou, 2001; Wittrup, 2001; Chen and Georgiou, 2002).

\subsubsection{Exploring protein-protein interactions}

The use of peptide libraries as a tool for identifying antigenic regions on proteins is well established. Phage display of random peptide libraries has been extensively used for epitope mapping (Smith and Petrenko, 1997) but it is only recently that also other microorganisms and eucaryotic cells have been used for the same purposes. The earliest example of using also bacterial display systems for protein-protein interaction studies and epitope mapping is the FLITRX system described by Lu and co-workers (Lu et al., 1995). A random dodecapeptide library was displayed in the thioredoxin active-site loop, inserted in the dispensible region of the flagellin gene, the major structural component of the E. coli flagellum. This system was sucessfully used to map three different antibody epitopes using a panning technique on an immobilized target. As an alternative to using synthetic random peptide libraries, a target gene can be enzymatically digested and expressed to form a phage library suitable for epitope mapping (Pereboeva et al., 2000; Holzem et al., 2001). Christmann and co-workers recently described a system for precise mapping of linear epitopes utilizing a carboxyterminally truncated intimin, an adhesin from enteropathogenic E. coli, as a carrier protein to present foreign peptides on the bacterial surface (Christmann et al., 2001). A random library of gene fragments derived from the classical swine fever virus (CSFV) envelope protein $\mathrm{E}^{\text {rns }}$ was generated by DNAse I cleavage and displayed on the bacterial surface. Using a polyclonal anti- $E^{\text {rns }}$ serum together with flow cytometric cell sorting it was possible to isolate a major linear antigenic determinant of the $\mathrm{E}^{\text {rns }}$ protein. 


\subsubsection{Antibody engineering}

The first successful attempt to combine bacterial display and flow cytometric cell sorting for affinity based selection of proteins with specific binding properties was published in 1993 by Franscisco and co-workers (Francisco et al., 1993a). Utilizing fluorescence activated cell sorting technology they were able to specifically enrich cells displaying scFv-antibodies using the Lpp'OmpA system from a $10^{5}$-fold excess of controll cells not expressing scFvs on the cell surface (Francisco et al., 1993a). In addition, Fuchs and co-workers demonstrated the potential to discriminate between cells displaying different $\mathrm{scFv}$ antibodies, using fluorescently labeled antigens and FACS (Fuchs et al., 1996). Also yeast cells have been successfully used in this context (Schreuder et al., 1996). Since then, flow cytometry has been frequently used for screening of whole protein libraries displayed on the surface of bacteria or yeast (Georgiou, 2001; Wittrup, 2001). The isolation of high affinity scFv antibodies (Daugherty et al., 1998; Boder et al., 2000), single chain T cell receptors and protease inhibitors from libraries screened by flow cytometry has been reported (Christmann et al., 1999; Holler et al., 2000).

\subsubsection{Engineering of enzyme activity and specificity}

Recently, the display of large libraries of engineered enzymes on the surface of recombinant bacteria have been used to select for novel variants exhibiting improved catalytic activity (Kim et al., 2000) or altered substrate specificity (Olsen et al., 2000b). Kim and co-workers were able to set up a selective screen for novel variants of a carboxymethyl cellulase (CMCase) showing improved catalytic activity. A library of mutated CMCase genes were created by DNA shuffling (Stemmer, 1994a; Stemmer, 1994b) and expressed as a fusion to the ice nucleation protein (Inp) from Pseudomonas syringae for efficient display on E. coli cells (Kim et al., 2000). The library was screened for improved growth rates on carboxymethyl agar plates and improved CMCase variants with a 5-fold increase in activity could be isolated. In a different approach Olsen and co-workers recently described a method for flourescence activated cell-sorting of surface displayed enzyme libraries for selection of novel enzyme variants with altered substrate specificities (Olsen et al., 2000b). Flow cytometry has in fact been used for several years for the analysis of enzyme activity and kinetics at the single cell level (Watson and Dive, 1994), but until now it has not been adapted as a screening tool for directed enzyme evolution mainly due to 
difficulties in designing enzyme substrates for flow cytometry applications. This was solved by taking advantage of the highly negatively charged cell wall of Gramnegative bacteria and designing a fluorescence resonance energy transfer (FRET) substrate with a polycationic tail that adsorbs to the bacterial surface. By expressing a random library of the serine protease OmpT at the bacterial surface and by using a FRET peptide substrate with a nonpreferred Arg-Val cleavage sequence novel protease variants with a 60-fold increase in catalytic activity could be isolated (Olsen et al., 2000a).

\subsubsection{Selection of cell-targeting peptides}

In recent years there has been a growing interest in developing selection methods for cell-binding peptides (Barry et al., 1996; de Boer et al., 1996). This is due to the fact that this type of cell-specific peptides could provide means for targeting other bioactive agents, such as drugs, to particular cells in vivo. Until now phage display has been the preferred technique but recently the first report of the utilization of a bacterial invasion system to screen for ligands binding to mammalian cells was published (Nakajima et al., 2000). An expression system for the display of random peptides on the cell surface of $E$. coli was created by replacing the carboxyterminal end of the invasin protein (Bliska and Falkow, 1984) from Yersinia pseudotuberculosis with random peptides. This cell surface protein of $Y$. pseudotuberculosis mediates entry of the bacterium into non-phagocytic mammalian cells in its native state. The resulting surface displayed random decamer peptide library, was systematically screened for its binding affinity towards human cultured cells, and several bacterial clones were identified whose binding to human cells were mediated by peptides expressed at the bacterial surface (Nakajima et al., 2000). In a similar study (Taschner et al., 2002), a fibronectin binding motif of the fibronectinbinding protein $(\mathrm{FnBPa})$ of $S$. aureus was inserted in the E. coli outer membrane protein FhuA (Etz et al., 2001). The surface displayed fibronectin binding motifs were shown to mediate entry of the bacteria into non phagocytic eucaryotic cells with the preferential selection of these cells over E. coli expressing parental FhuA (Taschner et al., 2002). These examples suggests that bacterial surface display might indeed be a powerful method for the selection of novel peptide entry motifs. 


\subsubsection{Selection of novel metal-binding peptides}

Novel metal-binding peptides and proteins selected by phage display technology, have been expressed on bacterial surfaces to create bacteria with increased affinity towards heavy metal contaminants (Mejáre et al., 1998; III). An alternative route for the creation of such tailor-made bacteria would be to display peptide/protein libraries directly on bacteria to perform the biopanning in a whole cell format. This was demonstrated by Brown and co-workers who used the E. coli outer membrane protein LamB for display of a random polypeptide library. Using this strategy it was possible to isolate peptide fragment conferring binding to iron oxide, gold and chromium (Brown, 1997). Other studies, using the FimH adhesin of E. coli type 1 fimbriae for display of peptide libraries have been presented and novel $\mathrm{Zn}^{2+}$-chelating peptides have been isolated (Schembri et al., 1999; Kjaergaard et al., 2001). This type of novel metal binding peptides could be used in the development of biosensors or to create whole cell bioadsorbents for bioremediation purposes.

\subsection{Environmental applications}

The increasing accumulation of heavy-metal contaminants in our environment due to agricultural and industrial applications is a growing concern for public health. Conventional methods for remediation of contaminated sites like precipitationfiltration, ion-exchange, oxidation-reduction and membrane separation often fail to reduce the heavy-metal contaminants to acceptable levels. Therefore, there exists a growing need for alternative methods capable of removing heavy-metal contaminants. Recent efforts have focused on the development of bioadsorbents with increased affinity and selectivity for the target metals. The use of non-engineered and recombinant bacteria for heavy-metal removal is currently attracting a lot of attention (Mullen et al., 1989). Higher organisms like plants and animals generally respond to heavy-metal challenge by production of cysteine-rich peptides like metallothioneins (MTs) and phytochelatins (PCs) (Stillman et al., 1992; Rauser, 1995) that bind metal ions and sequester them in biologically inactive forms (Stillman et al., 1992). This was utilized by Pazirandeh and co-workers by overexpressing a Neurospora crassa MT in E. coli thereby generating a bacteria that were superior to wild-type cells in terms of metal ion adsorption (Pazirandeh et al., 1995; Pazirandeh, 1996). Also other metal-binding peptides have been intracellularly and periplasmically produced to create bacteria with improved metalloadsorption characteristics (Pazirandeh et al., 
1998). However, the intracellular expression of eucaryotic metallothioneins and phytochelatins in E. coli is not trivial (Valls et al., 1998). This is likely due to the difficulties in producing cystein-rich proteins in a functional form intracellularly in bacteria. Also, on more practical grounds, intracellular expression of MTs or PCs may prevent the recycling of the biomass by desorption of accumulated heavy-metals. It has therefore been suggested that surface display of the metal-binding peptides/proteins might be beneficial if the bacteria are to be used as bioadsorbents in the purification of contaminated soil and industrial wastewater. The following sections will feature selected examples in which metal-binding peptides and proteins have been surface expressed on bacteria for bioremediation purposes, see also Table 5 for a summary.

Table 5: Selected examples where metal-binding peptides and proteins have been expressed on the surface of bacteria for environmental applications.

\begin{tabular}{llll}
\hline Display system & Displayed protein & Strain & References \\
\hline Lpp'OmpA & MT & E. coli & Valls et al., 1998 \\
LamB & MT (Mammalian/yeast & E. coli & Sousa et al., 1998 \\
LamB & MT ( $\alpha$-domain) & E. coli & Kotrba et al., 1999b \\
IgA $\beta$ & MT (mouse) & Pseudomonas putida & Valls et al., 2000b \\
Lpp'OmpA & PC (synthetic) & E. coli & Bae et al., 2000 \\
Inp & PC (synthetic) & Moraxella sp. & Bae et al., 2002 \\
SpA & $(\text { His })_{6}$ & $S$. carnosus $/$ S. xylosus & (I) \\
LamB & $(\text { His })_{6}$ & E. coli & Sousa et al., 1996 \\
OmpC & $(\text { His })_{12}$ & E. coli & Xu et al., 1999 \\
LamB & HP/CP & E. coli & Kotrba et al., 1999a \\
OmpA & His-Ser-Gln-Lys-Val-Phe & E: coli & Mejáre et al., 1998 \\
SpA & Engineered CBD & $S$. carnosus & (III) \\
FimH & Peptide library & E. coli & Kjaergaard et al, 2001 \\
\hline Abbreviating
\end{tabular}

Abbreviations: MT, metallothionein; $\mathrm{PC}$, phytochelatin; HP, histidine containing peptide; $\mathrm{CP}$, cysteine containing peptide; $\mathrm{CBD}$, cellulose binding domain.

\subsubsection{Surface display of metallothioneins and phytochelatins on bacteria}

There have been several reports on surface display of yeast and mammalian metallothioneins (MTs) in recombinant E. coli cells (Sousa et al., 1998; Valls et al., 1998; Kotrba et al., 1999b). Sousa and co-workers reported on a 15-20 fold increase in Cd-accumulation for $E$. coli cells displaying yeast (CUP1) and mammalian (HMT- 
1A) MTs anchored to the outer membrane protein LamB (Sousa et al., 1998) and similar reports have been published by others (Valls et al., 1998; Kotrba et al., 1999b). The use of lab-born E. coli strains might however not be suitable for in-situ soil remediation and other more suitable strains have therefore been investigated (Valls et al., 2000a; Valls et al., 2000b). Pseudomonas is a highly robust microorganism able to grow also in highly contaminated areas and might therefore be a better choice for bioremediation applications. The expression of a fusion chimera between a mouse MT and the beta-domain of the IgA protease of Neisseria in the outer membrane of Pseudomonas putida cells resulted in a three-fold increase in metal-binding capacity (Valls et al., 2000b). Recent efforts have also been made to create bacteria with surface exposed synthetic phytochelatins (PCs) (Bae et al., 2000; Bae et al., 2002). Phytochelatins are naturally occuring metal-binding peptides found in plants and fungi (Rauser, 1995) with the general structure (Glu-Cys) Gly (n=2-11). They generally have a higher metal-binding capacity than MTs and might therefore be better suited for bioadsorption applications (Bae et al., 2000) which was demonstrated by the cell surface display of synthetic PCs on Moraxella sp. by fusion to the ice nucleation protein generating recombinant strains with a ten-fold increase in mercurybinding capacity compared to wild-type cells (Bae et al., 2002).

\subsubsection{Surface display of short metal-binding histidine rich peptides}

Short, histidine rich metal-binding peptides have frequently been used to create more potent bioadsorbents (Sousa et al., 1996; Kotrba et al., 1999a; Xu and Lee, 1999; I). A novel cell surface display system was recently created by employing the E. coli outer membrane protein $\mathrm{C}(\mathrm{OmpC})$ as an anchoring motif. Polyhistidine peptides consisting of up to 162 amino acids could be successfully displayed when inserted in the seventh surface exposed loop of OmpC (Xu and Lee, 1999). Also, recombinant staphylococci with increased $\mathrm{Ni}$ - and $\mathrm{Cd}$-binding capacity have been generated through surface display of polyhistidyl peptides constituting the first successful report of using Grampositive cells for metal-binding applications (I). Gram-positive bacteria have been suggested to exhibit some advantages compared to Gram-negative bacteria (Malik et al., 1998) namely (i) translocation through only one membrane is required, and (ii) they are more rigid and therefore less sensitive to shear forces (Kelemen and Sharpe, 1979; Pagan et al., 1999) due to the thick peptidoglycan cell wall surrounding the cells, making them potentially more suitable for field applications such as 
bioadsorption. For metal adsorption applications, Gram-positive bacteria have the additional advantage of having an inherent metal-binding capacity due to the thick peptidoglycan layer (Mullen et al., 1989).

\subsubsection{Surface display of tailor-made metal-binding proteins}

The MTs, PCs, and peptides described in the preceding sections bind metal-ions in a rather non-specific fashion. It would however be desirable to create tailor-made bacteria exhibiting high affinity and specificity towards the target in question. Obvious approaches would be to engineer MTs or to use a combinatorial engineering approach to isolate peptides/proteins with a specific affinity and to express it on the surface of bacteria. Using this latter approach Mejáre and co-workers used a phage displayed peptide library to isolate novel peptides with affinity for cadmium (Mejáre et al., 1998). One of the selected peptides was expressed on the surface of E. coli cells through genetic fusion to a surface exposed portion of the outer membrane protein $\mathrm{A}$ (OmpA) generating bacteria with increased Cd-binding capacity. In a similar manner, as will be described in the present investigation, $\mathrm{Ni}^{2+}$-binding $S$. carnosus cells were generated through surface display of combinatorially engineered variants of a fungal cellulose-binding domain (CBD) from Trichoderma reesei cellulase Cel7A (III). Also the use of fimbrial designer adhesins to create novel bioadsorbents have been reported (Schembri et al., 1999; Kjaergaard et al., 2001).

The above mentioned examples suggest that surface display of engineered metalbinding peptides/protein on bacteria might become a useful strategy for the effective bioremediation of contaminated soil and industrial wastewaters. However, this type of research is still a relatively new area and several problems need to be adressed before it can become applicable for field applications. Mainly, the amount of metals sequestered by the bacteria is too small and very large amount of cells would be needed for it to become useful in routine applications. Perhaps the most promising applications would be for removal of trace amounts of contaminants using designerproteins with very high affinity and specificity towards the target metal in question. 


\section{Staphylococcal surface display and its applications}

Initial efforts to display foreign proteins on bacterial surfaces were focused on Gramnegative bacteria (Charbit et al., 1986; Freudl et al., 1986). More recently also Grampositive species have been considered for cell display applications (Hansson et al., 1992; Samuelson et al., 1995). Systems aimed at surface display on Gram-positive bacteria have been suggested to exhibit beneficial traits compared to the more frequently used Gram-negative bacteria, including; (i) translocation through only a single membrane, (ii) a more robust nature of the cells (Pagan et al., 1999) and (iii) Cterminal anchoring of Gram-positive surface proteins make them potentially more appropriate for the insertion of large passenger proteins (Navarre and Schneewind, 1999). One obvious disadvantage of using Gram-positive bacteria for cell surface display is the lower frequency of transformation, as compared to Gram-negative bacteria.

Two Gram-positive species, which have been extensively investigated for surface display applications are the staphylococcal strains S. xylosus and S. carnosus. The traditional use of these food grade staphylococci has been as starter cultures in the ripening process of dry sausages (Liepe, 1982), and strains of S. carnosus have been isolated from fermented meat products throughout the world (Hammes et al., 1995; Fadda et al., 2002). Both strains are characterized as nonsporulating, nonmotile cocci, and grow predominantly in pairs or singly (Schleifer and Kloos, 1975; Schleifer and Fischer, 1982). They exhibit a low level of DNA homology with S. aureus and do not produce toxins, haemolysins, protein A, coagulase or clumping factors (Götz, 1990). $S$. carnosus have been investigated as host for recombinant protein expression of various recombinant products (Hansson et al., 2002). Systems for intracellular as well as secreted production have been described (Schnappinger et al., 1995; Hansson et al., 2002; Williams et al., 2002). In addition, S. carnosus has been classified as a GRASorganism (generally regarded as safe) (Götz, 1986) and should therefore be suitable for vaccine delivery.

The following sections will give a brief introduction to the development of surface display systems for S. xylosus and S. carnosus, and the use of these systems for vaccine delivery and potential diagnostic applications. Other applications will be covered in the present investigation section of this thesis. For a more comprehensive 


\section{Staphylococcal protein A}

Charged repetitive region - postulated to interact with the peptidoglycan cell wall

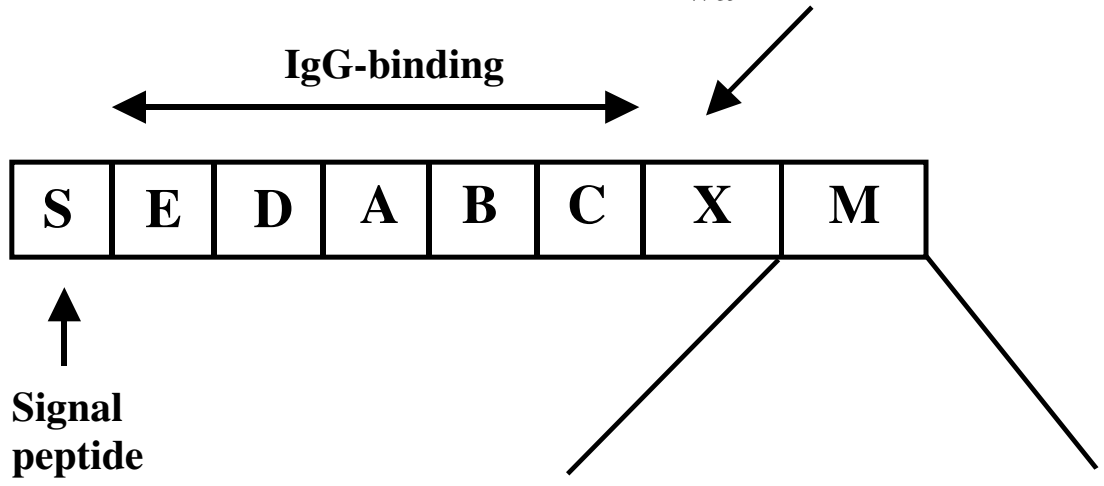

LPXTG

RRREL

个

Position for cleavage and covalent linkage to the cell wall

Short charged tail

Figure B: Schematic representation of the different regions of staphylococcal protein A.

Staphylococcal protein A (SpA) is a cell wall anchored receptor found on the gram-positive bacteria Staphylococcus aureus. The complete gene of SpA was sequenced by Uhlén and co-workers in 1984 and indicated a highly repetitive structure (Uhlén et al., 1984). Structural and functional studies later revealed that the gene could be divided into three distinct regions consisting of an $\mathrm{N}$ terminal signal sequence (Abrahmsén et al., 1985), five highly homologous IgG-binding domains (Moks et al., 1986) and a C-terminal sorting signal responsible for cell wall sorting and anchoring (Guss et al., 1984; Schneewind et al., 1995). The C-terminal region is composed of a charged repetitive region X, postulated to interact with the peptidoglycan cell wall (Guss et al., 1984) and M, which is a tripartite region consisting of an LPXTG-motif, a stretch of hydrophobic amino acids and a short charged tail (Schneewind et al., 1995). Sequencing of more than 100 surface proteins of gram-positive bacteria has showed that the LPXTG-motif is highly conserved and fuctions as the recognition site for proteolytic cleavage between the threonine $(\mathrm{T})$, and glycine $(\mathrm{G})$ residues followed by covalent linkage to the peptidoglycan cell wall (Navarre and Schneewind, 1994). The charged tail is required to prevent secretion into the medium and to position the LPXTG-signal for proteolytic cleavage. The enzyme responsible for proteolytic cleavage and subsequent cell wall anchoring has been identified and named sortase (Ton-That et al., 1999; Ton-That et al., 2000). The strong interaction between SpA and the IgG Fc-region has made it attractive for affinity purification of immunoglobulins (Langone, 1982). Of the four human subclasses of IgG, SpA binds to IgG1, IgG2 and IgG4 but only weakly to IgG3 (Kronvall and Williams, 1969). Also, domains of SpA have been used as fusion partners for facilitated production and affinity purification on IgG-sepharose (Nilsson et al., 1997). An engineered IgG-binding protein Z, based on the B-domain of SpA has been developed and used for facilitated production and affinity purification of recombinant proteins (Nilsson et al., 1987). The Z-domain has also been used as a scaffold for combinatorial protein engineering generating a novel class of affinity proteins called affibodies (Nord et al., 1995; Nord et al., 1997) 
summary the reader is advised to read the reviews by Hansson and co-workers, and Ståhl and co-workers (Ståhl and Uhlén, 1997; Hansson et al., 2001).

\subsection{Staphylococcal surface display vectors}

A plasmid vector approach was used in the development of the staphylococcal surface display systems. The use of high copy-number shuttle vectors, instead of chromosomal integration has the advantage of providing multiple copies of the gene per cell and that the genetic constructions can be made using E. coli. Two general expression vectors pSEmp18ABPXM (Hansson et al., 1992; Nguyen et al., 1995) and pSPPmABPXM (Samuelson et al., 1995) designed for surface display on S. xylosus and S. carnosus, respectively, have been developed (Figure 2). Both vector systems utilize the cell wall anchoring region, denoted XM, from staphylococcal protein A (Schneewind et al., 1995) to achieve proper anchoring and display of various chimeric proteins at the bacterial surface (Figure B). The mechanism for cell wall sorting and anchoring of SpA has been elucidated (Mazmanian et al., 1999) and the enzyme responsible for this process has been identified and named sortase (Mazmanian et al., 1999). The high homology in the C-termini among numerous Gram-positive surface proteins makes it highly plausible that there is a common mechanism for cell surface targeting among many Gram-positive bacteria (Schneewind et al., 1995; Strauss et al., 1998; Mazmanian et al., 1999).

The two constructed vector systems differ in that the $S$. xylosus vector, pSEmp18ABPXM (Figure 2A), contains the promoter and signal sequence (S) from SpA (Hansson et al., 1992; Nguyen et al., 1995), while the S. carnosus vector, pSPPmABPXM (Figure 2B), utilizes the promoter, signal sequence, and propeptide sequence (PP) from a Staphylococcus hyicus lipase gene (Samuelson et al., 1995), to achieve translocation through the cellular membrane. The inclusion of the albumin binding protein (ABP) from streptococcal protein $G$ fulfills three important criteria. First, it acts as a spacer molecule increasing the accessibility of displayed chimeric molecules at the bacterial surface (Ståhl et al., 1997). Secondly, the inclusion of an affinity handle has allowed efficient purification and characterization of surface displayed receptors extracted from the cell wall (Samuelson et al., 1995). Finally, it has been demonstrated to serve as a reporter region for efficient enzymatic or flow 
A
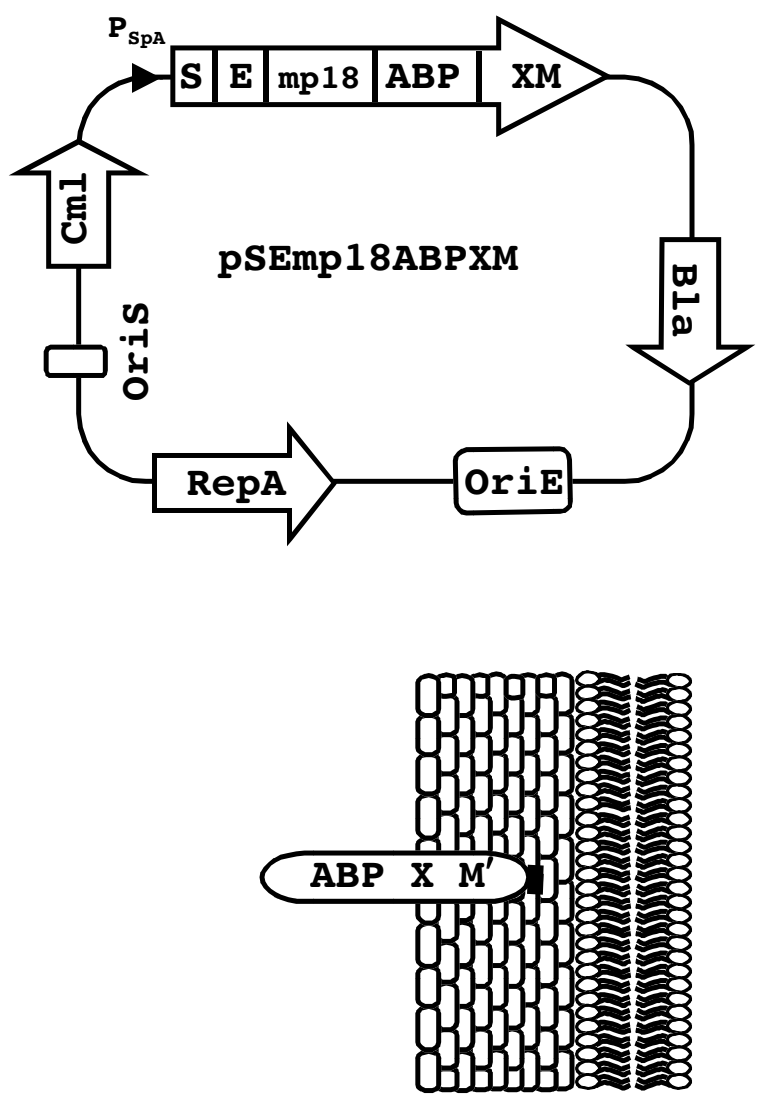

B
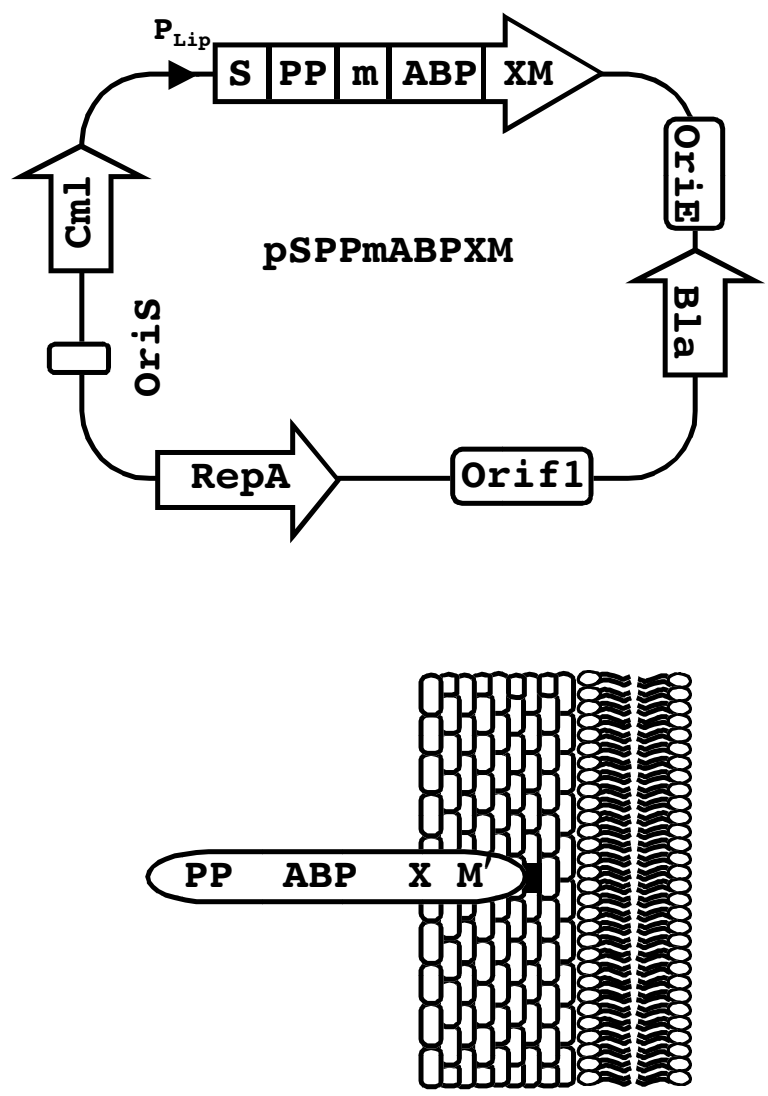

Figure 2: Expression vectors with encoded gene products. (A) The expression vector pSEmp18ABPXM suitable for surface display in S. xylosus with the processed gene fusion product illustrated as anchored to the cell surface. (B) The expression vector pSPPmABPXM suitable for surface display in S. carnosus with the processed gene fusion product illustrated as anchored to the cell surface. When a target gene is introduced into the multiple cloning sites of the vectors, the encoded target protein is expected to be exposed as illustrated anchored to the staphylococcal cell surface. Note, that the propeptide (PP) from the S. hyicus lipase is not processed in S. carnosus. M' represents the processed and covalently anchored form of the $M$ sequence of staphylococcal protein $A$, (SpA). Abbreviations: Bla, B-lactamase encoding gene; $\mathrm{Cml}$, chloramphenicol acetyltransferase-encoding gene; Orif1, origin of replication for phage f1; OriE, origin of replication from E. coli; OriS, origin of replication from $S$. aureus; $\mathrm{P}_{\mathrm{SpA}}$ promoter region from the $\mathrm{SpA}$ gene; $\mathrm{P}_{\text {Lip }}$, S. hyicus promoter region designed for $S$. hyicus lipase production in S. carnosus. Note that the propeptide (PP) from $S$. hyicus is not processed in S. carnosus.

cytometric monitoring of displayed chimeric proteins at the bacterial surface (Andréoni et al., 1997). It has been shown that the lipase propeptide, which is not processed in S. carnosus, but in its homologous host S. hyicus is essential for efficient secretion of chimeric gene fusion products when using the lipase promoter and signal peptide (Demleitner and Götz, 1994; Samuelson et al., 1999). The two E. colistaphylococci shuttle vectors, pSEmp18ABPXM (Figure 2A) and pSPPmABPXM (Figure 2B), have the following features in common: (i) the origin of replication for 
$E$. coli and the $\beta$-lactamase gene giving ampicillin resistance to transformed $E$. coli cells, (ii) an origin of replication functional in $S$. aureus and the chloramphenicol acetyltransferase gene for selection in staphylococci, (iii) a gene fragment encoding the serum albumin-binding protein (ABP) derived from streptococcal protein $\mathrm{G}$ (Samuelson et al., 1995), (iv) gene fragments encoding the cell wall anchoring region from SpA (XM) (Schneewind et al., 1995). In addition, the S. carnosus vector pSPPmABPXM carries the origin of replication for phage $\mathrm{f} 1$. It has been demonstrated, using a quantitative FACS strategy that the S. xylosus system expose in the order of $10^{3}$ heterologous surface proteins per cell while the $S$. carnosus system has been shown capable of exposing approximately $10^{4}$ surface proteins per bacterium (Andréoni et al., 1997). These figures are in accordance with the data given by Strauss and Götz who used a similar, S. carnosus-based, display system for the expression of enzymes on staphylococci. By enzymatic methods they estimated that approximately $10^{4}$ enzyme molecules were exposed per staphylococcal cell (Strauss and Götz, 1996). The numbers for the $S$. carnosus display systems are thus comparable with E. colibased systems.

\subsection{Staphylococcal vaccine delivery}

Since the investigated staphylococcal strains have been used in food applications they have been considered also for vaccine delivery purposes. Furthermore, the staphylococci have been shown to be non-pathogenic and indeed safe to administer by mucosal or subcutaneous routes up to very high doses (Ståhl et al., 1997). In an initial immunization study, mice were immunized orally with S. xylosus cells carrying a chimeric surface exposed protein, BBG3 consisting of a part of streptococcal protein $G$ fused to a trimerized epitope from the $G$ protein of respiratory syncytial virus (RSV) (Nguyen et al., 1993). Serum IgG-antibodies reactive to the novel surface protein BBG3 were evoked and could still be detected after 143 days. Subsequent studies showed that surface accessibility of the immunogen was indeed necessary for induction of antibody responses to the heterologous surface antigens when using live recombinant S. xylosus as vaccine delivery system (Nguyen et al., 1995). The presence of serum antibodies reactive to the foreign antigen was demonstrated in a majority of the mice immunized with bacteria carrying the surface-displayed antigen, while none of the sera from mice immunized with the bacteria encoding a 
nonsecretable form of the same antigen showed antibody reactivity. The antibody responses were variable but the results nevertheless clearly demonstrated that surfacedisplay was necessary in order to elicit antibody responses to heterologously expressed peptides using this staphylococcal delivery system (Nguyen et al., 1995).

The results from a comparative immunization study between the $S$. carnosus (Samuelson et al., 1995) and the S. xylosus (Hansson et al., 1992) surface display systems, showed a stronger antibody response to the model immunogen ABP when employing the S. carnosus system for immunizations (Ståhl et al., 1997). A suggested explanation was the higher surface density of foreign surface protein on the $S$. carnosus cells (Robert et al., 1996; Andréoni et al., 1997) thus corresponding to a higher immunization dose of the ABP-antigen although the same amount of live recombinant bacteria was administered.

Although systemic antibody responses to surface-exposed antigens were reported after oral delivery with the S. carnosus system, the antibody titers were generally quite moderate using the initial versions of the staphylococcal vaccine delivery vehicles (Liljeqvist and Ståhl, 1999). Attempts were therefore made to modify the staphylococcal delivery vehicles in order to improve antibody responses elicited to the surface exposed epitopes upon immunization via mucosal routes (Liljeqvist et al., 1997a; Liljeqvist et al., 1997b; Cano et al., 1999; Liljeqvist et al., 1999). The rationale for these attempts were to co-display proteins with adhesive properties as fusions to the model immunogen and thereby targeting the staphylococcal vaccine vehicles to the mucosal epithelium. The first attempts involved surface expression of a bacterial adhesion factor, a fibronectin binding domain from Streptocococcus dysgalactiae, on the surface of $S$. carnosus, resulting in a $1.5 \log _{10}$ increase in the serum IgG responses to the co-displayed antigen, ABP, upon intranasal immunization of mice (Liljeqvist et al., 1999). In another approach, co-exposure of a peptide (CTBp) comprising amino acids 50 to 75 of the cholera toxin B (CTB) subunit on the S. carnosus surface, was investigated. The CTBp subfragment of CTB has been demonstrated to have an immunopotentiating effect (Delmas and Partidos, 1996) thereby making it interesting as a carrier adhesion molecule for mucosal vaccine development. This effect is considered to be related to its ability to bind to the monosialoganglioside GM1, present on mucosal epithelial cells (Liljeqvist et al., 1997a; Cano et al., 1999). The 
surface display of this CTBp subfragment as a fusion to the model immunogen ABP, resulted in significantly increased (close to $2 \log _{10}$ ) serum $\mathrm{IgG}$ responses when using an intranasal route of administration with such recombinant $S$. carnosus cells (Cano et al., 1999). The S. carnosus system, improved by co-display of CTBp, was subsequently used for delivery of three different peptides derived from the $G$ glycoprotein of human respiratory syncytial virus (RSV) (Cano et al., 2000). Intranasal immunization of mice with the live recombinant staphylococci elicited significant anti-peptide as well as anti-virus serum IgG responses, and upon viral challenge with $10^{5}$ tissue culture infectious doses50 (TCID 50 ), lung protection was demonstrated for approximately half of the mice in two of the immunization groups. This represented the first study in which protective immunity to a viral pathogen has been evoked using food-grade bacteria as vaccine-delivery vehicles (Cano et al., 2000).

\subsection{Microbial biocatalysis through enzyme display}

Enzymes have been expressed with retained activity on the surface of Gram-negative and Gram-positive bacteria (Ståhl et al., 2000) and the potential use of such recombinant bacteria as novel microbial biocatalysts have been discussed in the preceding sections. In a pioneer study for Gram-positive enzyme display, a lipase from Staphylococcus hyicus and also E. coli ß-lactamase were expressed on the outer cell surface of S. carnosus with retained activity (Strauss and Götz, 1996). The surface display system was similar to the one described for the vaccine approaches above, but the cell surface anchoring regions from $S$. aureus fibronectin protein B (FnBPB) was used instead of the SpA-based regions to achieve proper cell-wall anchoring. Approximately 10,000 enzyme molecules were estimated to be present on each cell, and it was suggested that the rigid structure of Gram-positive bacteria would make them particularly appropriate as microbial catalysts (Strauss and Götz, 1996).

\subsection{Binding proteins for diagnostic applications}

Functional single-chain antibody fragments ( $\mathrm{scFvs}$ ) have been expressed as part of surface proteins on E. coli and staphylococcal cells (Gunneriusson et al., 1996; Ståhl et al., 2000). This type of bacteria could be seen as "whole-cell monoclonal antibodies" that potentially could be exploited as a novel type of diagnostic devise in 
different immunological tests. In a pioneering study, the functional expression of a murine anti-human-IgE scFv antibody fragment as surface exposed on S. xylosus and S. carnosus, cells was demonstrated (Gunneriusson et al., 1996). Whole cell assays indicated that the recombinant bacteria, and in particular S. carnosus were indeed able to recognize the target immunogen, human $\operatorname{IgE}$.

In a subsequent study, it was investigated whether tailor-made binding molecules, termed affibodies (Nord et al., 1995; Nord et al., 1997), created by combinatorial protein engineering of an $\mathrm{SpA}$ domain, $\mathrm{Z}$ (originally binding to $\mathrm{IgG} \mathrm{Fc}$ ), were suitable for surface display on $S$. carnosus cells. Using genetic engineering, combinatorial libraries of the $\mathrm{Z}$ domain were recently created in which 13 surface located amino acid residues, involved in the IgG Fc binding, were randomly and simultaneously substituted (Nord et al., 1997). Through the genetic fusion of these Z-libraries to the coat protein III of filamentous phage M13, phage libraries adapted for the selection of novel affinity variants were created. This strategy has been successfully used to select affibodies to such diverse targets as Taq DNA polymerase, human recombinant factor VIII, human insulin, a human apolipoprotein variant and the G protein of human RSV (Nord et al., 1997; Hansson et al., 1999; Nord et al., 2001). The same strategy has been employed to select affibody ligands against human $\operatorname{IgA}$ and $\operatorname{IgE}$, respectively (Gunneriusson et al., 1999a; Gunneriusson et al., 1999b). The objective of the second study was to investigate whether the $\operatorname{IgA}$ and $\operatorname{IgE}$ reactive affibodies could be functionally expressed in chimeric surface proteins on S. carnosus. The chimeric proteins were succesfully targeted to the staphylococcal cell wall, and most importantly, the generated staphylococci were indeed capable of binding $\operatorname{IgA}$ and $\operatorname{IgE}$, respectively (Gunneriusson et al., 1999b). The staphylococcal origin of the SpA based affibodies might explain the higher expression levels and improved proteolytic stability observed in the second study (Gunneriusson et al., 1999b). One practical application for these types of recombinant bacteria would be to use them as a straightforward and cost-effective way of producing "monoclonal antibodies" for diagnostic applications. They might also become useful in "immunoprecipitation" experiments or as inexpensive bioadsorbents for recovery of $\operatorname{IgE}$ or $\operatorname{IgA}$, see also section 2.2 . 


\section{Present Investigation}

\section{Generation of metal-binding staphylococci (I, III)}

The increasing accumulation of potentially harmful substances in our environment due to agricultural and industrial applications is a growing concern for public health. This is why environmental biotechnology currently attracts a lot of attention since genetically engineered plants and bacteria might be used for generation of novel bioadsorbents for sequestration of toxic metals, or for the enzymatic degradation of other harmful substances (Mejáre and Bülow, 2001). Bacterial sequestration of heavy metal contaminants has previously been investigated using nonengineered bacteria (Mullen et al., 1989), but recombinant DNA technology offers the possiblity to improve the metal-binding capacity of the bacteria by genetic modifications. Initial attempts to increase the metal-binding capacity of bacteria by recombinant means focused on the intracellular expression of metallothioneins, phytochelatins and other cysteine-rich peptides produced by higher organisms in response to heavy-metal challenge (Pazirandeh et al., 1995; Pazirandeh, 1996). Today, the most common strategy for generation of novel bioadsorbents is surface display of the metal-binding peptides/proteins providing the possibility to recycle the biomass by desorption of the accumulated heavy-metals (Mejáre and Bülow, 2001).

Efforts to create recombinant bacteria with improved metal-binding capacity, have so far been concentrated on E. coli. However, the use of lab-born E. coli strains might not be the optimal solution for in-situ soil remediation and other strains should therefore be investigated (Valls et al., 2000a; Valls et al., 2000b; Bae et al., 2002). Gram-positive surface display systems have, as been discussed earlier, been suggested to exhibit some advantages compared to gram-negative bacteria (Ståhl et al., 1997; Malik et al., 1998) and for metal adsorption applications, gram-positive bacteria have the additional advantage of having inherent metal-binding capacity due to the thick peptidoglycan layer (Mullen et al., 1989).

\subsection{Surface display of polyhistidyl peptides (I)}

In an initial attempt to recruit also gram-positive bacteria for bioadsorption purposes we used the previously described surface display systems for S. xylosus and $S$. carnosus (Figure 2) to express metal-binding peptides on the bacterial cell surface. 


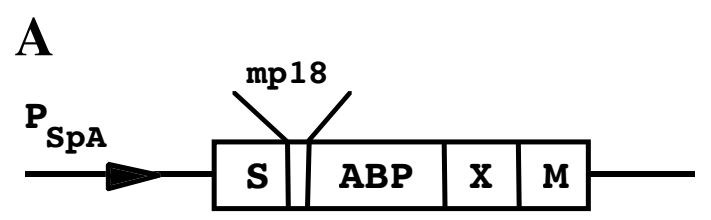

[ pSEmp18ABPXM]

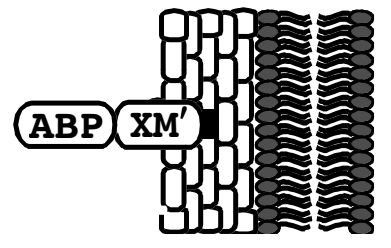

\begin{tabular}{llll} 
Strain: & Plasmid: & Protein: & Size (kDa): \\
\hline Sx: ABP & pSEmp18ABPXM & ABPXM' & 43 \\
Sx:H1ABP & pSEH1ABPXM & H1ABPXM' & 44 \\
Sx:H2ABP & pSEH2ABPXM & H2ABPXM' & 44 \\
\hline
\end{tabular}
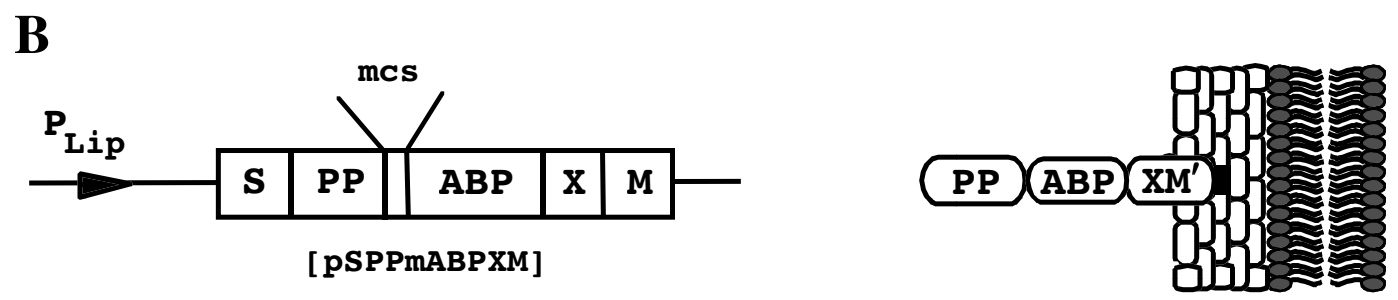

\begin{tabular}{llll} 
Strain: & Plasmid: & Protein: & Size (kDa): \\
\hline SC:ABP & pSPPMABPXM & PPABPXM' & 65 \\
SC:H1ABP & pSPPH1ABPXM & PPH1ABPXM' & 66 \\
SC:H2ABP & pSPPH2ABPXM & PPH2ABPXM' & 66 \\
\hline
\end{tabular}

Figure 3. Expression cassettes of the parental expression vectors designed for surface display on (A) S. xylosus and (B) S. carnosus shown with their encoded gene products anchored to the cell wall. The abbreviated names of the recombinant staphylococcal strains are shown together with the names of the constructed expression vectors aimed for surface display of polyhistidyl peptides, produced cellwall anchored proteins and estimated molecular masses (H1: HHHEHHH; H2: HHHHHH).

Two different polyhistidyl peptides, $\mathrm{His}_{3}-\mathrm{Glu}-\mathrm{His}_{3}$ denoted $\mathrm{H} 1$, and $\mathrm{His}_{6}$ denoted $\mathrm{H} 2$, were introduced into the two different display vectors generating four recombinant staphylococcal strains schematically depicted in Figure 3, together with the parental vector constructs. Proper expression and surface localization of the different chimeric proteins was demonstrated since they could be recovered as full-length proteins by ABP-mediated affinity based chromatography from cell wall extracts of both $S$. xylosus and S. carnosus. Surface accessibility of the heterologous proteins was demonstrated by a whole-cell enzymatic assay using the ABP-domain as a reporter molecule. Recombinant and wild-type staphylococci were grown to early logarithmic phase, harvested, and then incubated with biotinylated-HSA, followed by an incubation with a streptavidin-alkaline phosphatase conjugate. The presence of surface displayed ABP-containing surface proteins was detected using a chromogenic 
substrate. All recombinant staphylococci showed a significant positive response while wild-type S. xylosus and S. carnosus, not expressing any albumin binding proteins, were negative in this assay. The chimeric surface proteins were thereby shown to be targeted and anchored, in accessible forms, to the outer surface of the recombinant staphylococci.

A

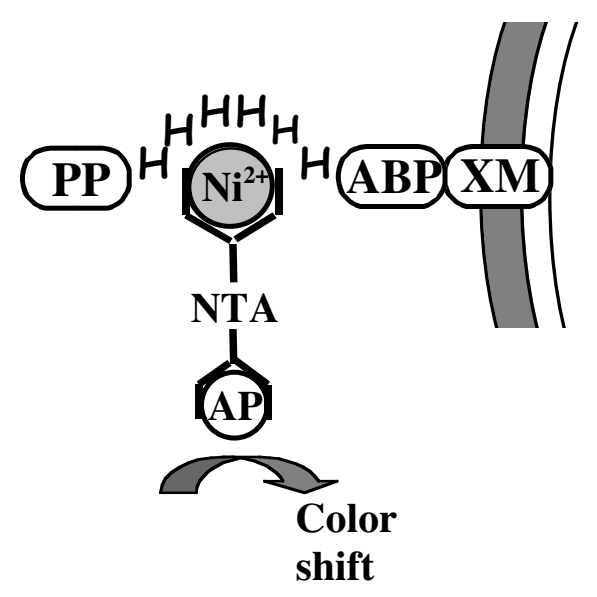

B

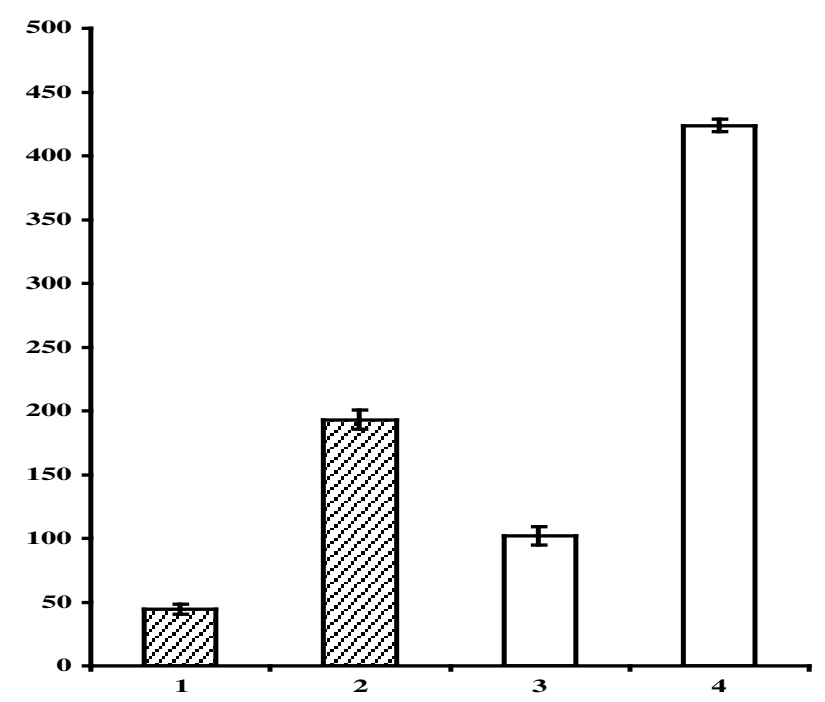

Figure 4. (A) Schematic representation of the whole-cell $\mathrm{Ni}^{2+}$-binding assay. Wild-type and recombinant $S$. xylosus or $S$. carnosus cells, respectively, were incubated with nickel-chelated alkaline phosphatase conjugate. Upon addition of substrate, the color response was monitored in five separate samples from each construct. (B) Histogram representation of the results from the whole-cell $\mathrm{Ni}^{2+}$ binding assay. Bars indicate the $\mathrm{A}_{405 \mathrm{~nm}}$ response for S. xylosus cells (shaded bars); wild type (bar 1), and Sx:H2ABP (bar 2), as well as for S. carnosus cells (open bars); wild type (bar 3), and Sc:H2ABP (bar 4). Error bars represent standard deviation (SD).

The $\mathrm{Ni}^{2+}$-binding capacity of the recombinant strains was evaluated in a whole cell format using a $\mathrm{Ni}^{2+}$-chelating alkaline phosphatase conjugate (Figure 4a). It was demonstrated that staphylococcal cells expressing the continous hexahistidyl peptide (H2) showed higher $\mathrm{Ni}^{2+}$-binding capacity than wild-type cells not expressing any recombinant metal-binding peptide (Figure 4b). Furthermore, the continous $\mathrm{His}_{6}$ peptide $(\mathrm{H} 2)$ seemed in both systems to give a significantly higher metal-binding capacity than the discontinous $\mathrm{His}_{3}-\mathrm{Glu}-\mathrm{His}_{3}$ peptide (H1). The overall higher metalbinding capacity, observed for the $S$. carnosus constructs is most likely due to the higher level of expression compared to the S. xylosus system. It has been demonstrated that the $S$. carnosus system displays approximately 10000 recombinant 
A

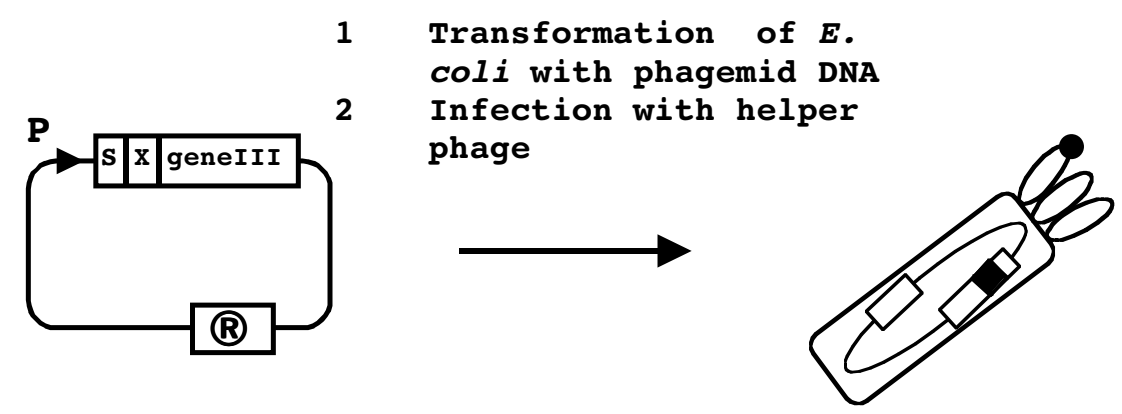

B

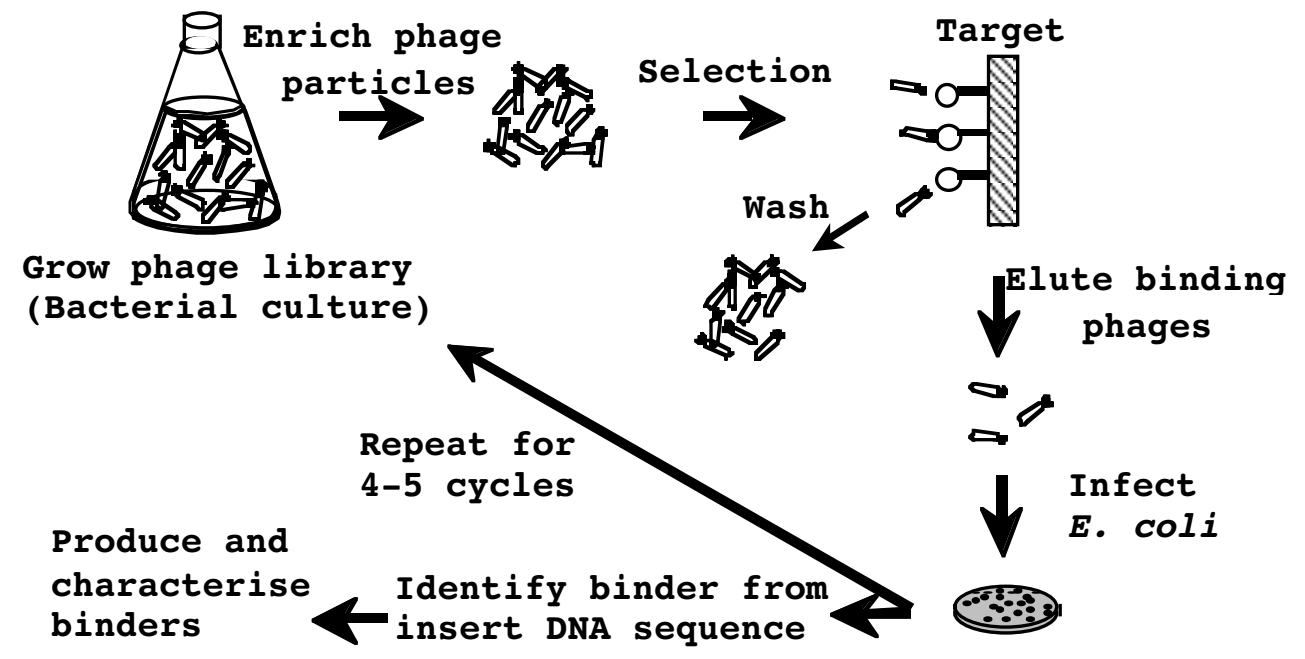

C

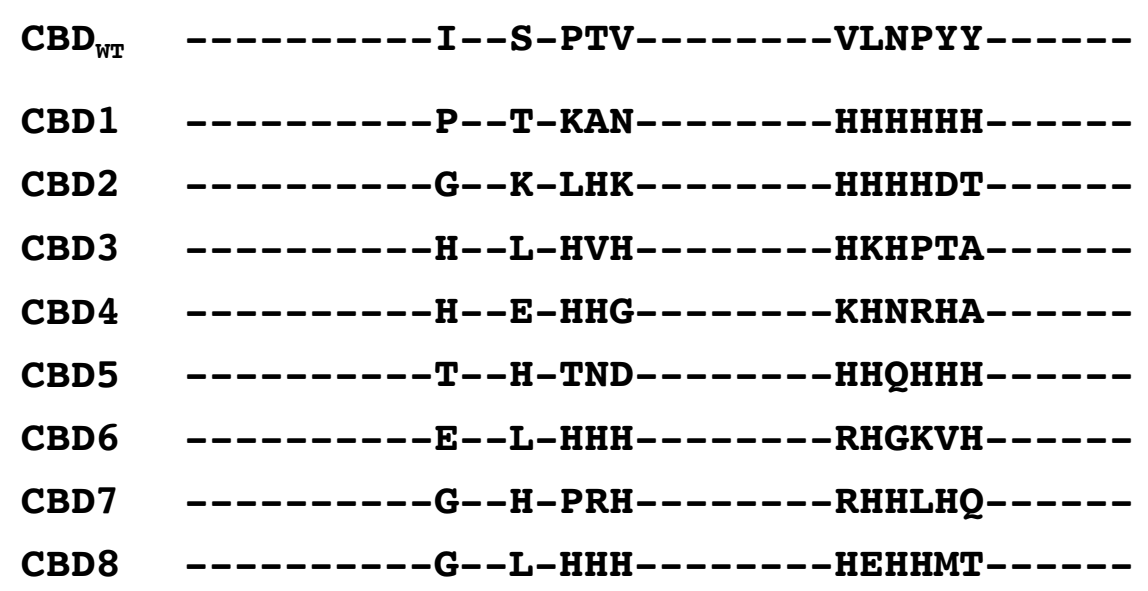

D
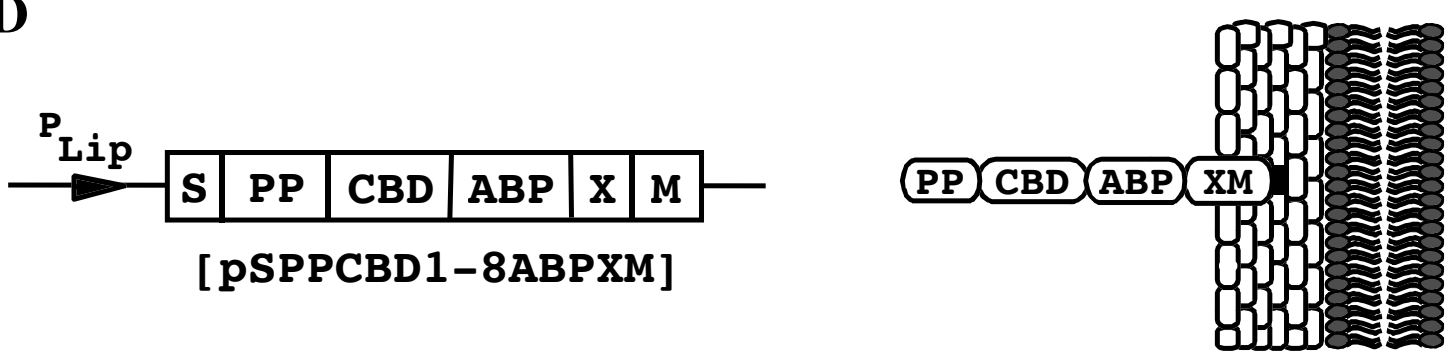
surface proteins per bacterial cell while the S. xylosus system generates bacteria with roughly 1000 surface exposed proteins (Andréoni et al., 1997).

When evaluating the possibility of using the recombinant staphylococci also for cadmium binding only slightly improved Cd-binding could be demonstrated for the $\mathrm{H} 2$ expressing cells. This is most likely explained by the fact that hexahistidyl peptides are not optimal for Cd-binding, suggesting that alternative peptides/proteins should be investigated in order to generate staphylococci with increased Cd-binding capacity (Pazirandeh et al., 1998; Kotrba et al., 1999a). Recently, approaches based on combinatorial peptide libraries have allowed selection of peptides with enhanced specificity for a certain metal, using either bacterial (Brown, 1997; Schembri et al., 1999) or phage display strategies (Patwardhan et al., 1997; Mejáre et al., 1998). Surface display of such peptides on bacterial surfaces could potentially be used to create tailor-made recombinant strains for use as selective bioadsorbents or biosensors. Such approaches would be of obvious interest also for our staphylococcal display systems.

\subsection{Tailor-made metal-binding staphylococci (III)}

In this study we investigated the possibility to generate tailor-made metal-binding staphylococci by combining phage display based combinatorial protein engineering with subsequent surface display of selected binders on S. carnosus. A previously constructed, phage-displayed combinatorial protein library (Figure 5A) based on a fungal cellulose-binding domain (CBD), derived from the cellobiohydrolase Cel7A of Trichoderma reseii (Lehtiö et al., 2000) was used in a biopanning format against $\mathrm{Ni}^{2+}$ coated magnetic agarose beads for selection of novel metal-binding CBDs (Figure 5B). Eight such engineered CBD variants, now devoid of cellulose binding, were randomly selected and sequenced after five consecutive rounds of biopanning.

Figure 5. (A) Schematic representation of the phagemid system. E. coli cells are transformed with the phagemid containing the foreign gene fused to the phage coat protein III. Growing cells are coinfected with helper phage to produce new phage particles, which are now decorated with the fusion protein. (B) Schematic representation of a standard biopanning procedure for selection of novel binders. The variants with affinity towards the desired target are selectively enriched and after several rounds, the selected variants are identified by DNA sequencing, produced and further characterized. (C) Amino acid sequences of the wild-type and engineered CBD variants at the randomized positions. (D) Expression cassette of the plasmid vector designed for surface display on S. carnosus, shown with encoded gene products illustrated as anchored to the staphylococcal cell wall. The name of the constructed vectors are given below the expression cassette. 
Sequence analysis of all selected CBD-variants revealed a marked preference for histidine residues at the randomized positions, corresponding to $41 \%$ of the total amino acid content at substituted codons (Figure 5C), with Sc:CBD1 containing six consecutive histidine residues and Sc:CBD6 also being rich in histidines (Figure 5C). There did not seem to be a marked preference for certain positions for the histidine residues. In fact, histidine residues were found in all of the randomized positions, taking into account all the eight investigated CBD variants. This would indicate that the principle of phage-mediated biopanning against the $\mathrm{Ni}^{2+}$-NTA agarose beads was indeed functioning.

The engineered CBDs were inserted into the S. carnosus display vector and analysed for correct cell-wall targeting and accessibility of displayed molecules at the cell surface taking advantage of the ABP-domain as an affinity handle and reporter molecule, repectively (Figure 5D). The heterologous surface proteins could be recovered as full-length proteins with little or no proteolytic degradation. The metalbinding capacity of recombinant and wild-type $S$. carnosus cells was investigated by the previously described whole-cell $\mathrm{Ni}^{2+}$-binding assay. The results clearly indicated that all recombinant strains had gained metal-binding capacity when compared to the wild-type staphylococcal strain. Furthermore, two of the strains, Sc:CBD1 and $\mathrm{Sc}$ :CBD6, showed a significant increase in $\mathrm{Ni}^{2+}$-binding compared to the cells expressing only the $\mathrm{ABP}$, while the remaining six recombinant strains showed intermediate or no increase in metal-binding properties when compared to the ABPvariant.

If solid supports with other chelated metal ions were available, it would be highly interesting to investigate whether CBD-variants showing specific binding to these ions could be selected. If so, this could be used as a general strategy for generating recombinant staphylococci with tailor-made metal-binding specificities, for use as specific whole-cell bioadsorbents. Furthermore, if fluorescent reagents with chelated metal ions were available, the biopanning might be performed by flow cytometric cell sorting of a surface displayed CBD library. This would have the obvious advantage of eliminating the initial phage display selection procedure. 


\section{Directed immobilization of recombinant staphylococci (II)}

Cell immobilization has widespread use in modern biotechnology, including the production of ethanol (Nigam, 2000) and the degradation of phenol (LeBaron et al., 1999). Other areas where bacterial immobilization could become useful are for the generation of whole-cell biofilters for sequestration of heavy metal contaminants or for the effective degradation of potentially harmful substances accumulating in our environment.

Bacterial cells can be either bound to a support or entrapped within a matrix such as polyacrylamide or polyurethane. The latter generally results in mass transfer limitations between the cell and the surroundings (Pilkington et al., 1998). Initially, whole-cell immobilization was achieved through simple physical adsorption processes resulting in the gradual loss of cells from the solid support material (Wang et al., 2002). These limitations can be solved either by covalent coupling of the cells to the support or by receptor-mediated specific adhesion. The covalent coupling strategy prohibits effective regeneration of the matrix and often results in loss of activity and cell viability. Potential advantages of directed immobilization through an affinity tag are binding specificity and the ability to regenerate the support matrix when the activity drops below acceptable levels.

A

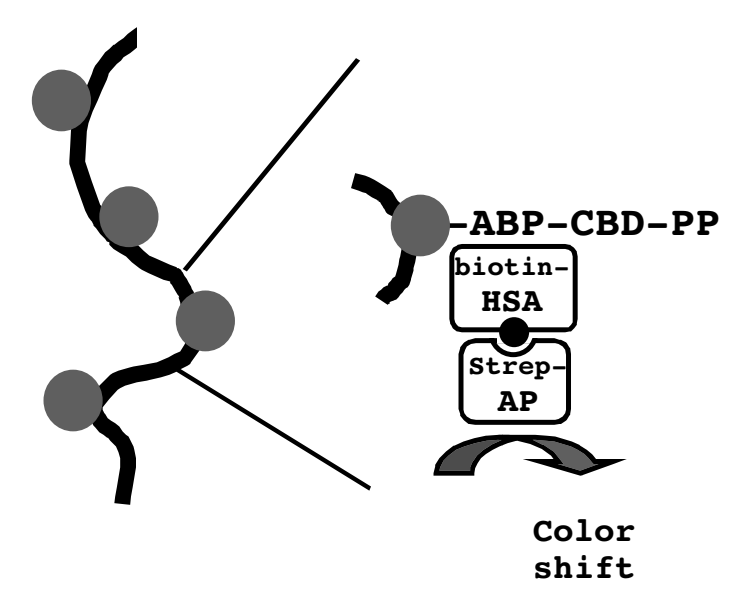

B

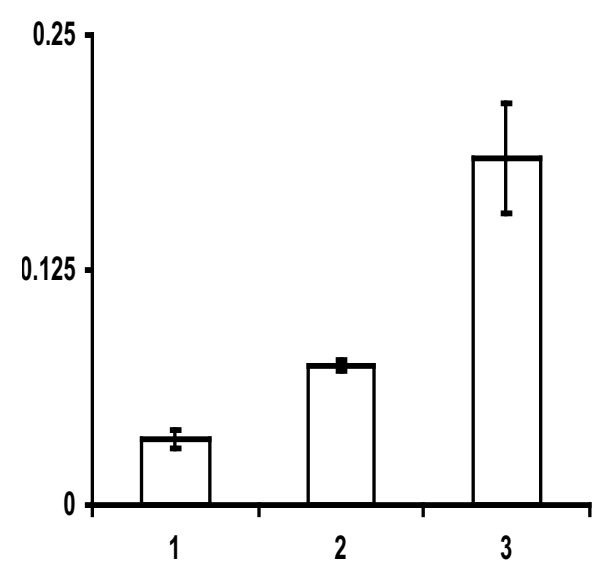

Figure 6. Cellulose-binding was analysed for the different staphylococcal cells by measuring the amount of recombinant staphylococci bound to cotton fibers. (A) Wild-type and recombinant $S$. carnosus cells were incubated with cotton fibers. After subsequent washing steps biotinylated HSA, and streptavidin alkaline phosphatase conjugate was added to cotton fibers and the colour shift $\left(\mathrm{A}_{405 \mathrm{~nm}}\right)$ was monitored upon addition of chromogenic substrate. (B) Histogram representation of results from fiber-binding assay. Wild-type (bar 1) and recombinant $S$. carnosus cells, Sc:ABP (bar 2) and Sc:CBD (bar 3). Note, that since this particular assay is not capable of detecting wild-type $S$. carnosus cells, these were included as a control for unspecific adherence of biotinylated HSA to cotton fibers. 
Cellulose-binding domains (CBDs) isolated from a variety of organisms have been widely used as affinity tags for protein purification and immobilization of heterologous proteins (Linder et al., 1998; Tomme et al., 1998) on solid supports. Cellulose is naturally abundant, chemically inert, non-toxic and offers an inexpensive immobilization matrix for many different purposes. Specific adhesion of bacterial cells to cellulose materials have previously been demonstrated by surface anchoring of a CBD from Cellulomonas fimi on E. coli cells providing a simple and economical immobilization strategy (Francisco et al., 1993b; Wang et al., 2001).

In this study we investigated the CBD of the cellobiohydrolase Cel6A (Linder and Teeri, 1996) from the filamentous fungii Trichoderma reesei for directed immobilization of recombinant $S$. carnosus cells on cotton fibers. Fungal CBDs bind to cellulose in a rapid, spontaneous and efficient fashion over a wide range of conditions and over a broad pH range (Reinikainen et al., 1995; Linder et al., 1999). Owing to its small size and slow dissociation rate, Cel6A CBD in particular constitutes a suitable tag to achieve cellulose immobilization (Linder and Teeri, 1996). A gene fragment encoding the 38-amino acid CBD was introduced into the general S. carnosus display vector pSPPmABPXM (Samuelson et al., 1995). Linker regions, similar to those naturally flanking the fungal CBDs, were introduced to increase the accessibility at the staphylococcal cell surface. Chimeric proteins containing the CBD were found to be correctly targeted to the cell wall since fulllength proteins could be extracted, affinity purified and detected in a western blot procedure. Surface accessibility of the CBD was verified in a whole-cell format using a monoclonal CBD-specific antibody (Aho et al., 1991) and a secondary alkalinephosphatase conjugated antibody generating a measurable color-shift upon substrate addition.

In addition, the ability of the staphylococcal cells to adhere to cellulose was investigated by incubating wild-type and recombinant, CBD-expressing S. carnosus cells with cotton fibers (Figure 6A). After incubation, the cotton fibers were extensively washed and staphylococcal binding was demonstrated using the previously described whole-cell colorimetric assay. The results demonstrated that significantly more Sc:CBD cells had bound to the cotton fibers (Figure 6B), compared to the Sc:ABP cells, used as control (Figure 6B). Since this particular assay is not 
A

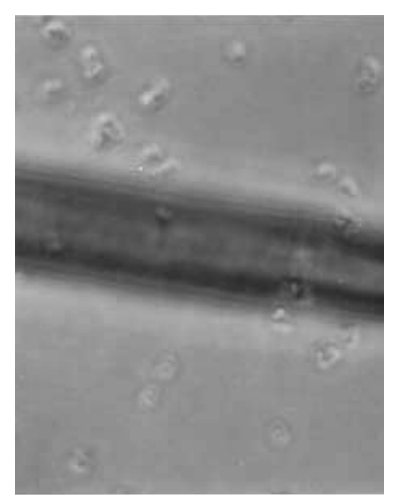

B

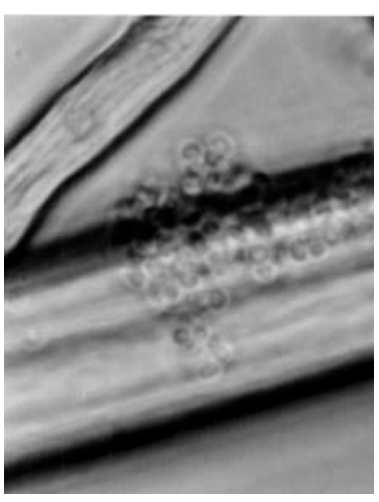

Figure 7. Microscopic analysis of cotton fibers after incubation with wild-type staphylococci (A) or recombinant $S$. carnosus with surface-exposed CBD (B) (magnification 1:100), reveals partial coating of the cotton fibers when incubated with the recombinant, CBD expressing strain.

capable of detecting wild-type $S$. carnosus cells, these were included as a control for unspecific adherence of biotinylated HSA to the cotton fibers, and as expected, the background binding was very low (Figure 6B). Furthermore, the specific binding of CBD displaying cells to cotton fibers was visualised by microscopic analysis (Figure 7). The results clearly show that the staphylococcal cells are intimately associated, almost as a monolayer, along the cotton fibers. Similar experiments using wild-type staphylococci or the Sc:ABP construct did not show any binding to the fibrous support.

The directed and reversible immobilization of recombinant microorganisms on solid supports might have several potential applications. Cellulose binding domains could be expressed together with the previously described metal-binding peptides or proteins on bacterial surfaces, enabling immobilization of the bacteria in order to create tools for effective bioremediation of heavy metal contaminated areas. Alternatively, bacteria expressing both active enzymes and CBDs could be immobilized on solid supports to be used as whole cell biocatalysts (Wang et al., 2002). Furthermore, potential diagnostic devices in a "dipstick" format could be created through immobilization of staphylococci with surface displayed antibody or affibody domains. Simultaneous display can be achieved either by co-expression as fusion proteins or by using two different surface anchoring motifs for the proteins to be expressed (Liljeqvist et al., 1999; Wang et al., 2002). 


\section{Second generation display vectors for S. carnosus (IV)}

The use of cell-based selection systems as attractive alternatives to filamentous phages for display of combinatorial protein libraries has in recent years turned into a focus area (Daugherty et al., 2000; Georgiou, 2001; Wittrup, 2001). This is because the display of large libraries on cell surfaces offers some advantages compared to traditional phage display approaches. In addition to a tight genotype-phenotype linkage the possibility of a rapid and extensive screening by flow cytometric cell sorting give cell based selection systems a competitive advantage since phages are too small to be analysed by flow cytometry (Georgiou, 2001). When using bacterial display for library applications the genetic stability of the expression system becomes a critical factor (Daugherty et al., 1999). This would be an issue if using the original S. carnosus display vector, pSPPmABPXM (Samuelson et al., 1995), which has showed problems related to structural instability, possibly due to the presence of a phage $\mathrm{f} 1$ origin of replication in the vector sequence (Ballester et al., 1989). However, this has not been considered a problem in previous applications (Ståhl et al., 2000; Hansson et al., 2001) where it has been enough to identify a single functional and well expressing clone.

A

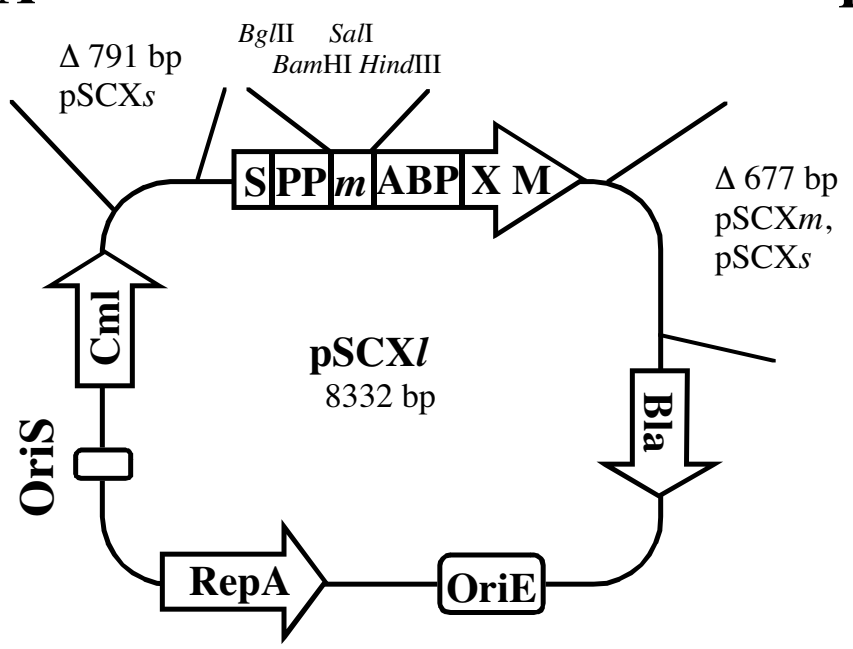

B

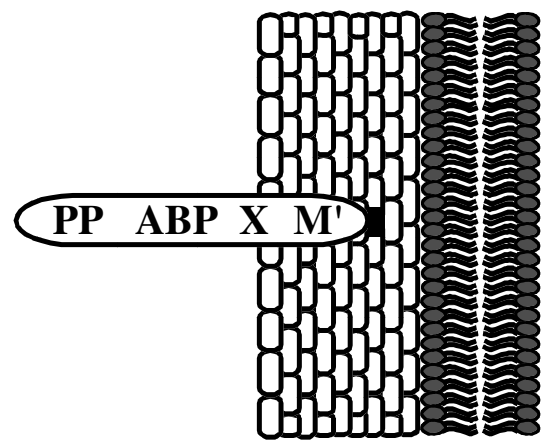

Figure 8. Novel expression vectors and their encoded gene product. (A) The novel display vectors pSCXs (6864 bp), pSCXm (7655 bp) and pSCX1 (8332 bp). Abbreviations: Bla, ß-lactamase encoding gene; $\mathrm{Cml}$, chloramphenicol acetyltransferase-encoding gene; OriE, origin of replication from E. coli; OriS, origin of replication from $S$. aureus; $\mathrm{P}_{\text {Lip }}$, S. hyicus promoter region designed for $S$. hyicus lipase production in S. carnosus. (B) Schematic picture of the processed gene fusion product illustrated as anchored to the cell surface. When a target gene is introduced into the multiple cloning sites of the vectors, the encoded target protein is exposed as illustrated anchored to the staphylococcal cell surface. $\mathrm{M}^{\prime}$ represents the processed and covalently anchored form of the $\mathrm{M}$ sequence of staphylococcal protein $\mathrm{A},(\mathrm{SpA})$. Note that the propeptide (PP) from S. hyicus is not processed in S. carnosus. 
In this study we addressed the stability issue and created three novel surface display vectors with an aim to generate a vector that would be more suitable for future library display applications. The rationale was to use to backbone of the structurally more stable S. xylosus system (Hansson et al., 1992) lacking the phage ori and combining it with the retained high surface density of expressed heterologous proteins characteristic for the S. carnosus display system (Samuelson et al., 1995; Andréoni et al., 1997). This was achieved basically by transferring the entire expression cassette from the $S$. carnosus vector to a modified $S$. xylosus vector. The main differences between the original expression vector, pSPPmABPXM, and the novel vectors, pSCX $s, \mathrm{pSCX} m$ and $\operatorname{pSCX} l$ depicted in Figure 8, are the following: (i) pSPPmABPXM contains an origin of replication for phage 11 that potentially could interfere with plasmid stability and replication in staphylococci and it has thus been deleted in the novel display vectors, (ii) the orientation of the $\beta$-lactamase encoding gene has been reversed, (iii) additional unique restriction sites have been added in the multiple cloning site (mcs) to make the vectors more versatile, (iv) the vector sizes have been decreased in pSCXs and $\mathrm{pSCX} m$ by deletion of a 677 bp region downstream of the surface display expression cassette, and in $\operatorname{pSCX} s$ by an additional deletion of a $791 \mathrm{bp}$ gene fragment upstream of the promoter, earlier postulated to have a positive effect on the expression levels when using the lipase promoter and signal sequence (Liebl and Götz, 1986).

Recombinant strains transformed with the $\mathrm{pSCX} s, \mathrm{pSCX} m$ or $\mathrm{pSCX} l$ plasmids, respectively, were analysed in terms of growth characteristics and vector stability as compared to $S$. carnosus cells transformed with the original vector pSPPmABPXM. Close to $100 \%$ of the analysed clones grew well when inoculated into liquid media and grown overnight. Also, plasmid preparations prepared from the overnight cultures demonstrated consistent band patterns in agarose gel electrophoresis suggesting that the phage $\mathrm{f} 1$ origin of replication was indeed responsible for the observed plasmid instability. This should be compared to recombinant staphylococci transformed with pSPPmABPXM where roughly $40 \%$ of the analysed clones grew well and only $20 \%$ of those yielding consistent plasmid band patterns while the remainder exhibited partial deletions and structural rearrangements. The inconsistency in bacterial growth for bacteria transformed with the pSPPmABPXM vector is likely to be related to the 

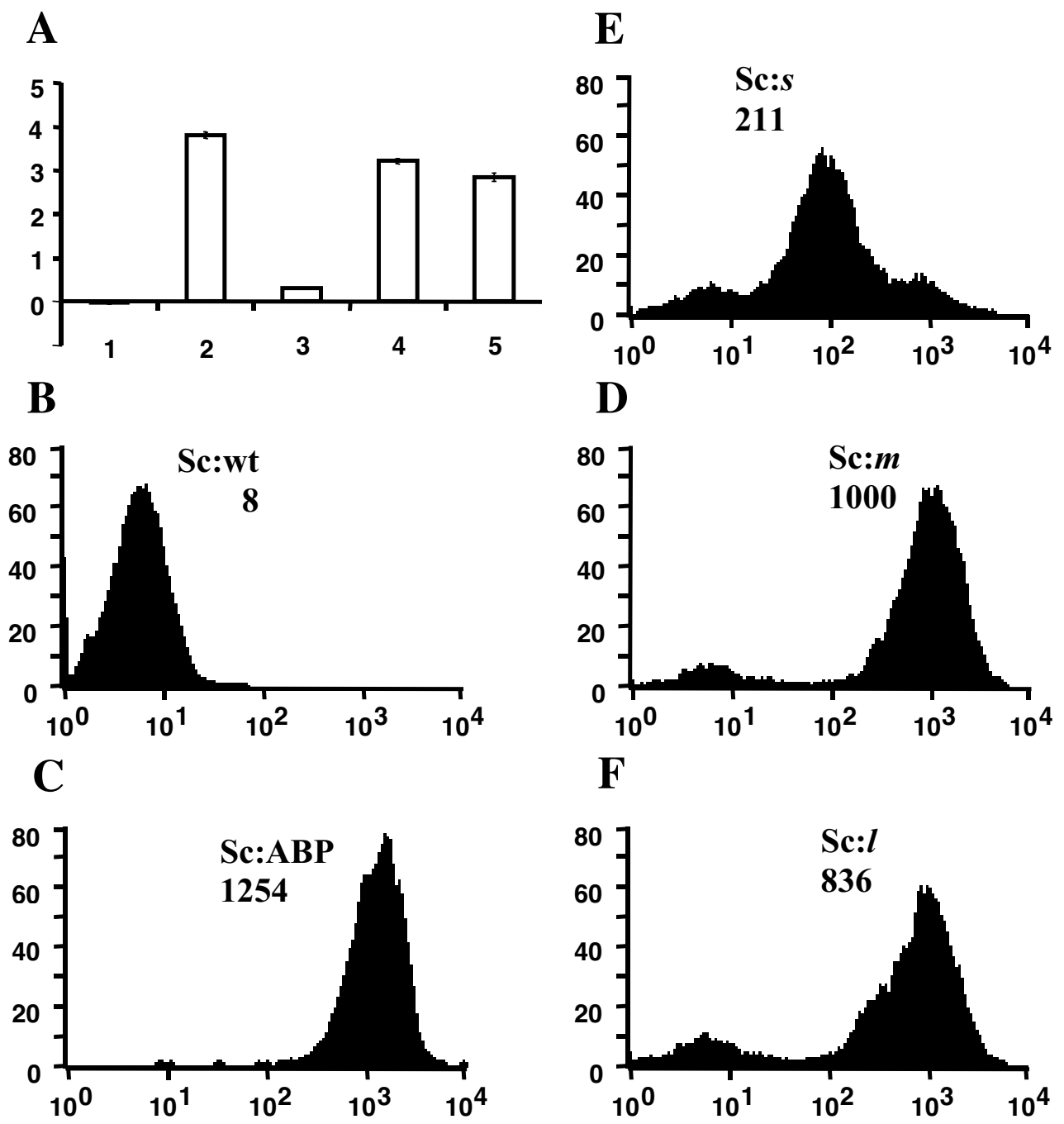

Figure 9. Panel (A) A comparative study in which representative cell populations of 1. wild type; and recombinant S. carnosus cells transformed with 2. pSPPmABPXM, 3. pSCXs, 4. pSCXm or 5. pSCX1, were analyzed according to the whole-cell colorimetric assay previously described. Panels (B) to $(\mathrm{F})$, flow cytometric analysis of wild type and recombinant $S$. carnosus cells, probed with an ABP-reactive mouse monoclonal antibody $13 \mathrm{~F} 10$, and stained with an Alexa-Fluor ${ }^{488}$ labelled rabbit-anti-mouse IgG. The histograms show non-stained bacterial cells displayed to the left in the histograms, and cells exposing ABP-containing surface proteins in an accessible form on their surface shifted to the right. The mean fluorescence reactivity and type of bacteria is given for each histogram. Fluorescence intensity is given on the $\mathrm{X}$-axis and the number of cells on the $\mathrm{Y}$-axis.

plasmid instability phenomenon and could for example be explained by deletions within the chloramphenicol resistance marker.

The novel vectors were also characterised for surface expression efficiency and accessibility of displayed molecules by the whole-cell colorimetric assay using the $\mathrm{ABP}$ moiety as a reporter for successful surface anchoring. The novel vectors showed rather equal surface expression efficiences within the groups, with the pSCXm and pSCXl vectors exhibiting a maintained high surface density of chimeric proteins 
comparable to the reference pSPPmABPXM transformed clone. However, cells transformed with pSCXs showed a substantial decrease in expressed surface proteins indicating that the deleted fragment upstream of the lipase promoter was indeed important for efficient surface expression. Flow cytometry has previously been used to quantify the number of surface displayed heterologous proteins on recombinant $S$. carnosus cells to approximately 10000 molecules per cell when using the pSPPmABPXM plasmid. Here we investigated the possibility of adapting flow cytometry as a general monitoring system in our efforts to improve the expression system. Wild-type and recombinant cells were labeled using a mouse monoclonal antibody, 13F10 (Andréoni et al., 1997), directed against the ABP region present in the novel vectors, combined with a fluorescently labeled rabbit anti-mouse IgG, and analysed on the flow cytometer. The results, presented in Figure 9, validated the previously performed enzymatic assay, indicating that cells transformed with the new $\mathrm{pSCX} m$ or $\mathrm{pSCX} l$ vectors respectively, exhibit a surface density of displayed reporter proteins comparable to the original pSPPmABPXM system. Also, the cells transformed with the pSCXs plasmid showed, in analogy with the colorimetric assay, a drastic decrease in expression efficiency, thus further demonstrating the importance of the upstream fragment when using the lipase promoter and signal peptide. The reason for this is unknown but could possibly be explained by the presence of additional bacterial promoter sequences upstream of the lipase promoter. However, upon sequence analysis of this region no strong bacterial promoter sequences could be identified. In summary, the newly developed plasmid vectors were genetically more stable than the original vector with maintained high expression levels making them more suitable for future flow cytometry based library selection strategies.

\section{Staphylococcal surface display for selection purposes (V)}

The successful engineering of our staphylococcal surface display system encouraged us to further evaluate the possibility of using also Gram-positive bacteria as a platform for future combinatorial protein engineering approaches. Gram-negative bacteria has previously been effectively used in this context (Georgiou, 2001), but gram-positive microorganisms possess several intrinsic properties that make them potentially more suitable for flow-cytometry based applications, including a thick peptidoglycan cell-wall making them more robust and able to withstand the high pressures and shear forces present in the flow cytometer (Pagan et al., 1999). 
Traditionally, the preferred format for selection of novel protein variants with specific ligand-binding properties has been phage-displayed antibody libraries (Holt et al., 2000). Effective display formats for antibodies are single-chain Fv fragments (McCafferty et al., 1990) and Fab fragments (Kang et al., 1991). More recently, also other protein scaffolds have been investigated as a source for novel affinity ligands (Nygren and Uhlén, 1997; Skerra, 2000). One such novel class of affinity proteins, denoted affibodies, based on the IgG-binding $\mathrm{Z}$ domain from $S$. aureus protein $\mathrm{A}$ has recently been described (Nord et al., 1997). A phage displayed combinatorial library was created through the simultaneous randomisation of thirteen surface located residues positioned within the Fc-binding surface, and the genetic fusion of this library to the coat protein III of the filamentous phage M13. This strategy has been successfully used for selection of affibodies to such diverse targets as Taq DNA polymerase, human recombinant factor VIII, a human apolipoprotein variant and the G protein of human respiratory syncytial virus (RSV) (Nord et al., 1997; Hansson et al., 1999; Nord et al., 2001). The same strategy has been employed to select affibody ligands also against human IgA and IgE, respectively (Gunneriusson et al., 1999b; Rönnmark et al., 2002). So far, phage display has been the preferred format for selection of affibodies but staphylococcal display of such libraries might be an attractive alternative since functional display of affibodies on $S$. carnosus already has been demonstrated (Gunneriusson et al., 1999b) and protocols for flow cytometrybased analysis exists (IV).

In this study, recombinant $S$. carnosus strains with surface exposed, engineered SpA domains, specific for IgG $\left(Z_{\mathrm{wt}}\right)$ (Nilsson et al., 1987) or the G protein of RSV $\left(\mathrm{Z}_{\mathrm{RSV} 1}\right)$ (Hansson et al., 1999) were created. The recombinant strains denoted Sc: $Z_{\mathrm{wT}}$ and $\mathrm{Sc}: \mathrm{Z}_{\mathrm{RSV} 1}$, respectively, were analyzed in a whole cell format and surface accessibility and retained functionality of the expressed proteins were demonstrated. Also, $\mathrm{Z}_{\mathrm{wt}}{ }^{-}$ expressing target cells could be sorted essentially quantitatively from a moderate excess of non-target $\mathrm{Z}_{\mathrm{RSV} 1}$-displaying control cells in a single sorting round using a high stringency sort mode. The robustness of staphylococcal cells in flow cytometry applications was proven since more than $95 \%$ of the sorted cells grow well on chloramphenicol plates after a single sorting round. 


\section{A}

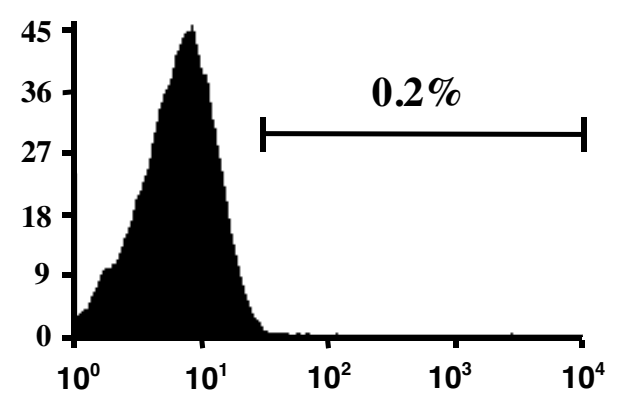

B

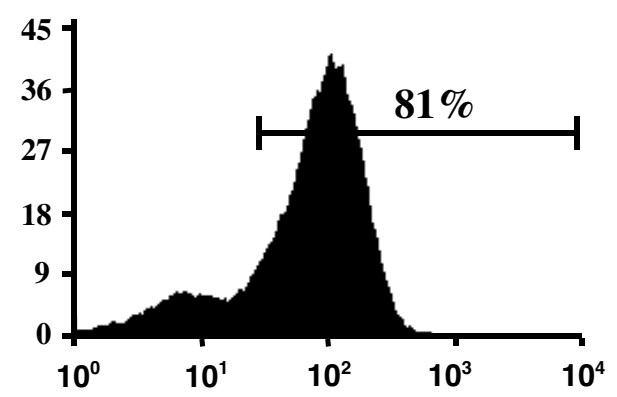

C

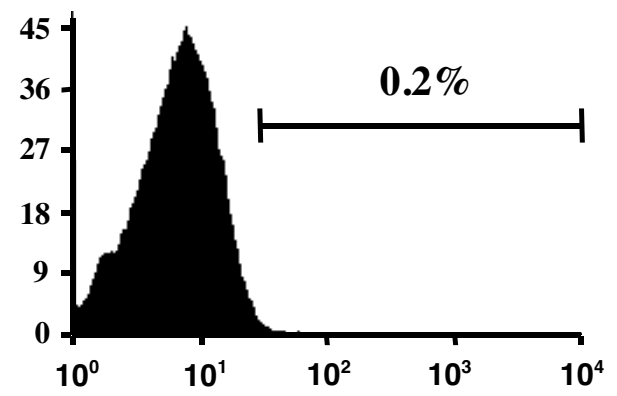

D
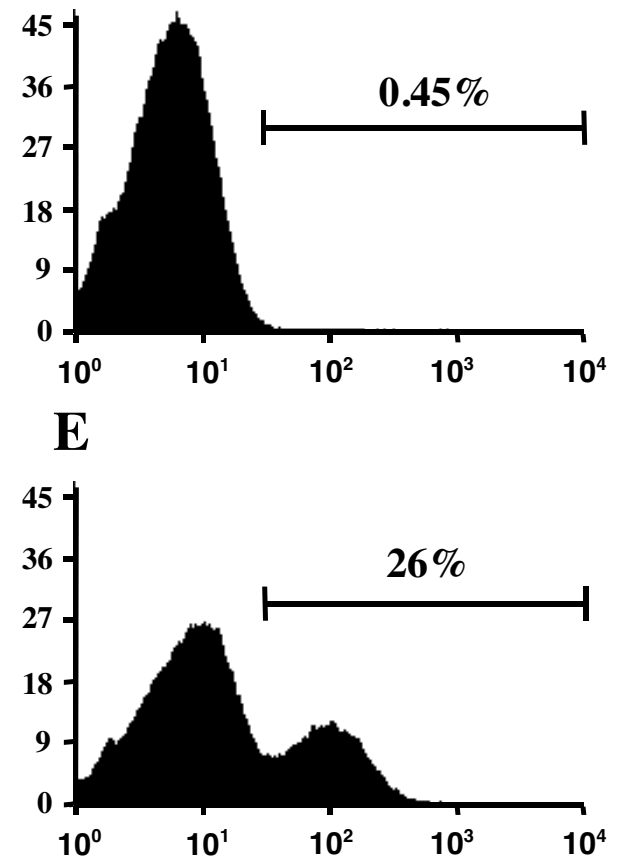

Figure 10. Histogram data from cell sorting experiments. Wild type and recombinant $S$. carnosus cells, were probed with biotinylated-IgG, and stained with an Alexa Fluor ${ }^{488}$-streptavidin conjugate. The bar in each graph represents the sort gate setting i. e. the minimum fluorescence intensity defined as a positive event. (A) $S c: Z_{\mathrm{RSV} 1}$ sample used as a negative control. (B) $\mathrm{Sc}: \mathrm{Z}_{\mathrm{wt}}$ sample used as a positive control. (C) A 1:100000 mixture of $S c: Z_{\mathrm{wt}}: S c: Z_{\mathrm{RSV} 1}$ cells analysed prior to the first cell sorting round. (D) 1:100000 mixture of $S c: Z_{\mathrm{w}}: S c: Z_{\mathrm{RSV} 1}$ cells recovered from the first cell sorting round.(E) 1:100000 mixture of $S c: Z_{\mathrm{wt}}: S c: Z_{\mathrm{RSV} 1}$ cells recovered from the second cell sorting round. The histograms show non-stained $S c: Z_{\mathrm{RSV} 1}$ bacterial cells displayed to the left in the histograms, and cells exposing $\mathrm{Z}_{\mathrm{wt}}$-containing proteins on their surface shifted to the right. Fluorescence intensity is given on the $\mathrm{X}$-axis and the number of cells on the $\mathrm{Y}$-axis.

In an effort to investigate the general applicability of this approach also for selection of very rare target cells from a large excess of non-target background cells we set up a simulated library selection experiment. A 1:100000 mixture of Sc: $Z_{\mathrm{wt}}$ target cells and $\mathrm{Sc}: \mathrm{Z}_{\mathrm{RSV} 1}$ control cells was incubated with biotinylated-IgG and Streptavidin-Alexa Fluor $^{488}$ conjugate and sorted on the basis of fluorescence. Since the number of 
positive cells in this experiment was very small a wide sort gate was set to make sure that no valuable target cells were lost. Approximately $0.2 \%$ of the control Sc: $Z_{\mathrm{RSV} 1}$ cells fell within the sorting window thus ensuring that most of the target cells were effectively sorted. The resulting fluorescence distributions after only two rounds of cell sorting with amplification steps in between are shown in Figure 10 together with positive and negative control populations (Figure 10). Approximately $26 \%$ of the cells fell within the positive sort window corresponding to a more than 25000 fold enrichment of rare target cells in only two rounds of cell sorting.

One important aspect when working with real library selections is the potential presence of unwanted secondary phenotypes such as elevated growth rates or expression levels and their effect on the selection procedure. This type of phenomenon could potentially lead to unwanted enrichment of non-target cells in the amplification step following fluorescence activated cell sorting. The effect of undesirable secondary phenotypes can be minimized by using inducible promoter systems (Daugherty et al., 1999). A previously described xylose-inducible, glucose repressible promoter system might be adapted to our S. carnosus display system (Wieland et al., 1995) to minimize this problem in the future. In this study the achieved enrichment of target cells is is not due to a growth advantage of the $\mathrm{Z}_{\mathrm{wt}}{ }^{-}$ expressing S. carnosus cells since repeated regrowth of the starting mixture without in between cell sorting did not result in any significant bias when analyzed by PCRscreening using $\mathrm{Z}_{\mathrm{wt}}$ specific primers. Briefly, staphylococcal cells with surface displayed $Z_{\mathrm{wt}}{ }^{-}$or $Z_{\mathrm{RSv} 1}$-affibodies were mixed at a 1:1 ratio and grown for 24 hours at $37^{\circ} \mathrm{C}$. An aliquot of the overnight culture was withdrawn and plated on chloramphenicol plates for subsequent PCR-screening using $\mathrm{Z}_{\mathrm{wt}}{ }^{-}$specific primer pairs. After three successive rounds of regrowth without cell-sorting no detectable bias due to growth advantages could be detected by the PCR-screening analysis.

In conclusion, the obtained results suggest that staphylococcal surface display of affibody libraries could be used together with flow cytometric cell sorting as an alternative to existing phage display technologies. In the future, it would be of obvious interest to investigate the capacity to discriminate also between cells expressing affibodies with only small differences in target affinity. The capability to discriminate between closely related binders is paramount for the successful selection 
of novel binders from surface displayed libraries. Also, the combination of cell surface display and flow cytometry offers the possibility of quantitative determination of binding kinetics in situ thus further increasing the usefulness of this technology platform. The drawback of using gram-positive bacteria is the generally lower rate of transformation, as compared to Gram-negative bacteria, and this area needs to be further investigated in the near future. However, transformation frequencies of $10^{5}-10^{6}$ colony forming units per $\mu \mathrm{g}$ of DNA have been reported for S. carnosus (Götz, 1990) being comparable to the libraries reported for yeast surface display systems (Wittrup, 2001). Also, if the libraries were to be used for affinity maturation strategies of known first generation binders this would circumvent the need for very large libraries thus making the gram-positive approach an attractive alternative to existing technologies.

\section{Future perspectives and concluding remarks}

The engineering of bacterial surfaces is currently an area of intense ongoing research with applications in many different areas of bioscience. We have described several areas where bacterial surface display could become useful for applied research in the near future. Bacteria with increased metal-binding capacity can be generated through surface display of metal-binding peptides. This type of bacteria could be used for sequestration of heavy-metals in bioremediation strategies. The use of combinatorial approaches provide means for generating tailor-made bacteria with increased specificity and affinity towards the target metal and would increase the usefulness of these types of bioadsorbents. Furthermore, if the cells could be effectively immobilized on solid supports, they would provide a convenient way of generating biofilters, biocatalysts or diagnostic devices. We have shown that directed immobilization on cotton fibers can be achieved through surface display of a cellulose binding domain from the filamentous fungii T. reseii on recombinant $S$. carnosus. Cellulose is a naturally abundant, chemically inert and non-toxic material thus offering an inexpensive immobilization matrix for this type of applications. Furthermore, the co-display of such immobilization anchors together with metalbinding peptides or enzymes can be effectively achieved either by co-expression as a fusion protein or by using two separate surface anchoring mechanisms for targeting the heterologous proteins to the cell surface. Perhaps the most exciting application 
area for bacterial surface display today is the expression of combinatorial protein libraries directly on cell surfaces for subsequent flow cytometry based selections of novel affinity pairs or enzymes with improved stability, activity or specificity. We have created a novel expression vector, potentially more suitable for library display applications, and demonstrated the feasibility of using this system for flow-cytometric enrichment of specific affibody expressing cells from a large background of nontarget expressing cells. It would therefore be of obvious interest to investigate if this strategy could be employed also for the display of whole affibody libraries for the subsequent selection of novel affinity partners. Here, the obvious bottleneck would be the overall lower transformation frequency that can be achieved compared to gramnegative bacteria and this topic needs to be further investigated in the future. However, transformation frequencies of $10^{5}-10^{6}$ colony forming units per $\mu \mathrm{g}$ of DNA have been observed for $S$. carnosus thus indicating that libraries of significant size could be envisioned also for gram-positive bacteria. A strategy to circumvent the need for very large libraries is to create biased, secondary libraries of known first generation binders, and to use these libraries for affinity maturation purposes. In summary, the general applicability of bacterial surface display have already been demonstrated for various biotechnological applications and recent findings suggest that it will continue to be an important tool for applied research also in the future. 


\section{Abbreviations}

\begin{tabular}{|c|c|}
\hline $\mathrm{ABP}$ & albumin binding protein derived from $\mathrm{SpG}$ \\
\hline AIDA-I & adhesin involved in diffuse adherence \\
\hline BCG & bacille Calmette-Guerin \\
\hline CBD & cellulose binding domain \\
\hline CMCase & carboxymethyl cellulase \\
\hline $\mathrm{CP}$ & cysteine containing peptide \\
\hline CSFV & classical swine fever virus \\
\hline СТB & cholera toxin B subunit \\
\hline CTBp & aa $50-75$ of CTB \\
\hline DNA & deoxyribonucleic acid \\
\hline FACS & fluorescence activated cell sorting \\
\hline FITC & fluorescein isothiocyanate \\
\hline FnBPB & fibronectin binding protein $\mathrm{B}$ \\
\hline FRET & fluorescence resonance energy transfer \\
\hline FSC & forward scatter \\
\hline GRAS & generally regarded as safe \\
\hline HIV & human immunodeficiency virus \\
\hline HP & histidine containing peptide \\
\hline HSA & human serum albumin \\
\hline $\operatorname{IgA}$ & immunoglobulin A \\
\hline $\operatorname{IgE}$ & immunoglobulin E \\
\hline IgG & immunoglobulin $\mathrm{G}$ \\
\hline i.d. & intradermal \\
\hline i.n. & intranasally \\
\hline i.p. & intraperitoneally \\
\hline i.v. & intravenously \\
\hline INP & ice nucleation protein \\
\hline Inv & invasin protein \\
\hline Lpp & major lipoprotein \\
\hline $\mathrm{Lpp}^{\prime}$ & N-terminal signal peptide + first 9 aa of Lpp \\
\hline Lpp'OmpA & a chimerae of $\mathrm{Lpp}^{\prime}$ and parts of OmpA \\
\hline mcs & multiple cloning site \\
\hline MT & metallothionein \\
\hline Omp & outer membrane protein \\
\hline $\mathrm{OPH}$ & organophosphorous hydrolase \\
\hline PAL & peptidoglycan associated lipoprotein \\
\hline $\mathrm{PC}$ & phytochelatin \\
\hline PCR & polymerase chain reaction \\
\hline PE & phycoerythrin \\
\hline PP & propeptide from $S$. hyicus lipase \\
\hline RSV & respiratory cyncytial virus \\
\hline S & signal peptide \\
\hline $\mathrm{scFv}$ & single chain fragment variable \\
\hline $\mathrm{SpA}$ & staphylococcal protein A \\
\hline $\mathrm{SpG}$ & staphylococcal protein $\mathrm{G}$ \\
\hline SSC & side scatter \\
\hline TTFC & tetanus toxin fragment $\mathrm{C}$ \\
\hline $\mathrm{Z}$ & protein variant derived from the B domain of SpA \\
\hline
\end{tabular}




\section{Acknowledgements}

Puh...... I did it! Följande personer har genom sina insatser en stor del i tillkomsten av denna avhandling. Tack! Jag glömmer det aldrig.

Stefan, för att jag fick stanna kvar trots att du redan då tänkte ta det lite lugnare. Saker som uppskattats enormt är din fantastiska och oöverträffade förmåga att få pek accepterade, din oändliga positivism, gästfrihet, ypperliga musiksmak (Speciellt din högst personliga tolkning av Can't you hear me knocking klockan 02.00) samt din insikt att flödescytometri lär man sig bäst i Texas, så det är bäst att du åker dit inte bara en gång utan två! Välkommen tillbaka, nu kan du stryka mig från akutlistan!

Mathias, för stora visioner och ett positivt tänkande som genomsyrar hela DNAcorner $^{\mathrm{TM}}$, samt din förmåga att entusiasmera allt och alla omkring dig och få oss att tro att saker och ting faktiskt är genomförbara.

Tack också till alla andra, nuvarande och föredetta kollegor, vid institutionen för Bioteknologi och speciellt DNAcorner ${ }^{\mathrm{TM}}$. Ni har gjort det till en sann glädje att gå till jobbet! (Ok, hösten 2001 var lite seg, men det berodde inte på er.) Många och glada är alla minnen av förfester, fester, efterfester, fredagsbarer, K9 Corps (R.I.P.), innebandy, sabai sabai, idre, solskenet, laser dome, pellegrino, colahäv, musikkvällar, resor till Väddö, Sandhamn, Gotland, Åre, Los Angeles, Madrid, Berlin, San Diego och Austin. Ett alldeles speciellt tack till följande personer:

Christin, för att du tog hand om mig när jag var ny och grön på labbet och för att du fortsätter att ta hand om mig. Fast det är klart, med Stefan som handledare borde vi ha fattat hur det skulle gå!

Patrik, Ja vad ska man säga? Det är något visst med skägg! Tack för att du lärt mig allt du kan om staffar, protoplaster och annat viktigt som man inte klarar sig utan här i världen, såsom biljardkvällar på "Texas showdown", mexican martinis på "Trudys" plus sköna margaruitakvällar hos "Manuels". Du är en riktigt hyvens prick!

Janne, för framgångsrikt staffstuff. Det räddade oss båda! Men framför allt för tennisluncher, businessluncher, drinkkvällar, 27/6-firande, provkörningar och Bermuda kvällar. Och du, nu behöver jag inte "winning ugly" längre. Det är ett trendbrott!!!! Tack kompis!

Sophia, Min reskompis! För att du visat mig att spärrar är till för att forceras, och för allt ditt slit med vardagsproblemen på labbet. Keep up the good work! Det är uppskattat.

Ett stort tack också till Olof för din heroiska insats i samband med FACS köpet, och för ditt osjälviska slit med allt annat som måste göras. Dessutom är du en "värsting" till DJ, med fler hyllmeter dyr vinyl än någon annan jag känner.

Mina underbara bänkgrannar genom åren: Marianne för ditt hjärtliga välkomnande för en sisådär 5 år sedan, och för fantastiskt trevligt labsällskap. Amelie; för att du inte bara lyckades ersätta Marianne utan dessutom tillfört nya fräscha idéer och tankar på labbet. Mer sånt! 
Naturligtvis ett speciellt tack till mina beresta rumskompisar i "Hall of fame": Jocke W, Peru-san och Maria W.

Jag vill också passa på att tacka K93-gruppen: Martin, Stoffe, Stina, Anna B för nästan 10 års samvaro, med Indien som en självklar formtopp. Maharadja Mac!

Jerker, Peter och alla andra kompisar från verkligheten, som jag naturligtvis har försummat än mer än vanligt på sista tiden, för att ni ger mig inblick i livet efter detta.

Christin - min älskling.

Min familj, för ovärderlig marksupport, speciellt så här på sluttampen, och för att ni gett mig förutsättningar att lyckas i livet.

NUTEK (Immunoteknologi programmet) och Stiftelsen för strategisk forskning (SSF) tackas för ekonomiskt stöd. 


\section{References}

Abrahmsén, L., Moks, T., Nilsson, B., Hellman, U. and Uhlén, M. (1985) Analysis of signals for secretion in the staphylococcal protein A gene. EMBO J. 4, 3901-3906.

Acheson, D.W.K., Sonenshein, A.L., Leong, J.M. and Keusch, G.T. (1997) Heatstable Spore-based Vaccines: Surface expression of Invasin-Cell wall fusion proteins in Bacillus subtilis. In: F. Brown, D. Burton, P. Doherty, J. Mekalanos and E. Norrby (Eds), Vaccines 97. Cold Spring Harbor Laboratory Press. N.Y., New York, p. 179184.

Agterberg, M., Adriaanse, H. and Tommassen, J. (1987) Use of the outer membrane protein PhoE as a carrier for the transport of a foreign antigenic determinant to the cell surface of Escherichia coli K-12. Gene 59, 145-150.

Agterberg, M., Adriaanse, H., Lankhof, H., Meloen, R. and Tommassen, J. (1990) Outer membrane PhoE protein of Escherichia coli as a carrier for foreign antigenic determinants: immunogenicity of epitopes of foot-and-mouth disease virus. Vaccine 8, 85-91.

Aho, S., Olkkonen, V., Jalava, T., Paloheimo, M., Buhler, R., Niku-Paavola, M.L., Bamford, D.H. and Korhola, M. (1991) Monoclonal antibodies against core and cellulose-binding domains of Trichoderma reesei cellobiohydrolases I and II and endoglucanase I. Eur. J. Biochem. 200, 643-649.

Andréoni, C., Goetsch, L., Libon, C., Samuelson, P., Nguyen, T.N., Robert, A., Uhlén, M., Binz, H. and Ståhl, S. (1997) Flow cytometric quantification of surfacedisplayed recombinant receptors on staphylococci. Biotechniques 23, 696-702, 704.

Bae, W., Chen, W., Mulchandani, A. and Mehra, R.K. (2000) Enhanced bioaccumulation of heavy metals by bacterial cells displaying synthetic phytochelatins. Biotechnol. Bioeng. 70, 518-524.

Bae, W., Mulchandani, A. and Chen, W. (2002) Cell surface display of synthetic phytochelatins using ice nucleation protein for enhanced heavy metal bioaccumulation. J. Inorg. Biochem. 88, 223-227.

Ballester, S., Lopez, P., Espinosa, M., Alonso, J.C. and Lacks, S.A. (1989) Plasmid structural instability associated with pC194 replication functions. J. Bacteriol. 171, 2271-2277.

Barry, M.A., Dower, W.J. and Johnston, S.A. (1996) Toward cell-targeting gene therapy vectors: selection of cell-binding peptides from random peptide-presenting phage libraries. Nat. Med. 2, 299-305.

Bassi, A.S., Ding, D.N., Gloor, G.B. and Margaritis, A. (2000) Expression of single chain antibodies (scFvs) for c-myc oncoprotein in recombinant Escherichia coli membranes by using the ice-nucleation protein of Pseudomonas syringae. Biotechnol. Prog. 16, 557-563.

Benhar, I. (2001) Biotechnological applications of phage and cell display. Biotechnology Advances 19, 1-33.

Bliska, J.B. and Falkow, S. (1984) Interplay between determinants of cellular entry and cellular disruption in the enteropathogenic Yersinia. Curr. Opin. Infect. Dis. 7, 323-328. 
Boder, E.T., Midelfort, K.S. and Wittrup, K.D. (2000) Directed evolution of antibody fragments with monovalent femtomolar antigen-binding affinity. Proc. Natl. Acad. Sci. U S A 97, 10701-10705.

Boder, E.T. and Wittrup, K.D. (1998) Optimal screening of surface-displayed polypeptide libraries. Biotechnol. Prog. 14, 55-62.

Boder, E.T. and Wittrup, K.D. (2000) Yeast surface display for directed evolution of protein expression, affinity, and stability. Methods Enzymol. 328, 430-444.

Brown, S. (1997) Metal-recognition by repeating polypeptides. Nat. Biotechnol. 15, 269-272.

Brown, C.K., Modzelewski, R.A., Johnson, C. and Wong, M.K. (2000) A novel approach for the identification of unique tumor vasculature binding peptides using an Escherichia coli peptide display library. Ann. Surg. Oncol. 7, 743-749.

Cano, F., Liljeqvist, S., Nguyen, T.N., Samuelson, P., Bonnefoy, J.Y., Ståhl, S. and Robert, A. (1999) A surface-displayed cholera toxin B peptide improves antibody responses using food-grade staphylococci for mucosal subunit vaccine delivery. FEMS Immunol. Med. Microbiol. 25, 289-298.

Cano, F., Plotnicky-Gilquin, H., Nguyen, T.N., Liljeqvist, S., Samuelson, P., Bonnefoy, J., Ståhl, S. and Robert, A. (2000) Partial protection to respiratory syncytial virus (RSV) elicited in mice by intranasal immunization using live staphylococci with surface-displayed RSV-peptides. Vaccine 18, 2743-2752.

Charbit, A., Boulain, J.C., Ryter, A. and Hofnung, M. (1986) Probing the topology of a bacterial membrane protein by genetic insertion of a foreign epitope; expression at the cell surface. Embo J. 5, 3029-3037.

Charbit, A., Molla, A., Saurin, W. and Hofnung, M. (1988) Versatility of a vector for expressing foreign polypeptides at the surface of gram-negative bacteria. Gene 70 , 181-189.

Chen, G., Cloud, J., Georgiou, G. and Iverson, B.L. (1996) A quantitative immunoassay utilizing Escherichia coli cells possessing surface-expressed single chain Fv molecules. Biotechnol. Prog. 12, 572-574.

Chen, W. and Georgiou, G. (2002) Cell-Surface display of heterologous proteins: From high-throughput screening to environmental applications. Biotechnol. Bioeng. 79, 496-503.

Cho, C.M., Mulchandani, A. and Chen, W. (2002) Bacterial cell surface display of organophosphorus hydrolase for selective screening of improved hydrolysis of organophosphate nerve agents. Appl. Environ. Microbiol. 68, 2026-2030.

Christmann, A., Walter, K., Wentzel, A., Kratzner, R. and Kolmar, H. (1999) The cystine knot of a squash-type protease inhibitor as a structural scaffold for Escherichia coli cell surface display of conformationally constrained peptides. Protein Eng. 12, 797-806.

Christmann, A., Wentzel, A., Meyer, C., Meyers, G. and Kolmar, H. (2001) Epitope mapping and affinity purification of monospecific antibodies by Escherichia coli cell surface display of gene-derived random peptide libraries. J. Immunol. Methods 257, 163-173. 
Daugherty, P.S., Chen, G., Olsen, M.J., Iverson, B.L. and Georgiou, G. (1998) Antibody affinity maturation using bacterial surface display. Protein Eng. 11, 825832 .

Daugherty, P.S., Iverson, B.L. and Georgiou, G. (2000) Flow cytometric screening of cell-based libraries. J. Immunol. Methods 243, 211-227.

Daugherty, P.S., Olsen, M.J., Iverson, B.L. and Georgiou, G. (1999) Development of an optimized expression system for the screening of antibody libraries displayed on the Escherichia coli surface. Protein Eng. 12, 613-621.

de Boer, E.C., Bevers, R.F., Kurth, K.H. and Schamhart, D.H. (1996) Double fluorescent flow cytometric assessment of bacterial internalization and binding by epithelial cells. Cytometry 25, 381-387.

Delmas, A. and Partidos, C.D. (1996) The binding of chimeric peptides to GM1 ganglioside enables induction of antibody responses after intranasal immunization. Vaccine 14, 1077-1082.

Demleitner, G. and Götz, F. (1994) Evidence for importance of the Staphylococcus hyicus lipase pro-peptide in lipase secretion, stability and activity. FEMS Microbiol. Lett. 121, 189-197.

Dertzbaugh, M.T. (1998) Genetically engineered vaccines: an overview. Plasmid 39, 100-113.

Dieye, Y., Usai, S., Clier, F., Gruss, A. and Piard, J.C. (2001) Design of a proteintargeting system for lactic acid bacteria. J. Bacteriol. 183, 4157-4166.

Donovan, W., Zheng, L.B., Sandman, K. and Losick, R. (1987) Genes encoding spore coat polypeptides from Bacillus subtilis. J. Mol. Biol. 196, 1-10.

Dower, W.J. and Mattheakis, L.C. (2002) In vitro selection as a powerful tool for the applied evolution of proteins and peptides. Curr. Opin. Chem. Biol. 6, 390-398.

Edelman, R., Palmer, K., Russ, K.G., Secrest, H.P., Becker, J.A., Bodison, S.A., Perry, J.G., Sills, A.R., Barbour, A.G., Luke, C.J., Hanson, M.S., Stover, C.K., Burlein, J.E., Bansal, G.P., Connor, E.M. and Koenig, S. (1999) Safety and immunogenicity of recombinant Bacille Calmette-Guerin (rBCG) expressing Borrelia burgdorferi outer surface protein A (OspA) lipoprotein in adult volunteers: a candidate Lyme disease vaccine. Vaccine 17, 904-914.

Ernst, W., Grabherr, R., Wegner, D., Borth, N., Grassauer, A. and Katinger, H. (1998) Baculovirus surface display: construction and screening of a eukaryotic epitope library. Nucleic Acids Res. 26, 1718-1723.

Etz, H., Minh, D.B., Schellack, C., Nagy, E. and Meinke, A. (2001) Bacterial phage receptors, versatile tools for display of polypeptides on the cell surface. J. Bacteriol. 183, 6924-6935.

Fadda, S., Lebert, A., Leroy-Setrin, S. and Talon, R. (2002) Decarboxylase activity involved in methyl ketone production by Staphylococcus carnosus 833, a strain used in sausage fermentation. FEMS Microbiol. Lett. 210, 209-214.

Fischetti, V.A., Medaglini, D. and Pozzi, G. (1996) Gram-positive commensal bacteria for mucosal vaccine delivery. Curr. Opin. Biotechnol. 7, 659-666. 
Fischetti, V.A., Pancholi, V. and Schneewind, O. (1990) Conservation of a hexapeptide sequence in the anchor region of surface proteins from gram-positive cocci. Mol. Microbiol. 4, 1603-1605.

Francisco, J.A., Campbell, R., Iverson, B.L. and Georgiou, G. (1993a) Production and fluorescence-activated cell sorting of Escherichia coli expressing a functional antibody fragment on the external surface. Proc. Natl. Acad. Sci. U S A 90, 1044410448 .

Francisco, J.A., Earhart, C.F. and Georgiou, G. (1992) Transport and anchoring of beta-lactamase to the external surface of Escherichia coli. Proc. Natl. Acad. Sci. U S A 89, 2713-2717.

Francisco, J.A., Stathopoulos, C., Warren, R.A., Kilburn, D.G. and Georgiou, G. (1993b) Specific adhesion and hydrolysis of cellulose by intact Escherichia coli expressing surface anchored cellulase or cellulose binding domains. Biotechnology 11, 491-495.

Freudl, R., MacIntyre, S., Degen, M. and Henning, U. (1986) Cell surface exposure of the outer membrane protein OmpA of Escherichia coli K-12. J. Mol. Biol. 188, 491494.

Fuchs, P., Breitling, F., Dubel, S., Seehaus, T. and Little, M. (1991) Targeting recombinant antibodies to the surface of Escherichia coli: fusion to a peptidoglycan associated lipoprotein. Biotechnology 9, 1369-1372.

Fuchs, P., Weichel, W., Dubel, S., Breitling, F. and Little, M. (1996) Separation of E. coli expressing functional cell-wall bound antibody fragments by FACS. Immunotechnology 2, 97-102.

Georgiou, G. (2001) Analysis of large libraries of protein mutants using flow cytometry. Adv. Prot. Chem. 55, 293-315.

Georgiou, G., Stathopoulos, C., Daugherty, P.S., Nayak, A.R., Iverson, B.L. and Curtiss, R., 3rd. (1997) Display of heterologous proteins on the surface of microorganisms: from the screening of combinatorial libraries to live recombinant vaccines. Nat. Biotechnol. 15, 29-34.

Götz, F. (1986) Ein neues Wirt-Vektor-System bei Staphylococcus carnosus. Die Umschau 10, 530-537.

Götz, F. (1990) Staphylococcus carnosus: a new host organism for gene cloning and protein production. Soc. Appl. Bacteriol. Symp. Ser. 19, 49S-53S.

Gunneriusson, E., Nord, K., Uhlén, M. and Nygren, P.-Å. (1999a) Affinity maturation of a Taq DNA polymerase specific affibody by helix shuffling. Protein Eng. 12, 873878.

Gunneriusson, E., Samuelson, P., Ringdahl, J., Grönlund, H., Nygren, P.-A. and Ståhl, S. (1999b) Staphylococcal surface display of immunoglobulin A (IgA)- and IgE- specific in vitro-selected binding proteins (affibodies) based on Staphylococcus aureus protein A. Appl. Environ. Microbiol. 65, 4134-4140.

Gunneriusson, E., Samuelson, P., Uhlén, M., Nygren, P.-Å. and Ståhl, S. (1996) Surface display of a functional single-chain Fv antibody on staphylococci. $J$. Bacteriol. 178, 1341-1346. 
Guss, B., Uhlén, M., Nilsson, B., Lindberg, M., Sjöquist, J. and Sjödahl, J. (1984) Region X, the cell-wall-attachment part of staphylococcal protein A. Eur. J. Biochem. $138,413-420$.

Haddad, D., Liljeqvist, S., Kumar, S., Hansson, M., Ståhl, S., Perlmann, H., Perlmann, P. and Berzins, K. (1995) Surface display compared to periplasmic expression of a malarial antigen in Salmonella typhimurium and its implications for immunogenicity. FEMS Immunol. Med. Microbiol. 12, 175-186.

Hammes, W.P., Bosch, I. and Wolf, G. (1995) Contribution of Staphylococcus carnosus and Staphylococcus piscifermentans to the fermentation of protein foods. $J$. Appl. Bacteriol. Sym. Suppl.79, 76S-83S.

Hanes, J. and Pluckthun, A. (1997) In vitro selection and evolution of functional proteins by using ribosome display. Proc. Natl. Acad. Sci. U S A 94, 4937-4942.

Hansson, M., Ringdahl, J., Robert, A., Power, U., Goetsch, L., Nguyen, T.N., Uhlén, M., Ståhl, S. and Nygren, P.-Å. (1999) An in vitro selected binding protein (affibody) shows conformation- dependent recognition of the respiratory syncytial virus (RSV) $\mathrm{G}$ protein. Immunotechnology 4, 237-252.

Hansson, M., Samuelson, P., Gunneriusson, E. and Ståhl, S. (2001) Surface display on gram positive bacteria. Comb. Chem. High. Throughput. Screen. 4, 171-184.

Hansson, M., Samuelson, P., Nguyen, T.N. and Ståhl, S. (2002) General expression vectors for Staphylococcus carnosus enabled efficient production of the outer membrane protein A of Klebsiella pneumoniae. FEMS Microbiol. Lett. 210, 263-270.

Hansson, M., Ståhl, S., Nguyen, T.N., Bachi, T., Robert, A., Binz, H., Sjölander, A. and Uhlén, M. (1992) Expression of recombinant proteins on the surface of the coagulase-negative bacterium Staphylococcus xylosus. J. Bacteriol. 174, 4239-4245.

Harrison, J.L., Taylor, I. and O'Connor, C. (1990) Presentation of foreign antigenic determinants at the bacterial cell surface using the TraT lipoprotein. Res. Microbiol. 141, 1009-1012.

Hedegaard, L. and Klemm, P. (1989) Type 1 fimbriae of Escherichia coli as carriers of heterologous antigenic sequences. Gene 85, 115-124.

Henderson, I.R., Cappello, R. and Nataro, J.P. (2000) Autotransporter proteins, evolution and redefining protein secretion: response. Trends Microbiol. 8, 534-535.

Henderson, I.R., Navarro-Garcia, F. and Nataro, J.P. (1998) The great escape: structure and function of the autotransporter proteins. Trends Microbiol. 6, 370-378.

Holler, P.D., Holman, P.O., Shusta, E.V., O'Herrin, S., Wittrup, K.D. and Kranz, D.M. (2000) In vitro evolution of a $\mathrm{T}$ cell receptor with high affinity for peptide/MHC. Proc. Natl. Acad. Sci. U S A 97, 5387-5392.

Holt, L.J., Enever, C., de Wildt, R.M. and Tomlinson, I.M. (2000) The use of recombinant antibodies in proteomics. Curr. Opin. Biotechnol. 11, 445-449.

Holzem, A., Nahring, J.M. and Fischer, R. (2001) Rapid identification of a tobacco mosaic virus epitope by using a coat protein gene-fragment-pVIII fusion library. $J$. Gen. Virol. 82, 9-15. 
Isticato, R., Cangiano, G., Tran, H.T., Ciabattini, A., Medaglini, D., Oggioni, M.R., De Felice, M., Pozzi, G. and Ricca, E. (2001) Surface display of recombinant proteins on Bacillus subtilis spores. J. Bacteriol. 183, 6294-6301.

Jennings, P.A., Bills, M.M., Irving, D.O. and Mattick, J.S. (1989) Fimbriae of Bacteroides nodosus: protein engineering of the structural subunit for the production of an exogenous peptide. Protein Eng. 2, 365-369.

Jeong, H., Yoo, S. and Kim, E. (2001) Cell surface display of salmobin, a thrombinlike enzyme from Agkistrodon halys venom on Escherichia coli using ice nucleation protein. Enzyme Microb. Technol. 28, 155-160.

Jung, H.C., Lebeault, J.M. and Pan, J.G. (1998) Surface display of Zymomonas mobilis levansucrase by using the ice- nucleation protein of Pseudomonas syringae. Nat. Biotechnol. 16, 576-580.

Jung, H.C., Park, J.H., Park, S.H., Lebeault, J.M. and Pan, J.G. (1998) Expression of carboxymethylcellulase on the surface of Escherichia coli using Pseudomonas syringae ice nucleation protein. Enzyme Microb. Technol. 22, 348-354.

Kang, A.S., Barbas, C.F., Janda, K.D., Benkovic, S.J. and Lerner, R.A. (1991) Linkage of recognition and replication functions by assembling combinatorial antibody Fab libraries along phage surfaces. Proc. Natl. Acad. Sci. U S A 88, 43634366.

Kelemen, M.V. and Sharpe, J.E. (1979) Controlled cell disruption: a comparison of the forces required to disrupt different micro-organisms. J. Cell Sci. 35, 431-441.

Kim, Y.S., Jung, H.C. and Pan, J.G. (2000) Bacterial cell surface display of an enzyme library for selective screening of improved cellulase variants. Appl. Environ. Microbiol. 66, 788-793.

Kjaergaard, K., Hasman, H., Schembri, M.A. and Klemm, P. (2002) Antigen 43mediated autotransporter display, a versatile bacterial cell surface presentation system. J. Bacteriol. 184, 4197-4204.

Kjaergaard, K., Schembri, M.A. and Klemm, P. (2001) Novel Zn(2+)-chelating peptides selected from a fimbria-displayed random peptide library. Appl. Environ. Microbiol. 67, 5467-5473.

Klauser, T., Pohlner, J. and Meyer, T.F. (1990) Extracellular transport of cholera toxin B subunit using Neisseria IgA protease beta-domain: conformation-dependent outer membrane translocation. Embo J. 9, 1991-1999.

Klauser, T., Pohlner, J. and Meyer, T.F. (1992) Selective extracellular release of cholera toxin B subunit by Escherichia coli: dissection of Neisseria Iga beta-mediated outer membrane transport. Embo J. 11, 2327-2335.

Klauser, T., Pohlner, J. and Meyer, T.F. (1993) The secretion pathway of IgA protease-type proteins in gram-negative bacteria. Bioassays 15, 799-805.

Klemm, P. and Schembri, M.A. (2000a) Bacterial adhesins: function and structure. Int. J. Med. Microbiol. 290, 27-35.

Klemm, P. and Schembri, M.A. (2000b) Fimbrial surface display systems in bacteria: from vaccines to random libraries. Microbiology $146 \mathrm{Pt}$ 12, 3025-3032. 
Koebnik, R., Locher, K.P. and Van Gelder, P. (2000) Structure and function of bacterial outer membrane proteins: barrels in a nutshell. Mol. Microbiol. 37, 239-253.

Konieczny, M.P., Suhr, M., Noll, A., Autenrieth, I.B. and Alexander Schmidt, M. (2000) Cell surface presentation of recombinant (poly-) peptides including functional T-cell epitopes by the AIDA autotransporter system. FEMS Immunol. Med. Microbiol. 27, 321-332.

Kornacker, M.G. and Pugsley, A.P. (1990) The normally periplasmic enzyme betalactamase is specifically and efficiently translocated through the Escherichia coli outer membrane when it is fused to the cell-surface enzyme pullulanase. Mol. Microbiol. 4, 1101-1109.

Kotrba, P., Doleckova, L., de Lorenzo, V. and Ruml, T. (1999a) Enhanced bioaccumulation of heavy metal ions by bacterial cells due to surface display of short metal binding peptides. Appl. Environ. Microbiol. 65, 1092-1098.

Kotrba, P., Pospisil, P., de Lorenzo, V. and Ruml, T. (1999b) Enhanced metallosorption of Escherichia coli cells due to surface display of beta- and alphadomains of mammalian metallothionein as a fusion to LamB protein. J. Recept. Signal Transduct. Res. 19, 703-715.

Kronvall, G. and Williams, R.C., Jr. (1969) Differences in anti-protein A activity among IgG subgroups. J. Immunol. 103, 828-833.

Kuwajima, G. (1988) Construction of a minimum-size functional flagellin of Escherichia coli. J. Bacteriol. 170, 3305-3309.

Langermann, S., Palaszynski, S., Sadziene, A., Stover, C.K. and Koenig, S. (1994) Systemic and mucosal immunity induced by BCG vector expressing outer-surface protein A of Borrelia burgdorferi. Nature 372, 552-555.

Langone, J.J. (1982) Applications of immobilized protein A in immunochemical techniques. J. Immunol. Methods 55, 277-296.

Lattemann, C.T., Maurer, J., Gerland, E. and Meyer, T.F. (2000) Autodisplay: functional display of active beta-lactamase on the surface of Escherichia coli by the AIDA-I autotransporter. J. Bacteriol. 182, 3726-3733.

LeBaron, H.M., Mumma, R.O. and Honeycutt. (1999) Continous degradation of phenol at low concentration using immobilized Pseudomonas putida. Enzyme Microb. Technol., 530-536.

Leclerc, C., Charbit, A., Martineau, P., Deriaud, E. and Hofnung, M. (1991) The cellular location of a foreign $\mathrm{B}$ cell epitope expressed by recombinant bacteria determines its $\mathrm{T}$ cell-independent or T cell-dependent charcteristics. J. Immunol. 147, 3545-3552.

Lee, S.F., Halperin, S.A., Wang, H. and MacArthur, A. (2002) Oral colonization and immune responses to Streptococcus gordonii expressing a pertussis toxin S1 fragment in mice. FEMS Microbiol. Lett. 208, 175-178.

Lee, S.F., March, R.J., Halperin, S.A., Faulkner, G. and Gao, L. (1999) Surface expression of a protective recombinant pertussis toxin $\mathrm{S} 1$ subunit fragment in Streptococcus gordonii. Infect. Immun. 67, 1511-1516. 
Lehtiö, J., Teeri, T.T. and Nygren, P.- $\AA$. (2000) Alpha-amylase inhibitors selected from a combinatorial library of a cellulose binding domain scaffold. Proteins 41, 316322 .

Leong, J.M., Fournier, R.S. and Isberg, R.R. (1990) Identification of the integrin binding domain of the Yersinia pseudotuberculosis invasin protein. Embo J. 9, 19791989.

Liebl, W. and Götz, F. (1986) Studies on lipase directed export of Escherichia coli beta-lactamase in Staphylococcus carnosus. Mol. Gen. Genet. 204, 166-173.

Liepe, H.-U. (1982) Bakterienkulturen und Rohwurst. Forum Mikrobiologie 5.

Liljeqvist, S., Cano, F., Nguyen, T.N., Uhlén, M., Robert, A. and Ståhl, S. (1999) Surface display of functional fibronectin-binding domains on Staphylococcus carnosus. FEBS Lett. 446, 299-304.

Liljeqvist, S., Samuelson, P., Hansson, M., Nguyen, T.N., Binz, H. and Ståhl, S. (1997a) Surface display of the cholera toxin B subunit on Staphylococcus xylosus and Staphylococcus carnosus. Appl. Environ. Microbiol. 63, 2481-2488.

Liljeqvist, S. and Ståhl, S. (1999) Production of recombinant subunit vaccines: protein immunogens, live delivery systems and nucleic acid vaccines. J. Biotechnol. 73, 1-33.

Liljeqvist, S., Ståhl, S., Andréoni, C., Binz, H., Uhlén, M. and Murby, M. (1997b) Fusions to the cholera toxin B subunit: influence on pentamerization and GM1 binding. J. Immunol. Methods 210, 125-135.

Linder, M., Nevanen, T., Söderholm, L., Bengs, O. and Teeri, T.T. (1998) Improved immobilization of fusion proteins via cellulose-binding domains. Biotechnol. Bioeng. 60, 642-647.

Linder, M., Nevanen, T. and Teeri, T.T. (1999) Design of a pH-dependent cellulosebinding domain. FEBS Lett. 447, 13-6.

Linder, M. and Teeri, T.T. (1996) The cellulose-binding domain of the major cellobiohydrolase of Trichoderma reesei exhibits true reversibility and a high exchange rate on crystalline cellulose. Proc. Natl. Acad. Sci. U S A 93, 12251-12255.

Lowman, H.B., Bass, S.H., Simpson, N. and Wells, J.A. (1991) Selecting highaffinity binding proteins by monovalent phage display. Biochemistry 30, 1083210838 .

Lu, Z., Murray, K.S., Van Cleave, V., LaVallie, E.R., Stahl, M.L. and McCoy, J.M. (1995) Expression of thioredoxin random peptide libraries on the Escherichia coli cell surface as functional fusions to flagellin: a system designed for exploring proteinprotein interactions. Biotechnology 13, 366-372.

Lång, H. (2000) Outer membrane proteins as surface display systems. Int. J. Med. Microbiol. 290, 579-585.

Lång, H. and Korhonen, T.K. (1997) The OmpS maltoporin of Vibrio cholerae as carrier of foreign epitopes. Behring Inst. Mitt., 400-409.

Maggi, T., Spinosa, M., Ricci, S., Medaglini, D., Pozzi, G. and Oggioni, M.R. (2002) Genetic engineering of Streptococcus gordonii for the simultaneous display of two heterologous proteins at the bacterial surface. FEMS Microbiol. Lett. 210, 135-141. 
Malik, P., Terry, T.D., Bellintani, F. and Perham, R.N. (1998) Factors limiting display of foreign peptides on the major coat protein of filamentous bacteriophage capsids and a potential role for leader peptidase. FEBS Lett. 436, 263-266.

Maurer, J., Jose, J. and Meyer, T.F. (1997) Autodisplay: one-component system for efficient surface display and release of soluble recombinant proteins from Escherichia coli. J. Bacteriol.179, 794-804.

Mazmanian, S.K., Liu, G., Ton-That, H. and Schneewind, O. (1999) Staphylococcus aureus sortase, an enzyme that anchors surface proteins to the cell wall. Science 285, 760-763.

McCafferty, J., Griffiths, A.D., Winter, G. and Chiswell, D.J. (1990) Phage antibodies: filamentous phage displaying antibody variable domains. Nature 348, 552-554.

Medaglini, D., Pozzi, G., King, T.P. and Fischetti, V.A. (1995) Mucosal and systemic immune responses to a recombinant protein expressed on the surface of the oral commensal bacterium Streptococcus gordonii after oral colonization. Proc. Natl. Acad. Sci. USA. 92, 6868-6872.

Medaglini, D., Ciabattini, A., Spinosa, M.R., Maggi, T., Marcotte, H., Oggioni, M.R and Pozzi, G. (2001) Immunization with recombinant Streptococcus gordonii expressing tetanus toxin fragment $\mathrm{C}$ confers protection from lethal challenge in mice. (2001) Vaccine 19, 1931-1939

Mejáre, M. and Bülow, L. (2001) Metal-binding proteins and peptides in bioremediation and phytoremediation of heavy metals. Trends Biotechnol. 19, 67-73.

Mejáre, M., Ljung, S. and Bülow, L. (1998) Selection of cadmium specific hexapeptides and their expression as OmpA fusion proteins in Escherichia coli. Protein Eng. 11, 489-494.

Mekalanos, J.J. (1994) Live bacterial vaccines: environmental aspects. Curr. Opin. Biotechnol. 5, 312-319.

Mesnage, S., Weber-Levy, M., Haustant, M., Mock, M. and Fouet, A. (1999) Cell surface-exposed tetanus toxin fragment $\mathrm{C}$ produced by recombinant Bacillus anthracis protects against tetanus toxin. Infect. Immun. 67, 4847-4850.

Moks, T., Abrahmsén, L., Nilsson, B., Hellman, U., Sjöquist, J. and Uhlén, M. (1986) Staphylococcal protein A consists of five IgG-binding domains. Eur. J. Biochem. 156, 637-643.

Mullen, M.D., Wolf, D.C., Ferris, F.G., Beveridge, T.J., Flemming, C.A. and Bailey, G.W. (1989) Bacterial sorption of heavy metals. Appl. Environ. Microbiol. 55, 31433149 .

Nakajima, H., Shimbara, N., Shimonishi, Y., Mimori, T., Niwa, S. and Saya, H. (2000) Expression of random peptide fused to invasin on bacterial cell surface for selection of cell-targeting peptides. Gene 260, 121-131.

Navarre, W.W. and Schneewind, O. (1994) Proteolytic cleavage and cell wall anchoring at the LPXTG motif of surface proteins in gram-positive bacteria. Mol. Microbiol. 14, 115-121. 
Navarre, W.W. and Schneewind, O. (1999) Surface proteins of gram-positive bacteria and mechanisms of their targeting to the cell wall envelope. Microbiol. Mol. Biol. Rev. 63, 174-229.

Nguyen, T.N., Gourdon, M.H., Hansson, M., Robert, A., Samuelson, P., Libon, C., Andréoni, C., Nygren, P.-Å., Binz, H., Uhlén, M. and Ståhl, S. (1995) Hydrophobicity engineering to facilitate surface display of heterologous gene products on Staphylococcus xylosus. J. Biotechnol. 42, 207-219.

Nguyen, T.N., Hansson, M., Ståhl, S., Bachi, T., Robert, A., Domzig, W., Binz, H. and Uhlén, M. (1993) Cell-surface display of heterologous epitopes on Staphylococcus xylosus as a potential delivery system for oral vaccination. Gene 128, 89-94.

Nigam, J.N. (2000) Continuous ethanol production from pineapple cannery waste using immobilized yeast cells. J. Biotechnol. 80, 189-193.

Nilsson, B., Moks, T., Jansson, B., Abrahmsén, L., Elmblad, A., Holmgren, E., Henrichson, C., Jones, T.A. and Uhlén, M. (1987) A synthetic IgG-binding domain based on staphylococcal protein A. Protein Eng. 1, 107-113.

Nilsson, J., Ståhl, S., Lundeberg, J., Uhlén, M. and Nygren, P.-Å. (1997) Affinity fusion strategies for detection, purification, and immobilization of recombinant proteins. Protein Expr. Purif. 11, 1-16.

Nord, K., Gunneriusson, E., Ringdahl, J., Ståhl, S., Uhlén, M. and Nygren, P.-Å. (1997) Binding proteins selected from combinatorial libraries of an alpha-helical bacterial receptor domain. Nat. Biotechnol. 15, 772-777.

Nord, K., Nilsson, J., Nilsson, B., Uhlén, M. and Nygren, P.-Å. (1995) A combinatorial library of an alpha-helical bacterial receptor domain. Protein Eng. 8, 601-608.

Nord, K., Nord, O., Uhlén, M., Kelley, B., Ljungqvist, C. and Nygren, P.-Å. (2001) Recombinant human factor VIII-specific affinity ligands selected from phagedisplayed combinatorial libraries of protein A. Eur. J. Biochem. 268, 4269-4277.

Nygren, P.-Å. and Uhlén, M. (1997) Scaffolds for engineering novel binding sites in proteins. Curr. Opin. Struct. Biol. 7, 463-469.

Oggioni, M.R., Medaglini, D., Maggi, T. and Pozzi, G. (1999) Engineering the grampositive cell surface for construction of bacterial vaccine vectors. Methods 19, 163173.

Olsen, M., Iverson, B. and Georgiou, G. (2000a) High-throughput screening of enzyme libraries. Curr. Opin. Biotechnol. 11, 331-337.

Olsen, M.J., Stephens, D., Griffiths, D., Daugherty, P., Georgiou, G. and Iverson, B.L. (2000b) Function-based isolation of novel enzymes from a large library. Nat. Biotechnol. 18, 1071-1074.

Pagan, R., Manas, P., Raso, J. and Condon, S. (1999) Bacterial resistance to ultrasonic waves under pressure at nonlethal (manosonication) and lethal (manothermosonication) temperatures. Appl. Environ. Microbiol. 65, 297-300.

Patwardhan, A.V., Goud, G.N., Koepsel, R.R. and Ataai, M.M. (1997) Selection of optimum affinity tags from a phage-displayed peptide library. Application to immobilized copper (II) affinity chromatography. J. Chromatogr. A 787, 91-100. 
Pazirandeh, M. (1996) Development of a metallothionein based heavy metal biosorbent. Biochem. Mol. Biol. Int. 39, 789-795.

Pazirandeh, M., Chrisey, L.A., Mauro, J.M., Campbell, J.R. and Gaber, B.P. (1995) Expression of the Neurospora crassa metallothionein gene in Escherichia coli and its effect on heavy-metal uptake. Appl. Microbiol. Biotechnol. 43, 1112-1117.

Pazirandeh, M., Wells, B.M. and Ryan, R.L. (1998) Development of bacterium-based heavy metal biosorbents: enhanced uptake of cadmium and mercury by Escherichia coli expressing a metal binding motif. Appl. Environ. Microbiol. 64, 4068-4072.

Pereboeva, L.A., Pereboev, A.V., Wang, L.F. and Morris, G.E. (2000) Hepatitis C epitopes from phage-displayed cDNA libraries and improved diagnosis with a chimeric antigen. J. Med. Virol. 60, 144-151.

Piard, J.C., Hautefort, I., Fischetti, V.A., Ehrlich, S.D., Fons, M. and Gruss, A. (1997) Cell wall anchoring of the Streptococcus pyogenes M6 protein in various lactic acid bacteria. J. Bacteriol. 179, 3068-3072.

Pilkington, P.H., Margaritis, A. and Mensour, N.A. (1998) Mass transfer characteristics of immobilized cells used in fermentation processes. Crit. Rev. Biotechnol., 237-255.

Pozzi, G., Oggioni, M.R., Manganelli, R. and Fischetti, V.A. (1992) Expression of M6 protein gene of Streptococcus pyogenes in Streptococcus gordonii after chromosomal integration and transcriptional fusion. Res. Microbiol. 143, 449-457.

Rauser, W.E. (1995) Phytochelatins and related peptides. Structure, biosynthesis, and function. Plant Physiol. 109, 1141-1149.

Reinikainen, T., Teleman, O. and Teeri, T.T. (1995) Effects of pH and high ionic strength on the adsorption and activity of native and mutated cellobiohydrolase I from Trichoderma reesei. Proteins 22, 392-403.

Ribeiro, L.A., Azevedo, V., Le Loir, Y., Oliveira, S.C., Dieye, Y., Piard, J.C., Gruss, A. and Langella, P. (2002) Production and targeting of the Brucella abortus antigen L7/L12 in Lactococcus lactis: a first step towards food-grade live vaccines against brucellosis. Appl. Environ. Microbiol. 68, 910-916.

Robert, A., Samuelson, P., Andréoni, C., Bachi, T., Uhlén, M., Binz, H., Nguyen, T.N. and Ståhl, S. (1996) Surface display on staphylococci: a comparative study. FEBS Lett. 390, 327-333.

Rönnmark, J., Grönlund, H., Uhlén, M. and Nygren, P.-Å. (2002) Human immunoglobulin A (IgA)-specific ligands from combinatorial engineering of protein A. Eur. J. Biochem. 269, 2647-2655.

Ruiz-Perez, F., Leon-Kempis, R., Santiago-Machuca, A., Ortega-Pierres, G., Barry, E., Levine, M. and Gonzalez-Bonilla, C. (2002) Expression of the Plasmodium falciparum immunodominant epitope (NANP)(4) on the surface of Salmonella enterica using the autotransporter MisL. Infect. Immun. 70, 3611-3620.

Samuelson, P., Cano, F., Robert, A. and Ståhl, S. (1999) Engineering of a Staphylococcus carnosus surface display system by substitution or deletion of a Staphylococcus hyicus lipase propeptide. FEMS Microbiol. Lett. 179, 131-139.

Samuelson, P., Gunneriusson, E., Nygren, P.-Å. and Ståhl, S. (2002) Display of proteins on bacteria. J. Biotechnol. 96, 129-154. 
Samuelson, P., Hansson, M., Ahlborg, N., Andréoni, C., Götz, F., Bachi, T., Nguyen, T.N., Binz, H., Uhlén, M. and Ståhl, S. (1995) Cell surface display of recombinant proteins on Staphylococcus carnosus. J. Bacteriol. 177, 1470-1476.

Schembri, M.A., Kjaergaard, K. and Klemm, P. (1999) Bioaccumulation of heavy metals by fimbrial designer adhesins. FEMS Microbiol. Lett. 170, 363-371.

Schleifer, K.H. and Fischer, U. (1982) Description of a new species of the genus Staphylococcus. Staphylococcus carnosus. Int. J. Syst. Bacteriol. 32, 153-156.

Schleifer, K.H. and Kloos, W.E. (1975) A simple test system for the separation of staphylococci from micrococci. J. Clin. Microbiol. 1, 337-338.

Schnappinger, D., Geissdorfer, W., Sizemore, C. and Hillen, W. (1995) Extracellular expression of native human anti-lysozyme fragments in Staphylococcus carnosus. FEMS Microbiol. Lett. 129, 121-127.

Schneewind, O., Fowler, A. and Faull, K.F. (1995) Structure of the cell wall anchor of surface proteins in Staphylococcus aureus. Science 268, 103-106.

Schorr, J., Knapp, B., Hundt, E., Kupper, H.A. and Amann, E. (1991) Serum expression of malarial antigens in Salmonella typhimurium: induction of serum antibody response upon oral vaccination of mice. 9, 675-681.

Schreuder, M.P., Mooren, A.T., Toschka, H.Y., Verrips, C.T. and Klis, F.M. (1996) Immobilizing proteins on the surface of yeast cells. Trends Biotechnol. 14, 115-120.

Scouten, W.H. (1995) Matrices and activation methods for cell adhesion/immobilization studies. Bioprocess Technol. 20, 233-265.

Shapiro, H.M. (1995) Practical flow cytometry. Wiley-Liss, New York.

Shi, H. and Wen Su, W. (2001) Display of green fluorescent protein on Escherichia coli cell surface. Enzyme Microb. Technol. 28, 25-34.

Shimazu, M., Mulchandani, A. and Chen, W. (2001) Cell surface display of organophosphorus hydrolase using ice nucleation protein. Biotechnol. Prog. 17, 7680 .

Skerra, A. (2000) Engineered protein scaffolds for molecular recognition. J. Mol. Recognit. 13, 167-187.

Smith, G.P. (1985) Filamentous fusion phage: novel expression vectors that display cloned antigens on the virion surface. Science 228, 1315-1317.

Smith, G.P. and Petrenko, V.A. (1997) Phage Display. Chem. Rev. 97, 391-410.

Sousa, C., Cebolla, A. and de Lorenzo, V. (1996) Enhanced metalloadsorption of bacterial cells displaying poly-His peptides. Nat. Biotechnol. 14, 1017-1020.

Sousa, C., Kotrba, P., Ruml, T., Cebolla, A. and De Lorenzo, V. (1998) Metalloadsorption by Escherichia coli cells displaying yeast and mammalian metallothioneins anchored to the outer membrane protein LamB. J. Bacteriol. 180, 2280-2284.

Ståhl, S., Robert, A., Gunneriusson, E., Wernérus, H., Cano, F., Liljeqvist, S., Hansson, M., Nguyen, T.N. and Samuelson, P. (2000) Staphylococcal surface display and its applications. Int. J. Med. Microbiol. 290, 571-577. 
Ståhl, S., Samuelson, P., Hansson, M., Andréoni, C., Goetsch, L., Libon, C., Liljeqvist, S., Gunneriusson, E., Binz, H., Nguyen, N. and Uhlén, M. (1997) Development of non-pathogenic staphylococci as vaccine delivery vehicles. In: G. Pozzi and J. Wells (Eds), Gram-Positive Bacteria: Vaccine vehicles for Mucosal Immunization. Landes Bioscience, Georgetown, TX, p. 62-81.

Ståhl, S. and Uhlén, M. (1997) Bacterial surface display: trends and progress. Trends Biotechnol. 15, 185-192.

Stathopoulos, C. (1999) Bacterial outer membrane proteins: topological analyses and biotechnological perspectives. Membr. Cell Biol. 13, 3-21.

Stathopoulos, C., Georgiou, G. and Earhart, C.F. (1996) Characterization of Escherichia coli expressing an Lpp'OmpA(46-159)-PhoA fusion protein localized in the outer membrane. Appl. Microbiol. Biotechnol. 45, 112-119.

Steidler, L., Viaene, J., Fiers, W. and Remaut, E. (1998) Functional display of a heterologous protein on the surface of Lactococcus lactis by means of the cell wall anchor of Staphylococcus aureus protein A. Appl. Environ. Microbiol. 64, 342-345.

Stemmer, W.P. (1994a) DNA shuffling by random fragmentation and reassembly: in vitro recombination for molecular evolution. Proc. Natl. Acad. Sci. U S A 91, 1074710751.

Stemmer, W.P. (1994b) Rapid evolution of a protein in vitro by DNA shuffling. Nature 370, 389-391.

Stillman, M.J., Shaw, F.C.I. and Suzuki, K.T. (1992) Metallothioneins. VCH Publishers, Berlin.

Stover, C.K., Bansal, G.P., Hanson, M.S., Burlein, J.E., Palaszynski, S.R., Young, J.F., Koenig, S., Young, D.B., Sadziene, A. and Barbour, A.G. (1993) Protective immunity elicited by recombinant bacille Calmette-Guerin (BCG) expressing outer surface protein A (OspA) lipoprotein: a candidate Lyme disease vaccine. J. Exp. Med. 178, 197-209.

Strauss, A. and Götz, F. (1996) In vivo immobilization of enzymatically active polypeptides on the cell surface of Staphylococcus carnosus. Mol. Microbiol. 21, 491500 .

Strauss, A., Thumm, G. and Götz, F. (1998) Influence of Lif, the lysostaphin immunity factor, on acceptors of surface proteins and cell wall sorting efficiency in Staphylococcus carnosus. J. Bacteriol. 180, 4960-4962.

Taschner, S., Meinke, A., Von Gabain, A. and Boyd, A.P. (2002) Selection of Peptide Entry Motifs by Bacterial Surface Display. Biochem. J. 26.

Tomme, P., Boraston, A., McLean, B., Kormos, J., Creagh, A.L., Sturch, K., Gilkes, N.R., Haynes, C.A., Warren, R.A. and Kilburn, D.G. (1998) Characterization and affinity applications of cellulose-binding domains. J. Chromatogr. B. Biomed. Sci. Appl. 715, 283-296.

Ton-That, H., Liu, G., Mazmanian, S.K., Faull, K.F. and Schneewind, O. (1999) Purification and characterization of sortase, the transpeptidase that cleaves surface proteins of Staphylococcus aureus at the LPXTG motif. Proc. Natl. Acad. Sci. U S A 96, 12424-12429. 
Ton-That, H., Mazmanian, S.K., Faull, K.F. and Schneewind, O. (2000) Anchoring of surface proteins to the cell wall of Staphylococcus aureus. Sortase catalyzed in vitro transpeptidation reaction using LPXTG peptide and NH(2)-Gly(3) substrates. J. Biol. Chem. 275, 9876-9881.

Tripp, B.C., Lu, Z., Bourque, K., Sookdeo, H. and McCoy, J.M. (2001) Investigation of the 'switch-epitope' concept with random peptide libraries displayed as thioredoxin loop fusions. Protein Eng. 14, 367-377.

Uhlén, M., Guss, B., Nilsson, B., Gatenbeck, S., Philipson, L. and Lindberg, M. (1984) Complete sequence of the staphylococcal gene encoding protein A. A gene evolved through multiple duplications. J. Biol. Chem. 259, 1695-1702.

Valls, M., Atrian, S., de Lorenzo, V. and Fernandez, L.A. (2000a) Engineering a mouse metallothionein on the cell surface of Ralstonia eutropha $\mathrm{CH} 34$ for immobilization of heavy metals in soil. Nat. Biotechnol. 18, 661-665.

Valls, M., de Lorenzo, V., Gonzalez-Duarte, R. and Atrian, S. (2000b) Engineering outer-membrane proteins in Pseudomonas putida for enhanced heavy-metal bioadsorption. J. Inorg. Biochem. 79, 219-223.

Valls, M., Gonzalez-Duarte, R., Atrian, S. and De Lorenzo, V. (1998) Bioaccumulation of heavy metals with protein fusions of metallothionein to bacterial OMPs. Biochimie 80, 855-861.

van Die, I., van Oosterhout, J., van Megen, I., Bergmans, H., Hoekstra, W., EngerValk, B., Barteling, S. and Mooi, F. (1990) Expression of foreign epitopes in Pfimbriae of Escherichia coli. Mol. Gen. Genet. 222, 297-303.

Wang, A.A., Mulchandani, A. and Chen, W. (2001) Whole-cell immobilization using cell surface-exposed cellulose-binding domain. Biotechnol. Prog. 17, 407-411.

Wang, A.A., Mulchandani, A. and Chen, W. (2002) Specific adhesion to cellulose and hydrolysis of organophosphate nerve agents by a genetically engineered Escherichia coli strain with a surface-expressed cellulose-binding domain and organophosphorus hydrolase. Appl. Environ. Microbiol. 68, 1684-1689.

Watson, J.V. and Dive, C. (1994) Enzyme kinetics. Methods Cell Biol 41, 469-507.

Wells, J. and Pozzi, G. (1997) An overview of Gram-positive bacteria as vaccine vehicles for mucosal imunizations. In: G. Pozzi and J. Wells (Eds), Gram-Positive Bacteria: Vaccine vehicles for Mucosal Immunization. Landes Bioscience, Georgetown, TX, p. 1-8.

Wentzel, A., Christmann, A., Adams, T. and Kolmar, H. (2001) Display of passenger proteins on the surface of Escherichia coli K-12 by the enterohemorrhagic E. coli intimin EaeA. J. Bacteriol. 183, 7273-7284.

Westerlund-Wikström, B. (2000) Peptide display on bacterial flagella: principles and applications. Int. J. Med. Microbiol. 290, 223-230.

Whitehorn, E.A., Tate, E., Yanofsky, S.D., Kochersperger, L., Davis, A., Mortensen, R.B., Yonkovich, S., Bell, K., Dower, W.J. and Barrett, R.W. (1995) A generic method for expression and use of "tagged" soluble versions of cell surface receptors. Biotechnology (N Y) 13, 1215-1219. 
Wieland, K.P., Wieland, B. and Götz, F. (1995) A promoter-screening plasmid and xylose-inducible, glucose-repressible expression vectors for Staphylococcus carnosus. Gene 158, 91-96.

Williams, R.J., Nair, S.P., Henderson, B., Holland, K.T. and Ward, J.M. (2002) Expression of the $S$. aureus hysA gene in $S$. carnosus from a modified E. colistaphylococcal shuttle vector. Plasmid 47, 241-245.

Wittrup, K.D. (2001) Protein engineering by cell-surface display. Curr. Opin. Biotechnol. 12, 395-399.

Wobler, P.K. (1993) Bacterial ice nucleation. Adv. Microb. Physiol. 34, 203-235.

Wong, R.S., Wirtz, R.A. and Hancock, R.E. (1995) Pseudomonas aeruginosa outer membrane protein OprF as an expression vector for foreign epitopes: the effects of positioning and length on the antigenicity of the epitope. Gene 158, 55-60.

$\mathrm{Xu}, \mathrm{Z}$. and Lee, S.Y. (1999) Display of polyhistidine peptides on the Escherichia coli cell surface by using outer membrane protein $\mathrm{C}$ as an anchoring motif. Appl. Environ. Microbiol. 65, 5142-5147. 